BMI/OTSP--07

DE90 000588

\title{
MRS Systems Study, Task F: Transportation Impacts of a Monitored Retrievable Storage Facility
}

This document is

PUPLICLY RLEASABLE

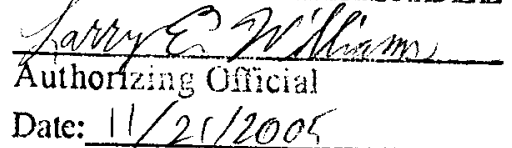

Technical Report

May 1989

L. A. Brentlinger

S. Gupta*

A. M. Plummer

L. A. Smith

S. Tzemos

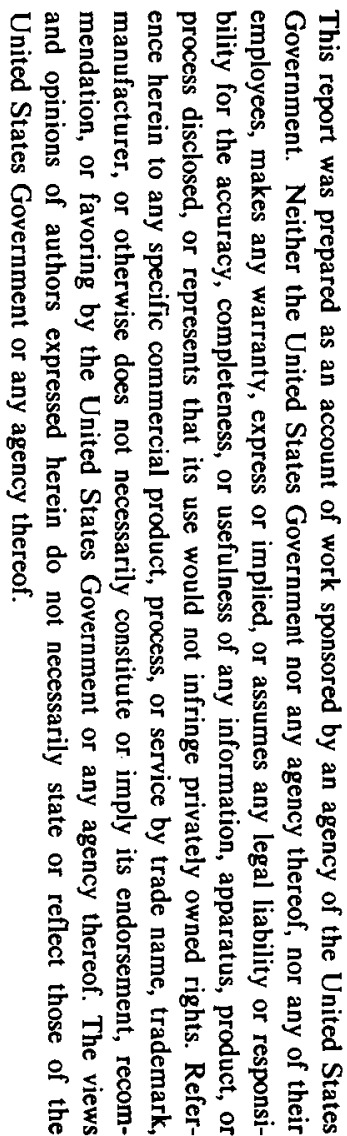

${ }^{*}$ Currently with ICF, Incorporated.

Office of Transportation Systems and Planning Battelle Nuclear Systems Group 505 King Avenue Columbus, Ohio $43201-2693$

The content of this report was effective as of April 1989. This report was prepared by Battelle Nuclear Systems Group, Columbus, OH, under Contract No. DE-AC02-83CH10139 with the U.S. Department of Energy. 


\section{DISCLAIMER}

This report was prepared as an account of work sponsored by an agency of the United States Government. Neither the United States Government nor any agency Thereof, nor any of their employees, makes any warranty, express or implied, or assumes any legal liability or responsibility for the accuracy, completeness, or usefulness of any information, apparatus, product, or process disclosed, or represents that its use would not infringe privately owned rights. Reference herein to any specific commercial product, process, or service by trade name, trademark, manufacturer, or otherwise does not necessarily constitute or imply its endorsement, recommendation, or favoring by the United States Government or any agency thereof. The views and opinions of authors expressed herein do not necessarily state or reflect those of the United States Government or any agency thereof. 


\section{DISCLAIMER}

Portions of this document may be illegible in electronic image products. Images are produced from the best available original document. 


\section{ABSTRACT}

The passage of the Nuclear Waste Policy Amendments Act of 1987 (NWPAA) modified the basis from which the Office of Civilian Radioactive Waste Management (OCRWM) had derived and developed the configuration of major elements of the waste system (repository, monitored retrievable storage, and transportation). While the key aspects of the Nuclear waste Policy Act of 1982 remain unaltered, NWPAA provisions focusing site characterization solely at Yucca Mountain, authorizing a monitored retrievable storage (MRS) facility with specific linkages to the repository, and establishing an MRS Review Commission make it prudent for OCRWM to update its analysis of the role of the MRS in the overall waste system configuration.

This report documents the differences in transportation costs and radiological dose under alternative scenarios pertaining to a nuclear waste management system with and without an MRS, to include the effect of various MRS packaging functions and locations. The analysis is limited to the impacts of activities related directly to the hauling of high-level radioactive waste $(H L W)$, including the capital purchase and maintenance costs of the transportation cask system. Loading and unloading impacts are not included in this study because they are treated as facility costs in the other task reports. Transportation costs are based on shipments of 63,000 metric tons of uranium (MTU) of spent nuclear fuel and 7,000 MTU equivalent of HLW. 
FOREWORD

The National Waste Terminal Storage Program was established in 1976 by the U.S. Energy Research and Development Administration. In September 1983, this program became the Civilian Radioactive Waste Management Program. Its purpose is to develop technology and provide facilities for safe, environmentally acceptable, permanent disposal of high-level waste (HLW). HLW includes wastes from both commercial and defense sources, such as spent (used) fuel from nuclear power reactors, accumulations of wastes from production of nuclear weapons, and solidified wastes from fuel processing.

The information in this report pertains to the monitored retrievable storage system studies of the Office of Systems Integration and Regulations of the Office of Civilian Radioactive Waste Management. 
TABLE OF CONTENTS

$\underline{\text { Page }}$

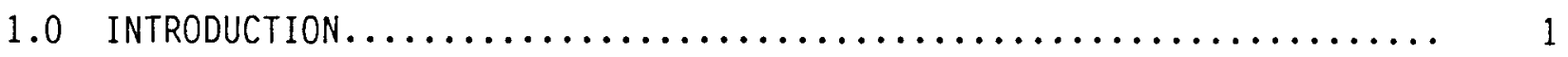

2.0 OBJECTIVES AND SCOPE OF STUDY.......................... 3

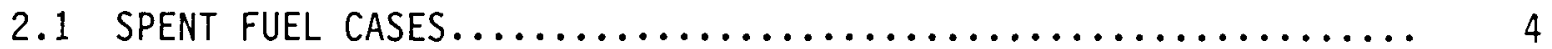

2.2 HIGH-LEVEL WASTE CASES $\ldots \ldots \ldots \ldots \ldots \ldots \ldots \ldots \ldots \ldots \ldots \ldots \ldots, 6 \ldots \ldots, \ldots \ldots \ldots$

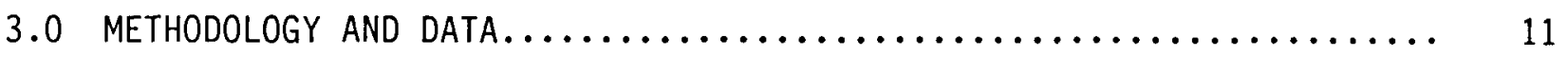

3.1 COST AND DOSE DATA $\ldots \ldots \ldots \ldots \ldots \ldots \ldots \ldots \ldots \ldots \ldots \ldots \ldots \ldots \ldots \ldots \ldots \ldots, 11$

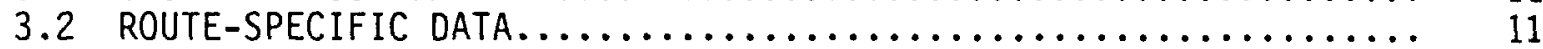

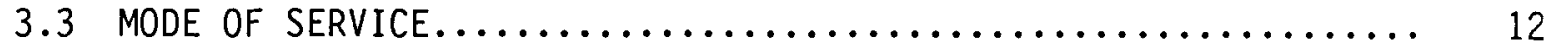

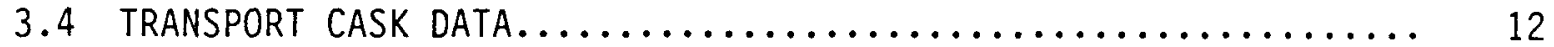

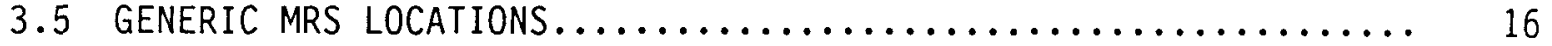

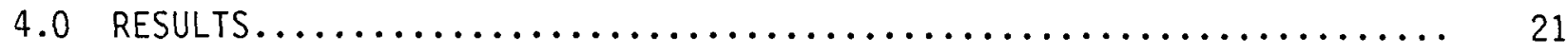

4.1 SPENT FUEL CASES $\ldots \ldots \ldots \ldots \ldots \ldots \ldots \ldots \ldots \ldots \ldots, \ldots \ldots \ldots, 21$

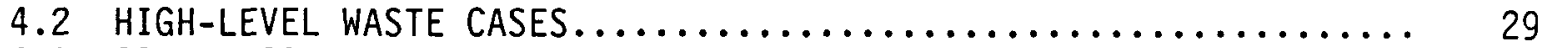

4.3 COMPARISON WITH PREVIOUS DOE ANALYSES $\ldots \ldots \ldots \ldots \ldots \ldots \ldots \ldots \ldots, 30$

4.3 .1 No-MRS System................................ 30

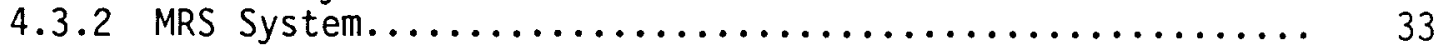

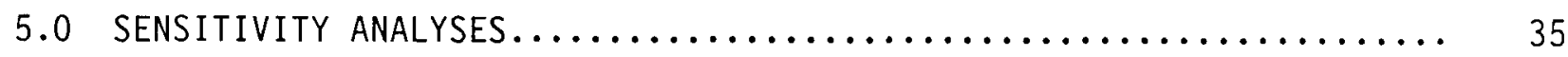

5.1 SENSITIVITY ANALYSIS - SIX MRS CENTROID LOCATIONS........... 35

5.2 SENSITIVITY ANALYSIS - MINIMUM SHIPMENT-MILE LOCATION......... 43

5.3 SENSITIVITY ANALYSIS - OVERWEIGHT TRUCK.................. 48

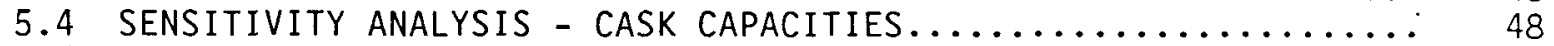

5.5 SENSITIVITY ANALYSIS - TRANSPORTABLE STORAGE CASK............ 51

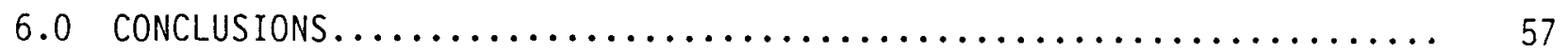

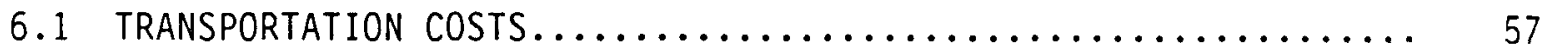

6.2 TRANSPORTATION DOSE...................................... 59

6.3 TRANSPORTATION NONRADIOLOGICAL RISK.................... 60

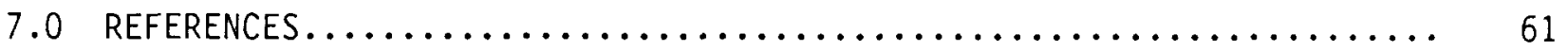

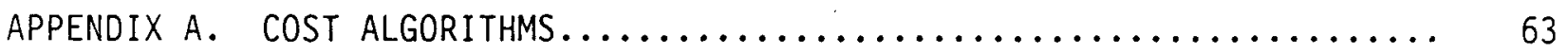

A.1 ANNUAL SHIPPING COSTS.......................... 65

A.2 ACCUMULATED ANNUAL COSTS $\ldots \ldots \ldots \ldots \ldots \ldots \ldots \ldots \ldots \ldots \ldots \ldots$

APPENDIX B. GENERIC MRS ROUTE AVERAGING METHOD.................. 71

APPENDIX C. TRICAM: THE TRANSPORTATION RISK AND COST ANALYSIS MODEL

FOR THE CIVILIAN RADIOACTIVE WASTE MANAGEMENT PROGRAM....... 79 


\section{LIST OF TABLES}

Title $\quad$ Page

Table 1. Spent Fuel Cases............................. 5

Table 2. Spent Fuel Acceptance Schedule for No-MRS System (Network 1)... 7

Table 3. Spent Fuel Acceptance Schedule for No-Western Strategy Cases

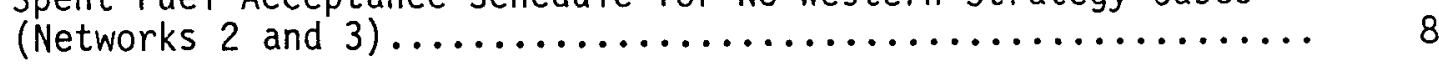

Table 4. Spent Fuel Acceptance Schedule for Western-Strategy Cases

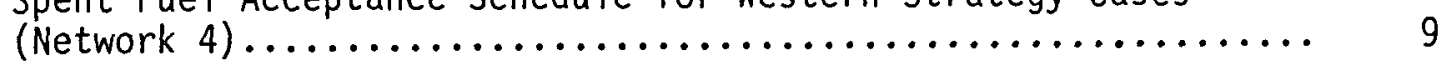

Table 5. High-Level Waste Acceptance and Shipment Schedule.......... 10

Table 6. Mode of Service at Reactors in the EIA No-New-Orders

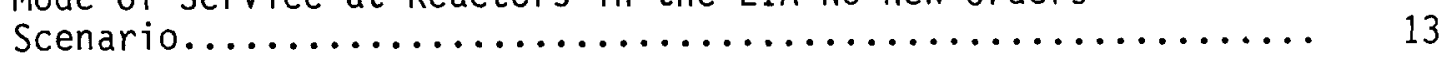

Table 7. Cask Systems Used in the Transportation Analysis........... 16

Table 8. Cask Systems Used for Shipments From MRS to Repository....... 17

Table 9. Data for Casks Used in Shipments From Waste Generators to

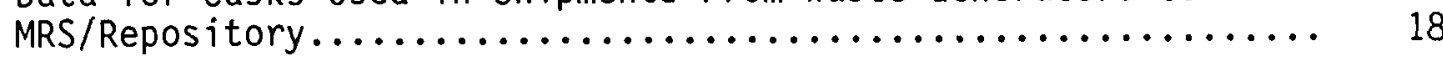

Table 10. Data for Rail Casks Used in Shipments From MRS to Repository... 19

Table 11. Six Regions and Their Centroids.................... 20

Table 12. Summary of Life-Cycle Transportation Cost and Dose for 24-Year Shipping Campaign (Spent Fuel Cases)...................... 22

Table 13. Summary of Life-Cycle Transportation Cost and Dose by MRS Location for 24-Year Shipping Campaign (Spent Fuel Cases)..... 22

Table 14. Measures of Life-Cycle Transportation Impacts for 24-Year

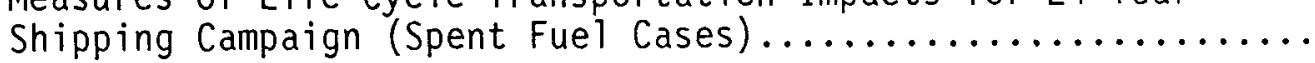

Table 15. Life-Cycle Cost by Transportation Link (\$millions) for 24-Year

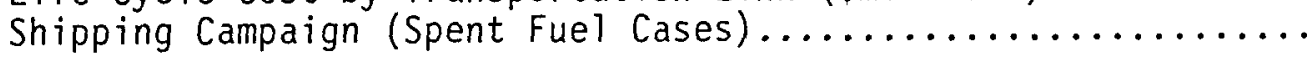

Table 16. Dose by Transportation Link for $(1,000$ s person-rem) for

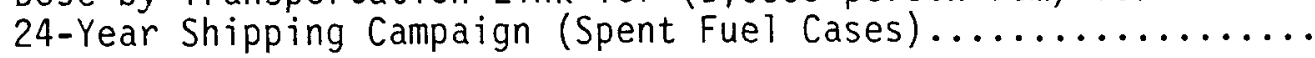

Table 17. Number of Shipments by Transportation Link for 24-Year

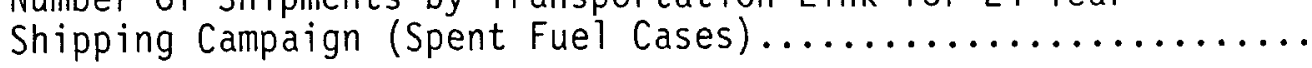

Table 18. Shipment-Miles by Transportation Link $(1,000 \mathrm{~s})$ for 24-Year

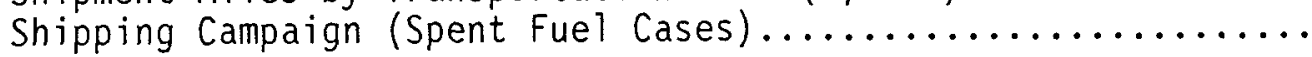

Table 19. Cask-Miles by Transportation Link $(1,000 \mathrm{~s})$ for 24-Year

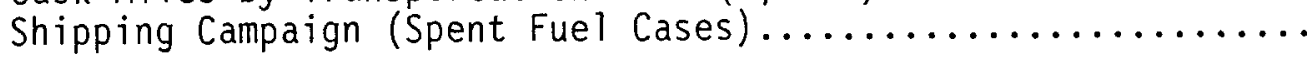




\section{LIST OF TABLES \\ (continued)}

\section{Title}

$\underline{\text { Page }}$

Table 20. MTU-Miles by Transportation Link (1,000s) for 24-Year

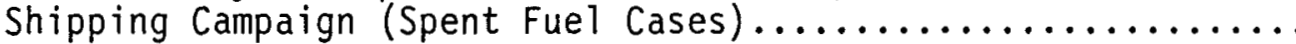

Table 21. Transportation Life-Cycle Cost and Measures of Activity -

High-Leve 1 Waste Cases............................. 31

Table 22. Distances (Miles) From High-Level Waste Sites............ 32

Table 23. Summary of Transportation Cost and Dose by MRS Location -

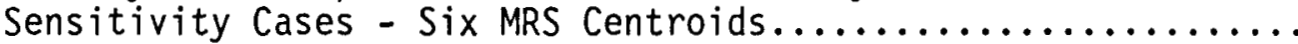

Table 24. Measures of Transportation Activity - Sensitivity Cases - Six

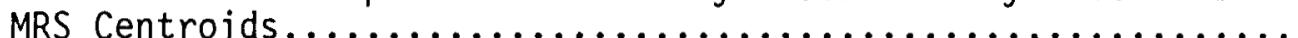

Table 25. Cost by Transportation Link (\$millions) - Sensitivity

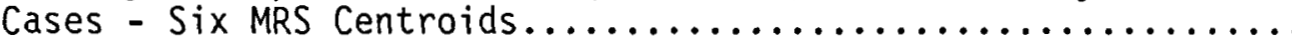

Table 26. Dose by Transportation Link (1,000s person-rem) - Sensitivity Cases - Six MRS Centroids.

Table 27. Shipment-Miles by Transportation Link (1,000s) - Sensitivity

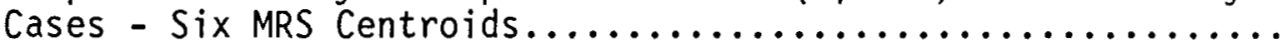

Table 28. Cask-Miles by Transportation Link (1,000s) - Sensitivity

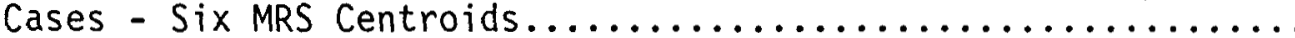

Table 29. MTU-Miles by Transportation Link (1,000s) - Sensitivity

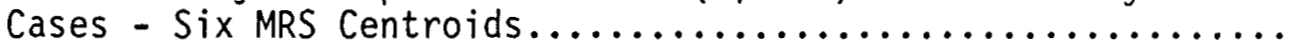

Table 30. Cost by Transportation Link (\$ millions) - Minimum Shipment-Miles MRS Location - Spent Fuel Cases...............

Table 31. Number of Shipments by Transportation Link - Minimum Shipment-Miles MRS Location - Spent Fuel Cases................

Table 32. Shipment-Miles by Transportation Link $(1,000 \mathrm{~s})$ Minimum Shipment-Miles MRS Location - Spent Fuel Cases.........

Table 33. Cask-Miles by Transportation Link (1,000s) Minimum Shipment-Miles MRS Location - Spent Fuel Cases.........

Table 34. Transportation Cost, Dose, and Measures of Activity -

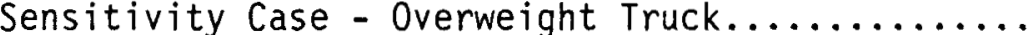

Table 35. From-Reactor Cask Capacity Used for Sensitivity Analysis...... 50

Table 36. From-MRS Cask Capacity Used for Sensitivity Analysis......... 50 
LIST OF TABLES

(cont inued)

\section{Title}

Page

Table 37. Summary of Transportation Costs and Doses for Reference,

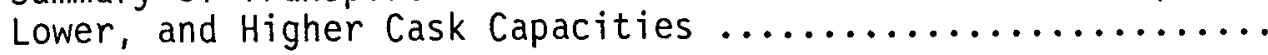

Table 38. Cost by Transportation Link ( $\$$ millions) - Reactors to

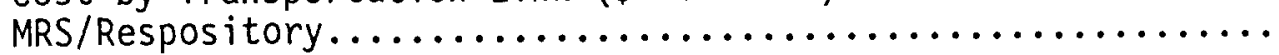

Table 39. Cost by Transportation Link ( $\$$ millions) - MRS to

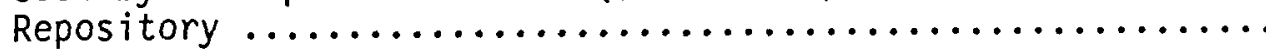

Table 40. Risk by Transportation Link (1,000 person-rem) -

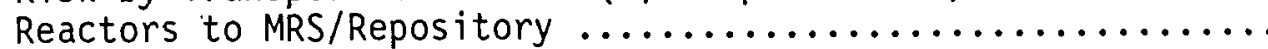

Table 41. Risk by Transportation Link (1,000 person-rem) - MRS to Repository

\section{LIST OF FIGURES}

Title

Figure 1. Schematic of Spent Fuel Cases...................... 5

Figure 2. The Six MRS Regional Centroids..................... 20

Figure B-1. Example of the TRICAM Route Links for a Route Transversing

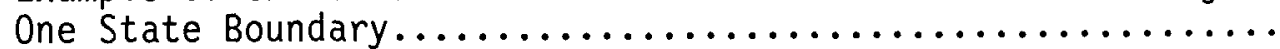

Figure B-2. Example of the TRICAM Route Links for a Route Transversing One State Boundary and Three Population Zones.............. 74

Figure B-3. Example of the TRICAM Route Links for Two Routes Transversing

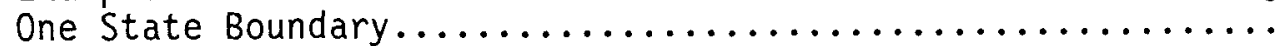

Figure B-4. Example of the TRICAM Route Links for Two Routes Transversing One State Boundary and Three Population Zones............... 


\subsection{INTRODUCTION}

The passage of the Nuclear Waste Policy Amendments Act of 1987 (NWPAA) modified the basis from which the Office of Civilian Radioactive Waste Management (OCRWM) had derived and developed the configuration of major elements of the waste system (repository, monitored retrievable storage, and transportation). While the key aspects of the Nuclear Waste Policy Act of 1982 remain unaltered, NWPAA provisions focusing site characterization solely at Yucca Mountain, authorizing a monitored retrievable storage (MRS) facility with specific linkages to the repository, and establishing an MRS Review Commission, make it prudent for OCRWM to update its analysis of the role of the MRS in the overall waste system configuration.

The scope of this update is described in the "Action Plan for Systems Study to Support the MRS Commission" (Ref. 1). The Action Plan outlined 10 tasks (Tasks A through $\mathrm{J}$ ), which together comprise the MRS Systems Study.

Chapter 2 defines the objectives and scope of the transportation analysis, including a definition of the spent fuel and high-level waste cases examined and reported in the study. Chapter 3 describes the methodology and data used. The results are presented in Chapter 4 with several sensitivity analyses described in Chapter 5. The conclusions drawn from the transportation analysis are presented in Chapter 6 . Chapter 7 lists the references. Supplementary information and detailed results are presented in appendices. 


\subsection{OBJECTIVE AND SCOPE OF STUDY}

The objective of this report is to document the differences in transportation costs and radiological dose under alternative scenarios pertaining to a nuclear waste management system with and without an MRS, to include the effect of various MRS packaging functions and locations. The analysis is limited to the impacts of activities related directly to the hauling of high-level radioactive waste (HLW), including the capital purchase and maintenance costs of the transportation cask system. Loading and unloading impacts are not included in this study because they are treated as facility costs in the other task reports. As prescribed in the Task A Report (Ref. 2), this study assumed that 63,000 metric tons of uranium (MTU) of spent fuel (SF) and 7,000 MTU of HLW are to be transported.

The Task A report identified several parameters that impact at least one of the system elements. Of these, the following parameters impact transportation and are considered in the present study:

1. The configuration of the Federal Waste Management System (FWMS).

Two basic FWMS configurations are considered in the following analysis:

- FWMS without an MRS (base case)

- FWMS with an MRS

The analyses in this report assume that given an FWMS with an MRS, all spent fuel and HLW are processed through the MRS facility (the exception being an MRS system with a Western strategy as described in number 4 below).

\section{Alternative MRS functions.}

The need for an MRS facility may depend on the functions it performs as part of an FWMS. Four alternative MRS packaging functions were identified in the Task A Report. These four functions, listed below, are the basis for evaluation of every FWMS element, including Transportation:

- Store Only: Storing the waste for subsequent shipment to the repository in larger rail casks

- Consolidate and Canister: Consolidating SF and loading it into canisters that are placed into a final disposal container at the repository

- Containerize Intact SF: Loading SF into disposal containers, in the form received, i.e., intact assemblies

- Consolidate and Containerize: Consolidating SF and loading it into disposal containers. 


\section{Alternative MRS Locations.}

The Task A report specified that in order to evaluate the effect of location on MRS evaluation, transportation impacts were to be calculated for two geographically diverse generic locations, representative of an Eastern and a Western MRS.

\section{Shipment strategy for fuel from Western reactorsl.}

When an MRS is included, Eastern reactors are assumed to ship all their fuel through the MRS, regardless of MRS 10cation. But, when an Eastern MRS is involved, it may be efficient in some cases to ship fuel from Western reactors directly to the repository. Therefore, alternative strategies for the Western fuel shipments are considered as follows:

- Shipments through the MRS, en route to the repository

- Shipments directly to the repository.

\subsection{SPENT FUEL CASES}

Eleven basic cases were used to characterize the impacts of spent fuel transportation, as depicted in Table 1. Figure 1 displays these eleven cases as a tree-diagram.

Note that four transportation networks (i.e., sets of origin-destination pairs) are implicit in these eleven cases:

1. All reactors shipping to the repository.

2. All reactors shipping to the generic Eastern MRS.

3. All reactors shipping to the generic Western MRS.

4. Western reactors shipping directly to the repository and the remaining reactors shipping to the generic Eastern MRS.

1 Western reactors are defined in the Task A Report as those located west of 100 degrees longitude. Twelve reactors fall in this category under the Energy Information Administration (EIA) No-New-Orders scenario:

Palo Verde 1

Palo Verde 2

Palo Verde 3

San Onofre 1

San Onofre 2

San Onofre 3

Diablo Canyon 1

Diablo Canyon 2

Rancho Seco

Humboldt Bay

Trojan

Washington Nuclear 2 
Table 1. Spent Fuel Cases

\begin{tabular}{|c|c|c|c|c|}
\hline & $\begin{array}{c}\text { MRS } \\
\text { Function }\end{array}$ & $\begin{array}{c}\text { MRS } \\
\text { Location }\end{array}$ & $\begin{array}{l}\text { Destination of } \\
\text { From Eastern } \\
\text { Reactors }\end{array}$ & $\begin{array}{l}\text { Spent Fuel } \\
\text { From Western } \\
\text { Reactors }\end{array}$ \\
\hline 1. & No-MRS & --- & Repository & Repository \\
\hline $\begin{array}{l}2 . \\
3 . \\
4 .\end{array}$ & $\begin{array}{l}\text { Store only } \\
\text { Store Only } \\
\text { Store Only }\end{array}$ & $\begin{array}{l}\text { East } \\
\text { East } \\
\text { West }\end{array}$ & $\begin{array}{l}\text { MRS } \\
\text { MRS } \\
\text { MRS }\end{array}$ & $\begin{array}{l}\text { MRS } \\
\text { Repository } \\
\text { MRS }\end{array}$ \\
\hline $\begin{array}{l}5 . \\
6 . \\
7 .\end{array}$ & $\begin{array}{l}\text { Consolidate \& Canister } \\
\text { Consolidate \& Canister } \\
\text { Consolidate \& Canister }\end{array}$ & $\begin{array}{l}\text { East } \\
\text { East } \\
\text { West }\end{array}$ & $\begin{array}{l}\text { MRS } \\
\text { MRS } \\
\text { MRS }\end{array}$ & $\begin{array}{l}\text { MRS } \\
\text { Repository } \\
\text { MRS }\end{array}$ \\
\hline $\begin{array}{l}8 . \\
9 .\end{array}$ & $\begin{array}{l}\text { Containerize Intact SF } \\
\text { Containerize Intact SF }\end{array}$ & $\begin{array}{l}\text { East } \\
\text { West }\end{array}$ & $\begin{array}{l}\text { MRS } \\
\text { MRS }\end{array}$ & $\begin{array}{l}\text { MRS* } \\
\text { MRS* }\end{array}$ \\
\hline $\begin{array}{l}10 . \\
11\end{array}$ & $\begin{array}{l}\text { Consolidate \& Containerize } \\
\text { Consolidate \& Containerize }\end{array}$ & $\begin{array}{l}\text { East } \\
\text { West }\end{array}$ & $\begin{array}{l}\text { MRS } \\
\text { MRS }\end{array}$ & $\begin{array}{l}\text { MRS* } \\
\text { MRS* }\end{array}$ \\
\hline
\end{tabular}

*When the MRS function is to containerize SF and HLW, it is assumed that the repository would not have containerization capability and therefore, fuel from all waste sources would be processed through the MRS.

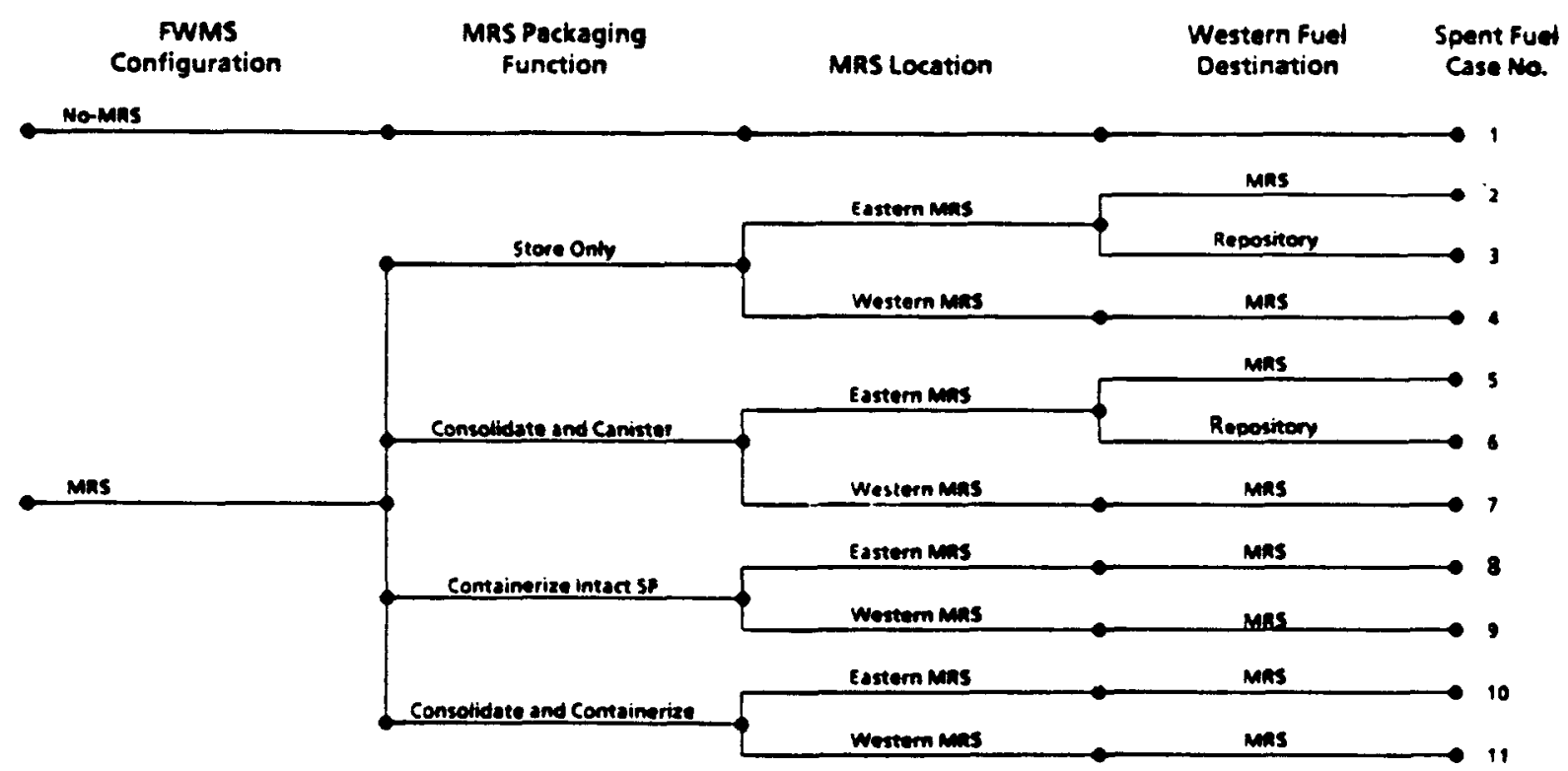

Figure 1. Schematic of Spent Fuel Cases 
Network 4 is referred to as the Western strategy. (Note that the Western strategy applies only when the MRS is in the East.) For convenience, the other networks are referred to as no-Western strategy.

The MRS Systems Study assumptions specify that shipments from reactors are to be scheduled according to the oldest-fuel-first (OFF) shipping rule. Another assumption is that transportation costs do not recognize inflation. Together, these two assumptions imply that transportation impacts for this study are independent of facility startup dates, within a given set of parameters (i.e., system configuration, MRS function, MRS location, and Western strategy). This is because, although the timing of shipments could vary for different facility startup. schedules, the total quantity shipped from individual reactors would not. And if the same quantities are shipped over the same network, then the inflated costs will not change.

Therefore, the transportation impacts can be calculated for one facility/ startup combination as well as for other combinations being examined in the MRS systems Study. For simplicity, concurrent MRS and repository startups are used in this study (see Tables 2 through 4 ). These tables show the SF quantities to be shipped annually under the No-MRS system, the No-Western-strategy, and the Western-strategy cases, respectively.

\subsection{HIGH-LEVEL WASTE CASES}

Three cases are sufficient to characterize the transportation impacts for HLW:

- HLW shipped through an Eastern MRS

- HLW shipped through a Western MRS

- HLW shipped directly to the repository.

The study specifications call for shipment of 7,000 MTU of HLW from West Valley and the three defense sites, which include Hanford, Savannah River, and the Idaho Chemical Processing Plant (ICPP). This quantity is to be shipped according to a set schedule, over 18 years. The acceptance and shipment schedules are shown in Table 5. Again, note that the transportation impacts calculated for this schedule are directly applicable to the variety of the facility startup dates being examined under the other Tasks of the MRS System Study. 
Table 2. Spent Fuel Acceptance Schedule for No-MRS System (Network 1)

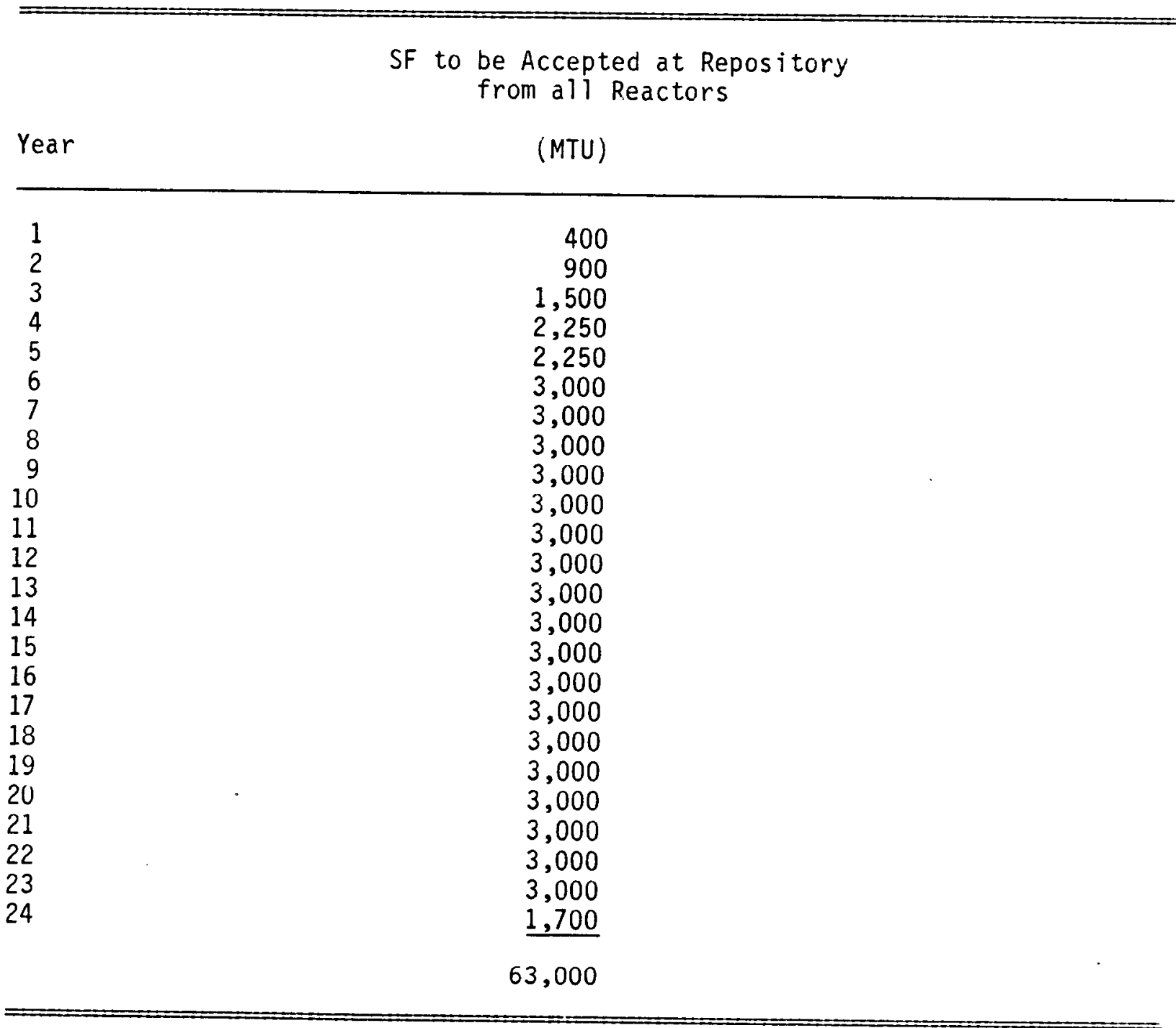

Source: Pacific Northwest Laboratory, 1988 (see MRS Action Plan [Ref. 1], Schedule 1, data files, August 26). 
Table 3. Spent Fuel Acceptance Schedule for No-Western-Strategy Cases (Networks 2 and 3)

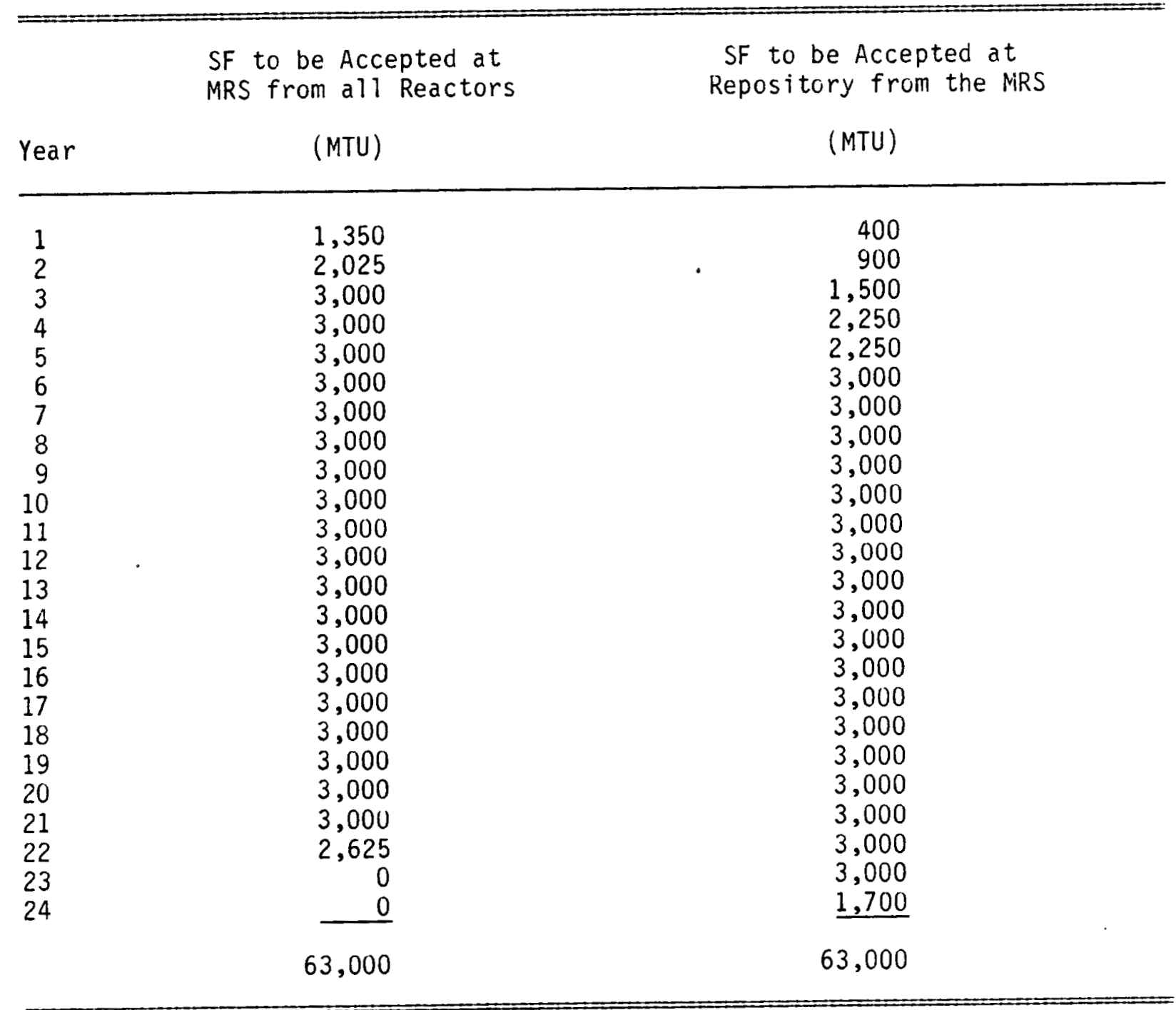

Source: Pacific Northwest Laboratory, 1988 (see MRS Action Plan [Ref. 1], Schedule 26 NOWEST, data files, September 1). 
Table 4. Spent Fuel Acceptance Schedule for Western-Strategy Cases (Network 4)

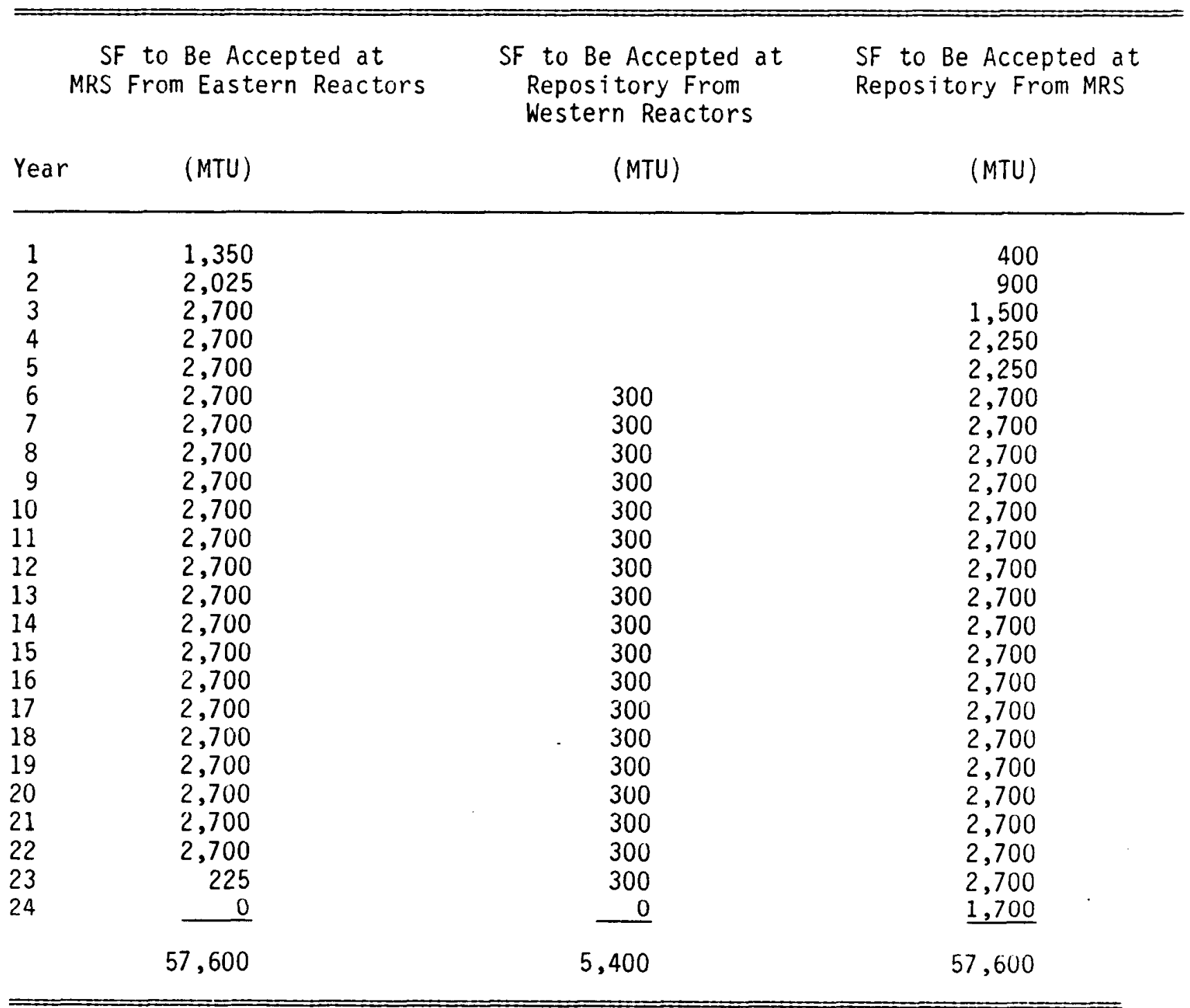

Source: Pacific Northwest Laboratory, 1988 (see MRS Action Plan [Ref. 1] Schedule 2 WEST, data files, September 2): 
Table 5. High-Level Waste Acceptance and Shipment Schedule

\begin{tabular}{|c|c|c|c|c|c|}
\hline \multirow{2}{*}{ Year } & \multirow{2}{*}{$\begin{array}{l}\text { Quantity of HLW to Be } \\
\text { Accepted at MRS or } \\
\text { Repository (MTU) }\end{array}$} & \multicolumn{4}{|c|}{ Shipment Schedule } \\
\hline & & $\begin{array}{c}\text { West } \\
\text { valley }\end{array}$ & $\begin{array}{l}\text { Savannah } \\
\text { River }\end{array}$ & $\begin{array}{l}\text { ICPP } \\
\text { (Idaho) }\end{array}$ & Hanford \\
\hline $\begin{array}{r}1 \\
2 \\
3 \\
4 \\
5 \\
6 \\
7 \\
8 \\
9 \\
10 \\
11 \\
12 \\
13 \\
14 \\
15 \\
16 \\
17 \\
18\end{array}$ & $\begin{array}{l}400 \\
400 \\
400 \\
400 \\
400 \\
400 \\
400 \\
400 \\
400 \\
400 \\
400 \\
400 \\
400 \\
400 \\
400 \\
400 \\
400 \\
200 \\
\end{array}$ & $\begin{array}{r}40 \\
400 \\
200 \\
\end{array}$ & $\begin{array}{r}400 \\
400 \\
368 \\
295 \\
306 \\
312 \\
266 \\
241 \\
231 \\
145 \\
57 \\
48 \\
37 \\
34 \\
34 \\
30\end{array}$ & $\begin{array}{l}106 \\
343 \\
352 \\
363 \\
366 \\
366 \\
330\end{array}$ & $\begin{array}{r}32 \\
105 \\
94 \\
88 \\
134 \\
159 \\
169 \\
149\end{array}$ \\
\hline & 7,000 & 640 & 3,204 & 2,226 & 930 \\
\hline
\end{tabular}

Source: Pacific Northwest Laboratory, 1988 (see MRS Action Plan (Ref. 1], High-Level Waste, September). 


\subsection{METHODOLOGY AND DATA}

The Transportation Risk and Cost Analysis Model (TRICAM) was used in this study to estimate transportation impacts. As previously noted, the investigation was limited to activities related directly to the transport of the waste. Specifically, loading and unloading activities were not considered because these are included in the facility impacts being examined under the other MRS System Study tasks. TRICAM is described in a paper (Ref. 3) that is included as Appendix C for the readers' convenience.

Briefly, the type of cask used to ship waste between each origin/ destination (O/D) pair is specified according to modal capability, waste form. and packaging. Using the route-specific data described in Section 3.2 and the mode of service involved, the cost and radiological dose are calculated for every 0/D pair. (Appendix A describes salient assumptions underlying the cost calculations.) These per-shipment costs and doses are multiplied by the quantities to be shipped to estimate annually cost and dose for every $0 / D$ pair. The transportation impacts for the duration of the shipping program are then calculated by summing up the annual impacts.

\subsection{COST AND DOSE DATA}

The categories of cost included in this analysis are:

- Capital cost of transportation casks

- Cask maintenance cost

- Hauling cost

- Inspection cost at the origin point

- In-transit security cost.

The categories of public dose included in this analysis are:

- Incident-free, off-link ${ }^{1}$

- Incident-free, on-link ${ }^{2}$

- Incident-free, at stops

- Accident-related, off-link

- Accident-related, on-link

- Accident-related, ingestion.

\subsection{ROUTE-SPECIFIC DATA}

Route-specific data for highway and rail transportation are generated using the routing models, HIGHWAY and INTERLINE respectively. These models have been described in the literature (Refs. 4, 5). Route data are provided on computer tapes in a format compatible with TRICAM.

1 off-link refers to population surrounding the highway or railroad track on which the shipment moves.

2 on-link refers to population sharing the highway or railroad track on which the shipment moves. 
The route data contain information for the entire route connecting every $0 / D$ pair in the transportation network, i.e., each reactor to the repository, each waste site to the MRS, and the MRS to the repository. The information for each $0 / D$ pair includes:

- The States through which the route passes

- Type of highways (not applicable to rail)

- Length of the route in miles

- Miles through each of 11 population density categories.

This level of detail is required for calculating route-specific costs and doses. Several hundred routes are typical in a TRICAM application.

\subsection{MODE OF SERVICE}

The type of transportation cask that would be used for shipments from individual waste generator sites depends on (1) cask-handling capability (which is primarily constrained by crane capacity) and (2) rail access to the loading bay. A reactor that has adequate crane capacity and rail access to the loading bay is assumed to be served by rail, using the 100-ton rail casks. Otherwise, the reactor is assumed to be served by truck, using the 28-ton truck casks. Table 6 shows the mode of service assumed in this study, for reactors in the EIA No-New-Orders scenario (Ref. 8). As indicated in the table, about $54 \%$ of the reactors are designated as rail-served and about $46 \%$ are truck-served, resulting in an MTU split of about 55\% rail and 45\% truck. Table 6 is based on current information about rail access and infrastructure at reactors. These conditions may change, leading to different modal assignments over time. All HLW sites are assumed to qualify for rail service using the above criteria. The MRS and repository are assumed to be designed to handle up to 150-ton rail casks.

\subsection{TRANSPORT CASK DATA}

Table 7 lists all of the cask systems used in this study. Shipments from reactors are made in either 100 -ton $21 / 48$ rail casks or 28 -ton $3 / 7$ truck casks, depending on modal access. Sensitivity analyses were performed as described in Chapter 5 for overweight 40-ton truck casks and various capacity from-reactor and from-MRS rail casks to show the effects of difference in cask capacity.

The four MRS packaging functions analyzed in this study produce three forms of waste: intact SF, consolidated SF, and non-fuel-bearing components (NFBC) resulting from disassembly of the fuel elements. One or more of the six SF casks listed in Table 7 for MRS-to-Repository shipments can be involved in shipping these waste forms, as clarified in Table 8.

HLW shipments use the 100-ton rail casks with five canisters per cask for shipments from the HLW sites and 150-ton rail casks with seven canisters per cask for shipments from the MRS to the repository.

Tables 9 and 10 give additional data on the transportation casks used in this study. 
Table 6. Mode of Service at Reactors in the EIA No-New-Orders Scenario (Page 1 of 3 )

\begin{tabular}{|c|c|c|}
\hline $\begin{array}{l}\text { Reactor } \\
\text { Name }\end{array}$ & State & $\begin{array}{l}\text { Mode of } \\
\text { Service }\end{array}$ \\
\hline ARK NUCLEAR 1 & AR & Rail \\
\hline ARK NUCLEAR 2 & AR & Rail \\
\hline BEAVER VALLEY 1 & PA & Rail \\
\hline BEAVER VALLEY 2 & PA & Rail \\
\hline BELLEFONTE 1 & $\mathrm{AL}$ & Rail \\
\hline BIG ROCK 1 & MI & Truck \\
\hline BRAIDWOOD & IL & Rail \\
\hline BRAIDWOOD 2 & IL & Rail \\
\hline BROWNS FERRY 1 & $A L$ & Truck \\
\hline BROWNS FERRY 2 & $A L$ & Truck \\
\hline BROWNS FERRY 3 & $A L$ & Truck \\
\hline BRUNSWICK 1 PWR POOL & NC & Truck \\
\hline BRUNSWICK 2 PWR POOL & $\mathrm{NC}$ & Truck \\
\hline BRUNSWICK 1 & NC & Truck \\
\hline BRUNSWICK & NC & Truck \\
\hline BYRON & IL & Rail \\
\hline BYRON & IL & Rail \\
\hline CALLAWAY 1 & MO & Truck \\
\hline CALVERT CLF 1 & MD & Truck \\
\hline CALVERT CLF 2 & MD & Truck \\
\hline CATAWBA 1 & SC & Rajl \\
\hline CATAWBA & SC & Rail \\
\hline CLINTON 1 & IL & Rail \\
\hline COMANCHE PK 1 & TX & Truck \\
\hline COMANCHE PK 2 & $T X$ & Truck \\
\hline COOK 1 & MI & Ra il \\
\hline COOK & MI & Rail \\
\hline COUPER STN & NE & Truck \\
\hline CRYSTAL RVR 3 & $F L$ & Truck \\
\hline DAVIS-BESSE 1 & $\mathrm{OH}$ & Rajl \\
\hline DIABLO CANYON 1 & $C A$ & Truck \\
\hline DIABLO CANYON 2 & $C A$ & Truck \\
\hline DRESDEN 1 & IL & Truck \\
\hline DRESDEN & IL & Rail \\
\hline DRESDEN 3 & IL & Rail \\
\hline DUANE ARNOLD & IA & Truck \\
\hline ENRICO FERMI 2 & MI & $\operatorname{Ra} i 1$ \\
\hline FARLEY 1 & $A L$ & Rail \\
\hline FARLEY 2 & $A L$ & Rail \\
\hline FITZPATRICK & NY & Rail \\
\hline FURT CALHOUN & NE & Truck \\
\hline GINNA & NY & Truck \\
\hline GRAND GULF 1 & MS & Truck \\
\hline HADDAM NECK & $\mathrm{CT}$ & Truck \\
\hline HARRIS 1 BWR POOL & NC & Truck \\
\hline
\end{tabular}


Table 6. Mode of Service at Reactors in the

EIA No-New-Orders Scenario (Page 2 of 3 )

\begin{tabular}{|c|c|c|c|}
\hline $\begin{array}{l}\text { Reactor } \\
\text { Name }\end{array}$ & & State & $\begin{array}{l}\text { Mode of } \\
\text { Service }\end{array}$ \\
\hline HARRIS & 1 & $N C$ & Truck \\
\hline HATCH & 1 & $\mathrm{GA}$ & Rail \\
\hline HATCH & 2 & GA & Rail \\
\hline HOPE CREEK & & NJ & Truck \\
\hline HUMBOLDT BAY & & $C A$ & Truck \\
\hline INDIAN PT & 1 & NY & Truck \\
\hline INDIAN PT & 2 & NY & Truck \\
\hline INDIAN PT & 3 & NY & Truck \\
\hline KEWAUNEE & & $W I$ & Truck \\
\hline LACROSSE & & WI & Truck \\
\hline LASALLE CTY & 1 & IL & Rail \\
\hline LASALLE CTY & 2 & IL & Rail \\
\hline LIMERICK & 1 & PA & Rail \\
\hline MAINE YANKEE & & $M E$ & Rail \\
\hline MCGUIRE & 1 & NC & Rail \\
\hline MCGUIRE & 2 & NC & Rail \\
\hline MILLSTONE & 1 & CT & Truck \\
\hline MILLSTONE & 2 & CT & Rail \\
\hline MILLSTUNE & 3 & $C T$ & Rail \\
\hline MONTICELLO & & MN & Truck \\
\hline MORRIS-BWR & & IL & Rail \\
\hline MURRIS-PWR & & IL & Rail \\
\hline NINE MILE PT & 1 & NY & Rail \\
\hline NINE MILE PT & 2 & NY & Rail \\
\hline NURTH ANNA & 1 & VA & Rail \\
\hline NURTH ANNA & 2 & VA & Rail \\
\hline OCONEE & 1 & SC & Truck \\
\hline OCONEE & 2 & SC & Truck \\
\hline OCONEE & 3 & SC & Truck \\
\hline UYSTER CRK & 1 & $\mathrm{NJ}$ & Truck \\
\hline PALISADES & & MI & Truck \\
\hline PALO VERDE & 1 & $A Z$ & Rail \\
\hline PALO VERDE & 2 & $A Z$ & Rail \\
\hline PALO VERDE & 3 & $A Z$ & Rail \\
\hline PEACHBOTTOM & 2 & PA & Truck \\
\hline PEACHBOTTOM & 3 & PA & Truck \\
\hline PERRY & 1 & $\mathrm{OH}$ & Rail \\
\hline PILGRIM & 1 & $M A$ & Truck \\
\hline POINT BEACH & 1 & WI & Truck \\
\hline PUINT BEACH & 2 & WI & Truck \\
\hline PRAIRIE ISL & 1 & $\mathrm{MN}$ & Rail \\
\hline PRAIRIE ISL & 2 & $M N$ & Rail \\
\hline QUAD CITIES & 1 & IL & Rail \\
\hline QUAD CITIES & 2 & IL & Rail \\
\hline RANCHO SECO & 1 & $C A$ & Truck \\
\hline
\end{tabular}


Table 6. Mode of Service at Reactors in the

EIA No-New-Orders Scenario (Page 3 of 3)

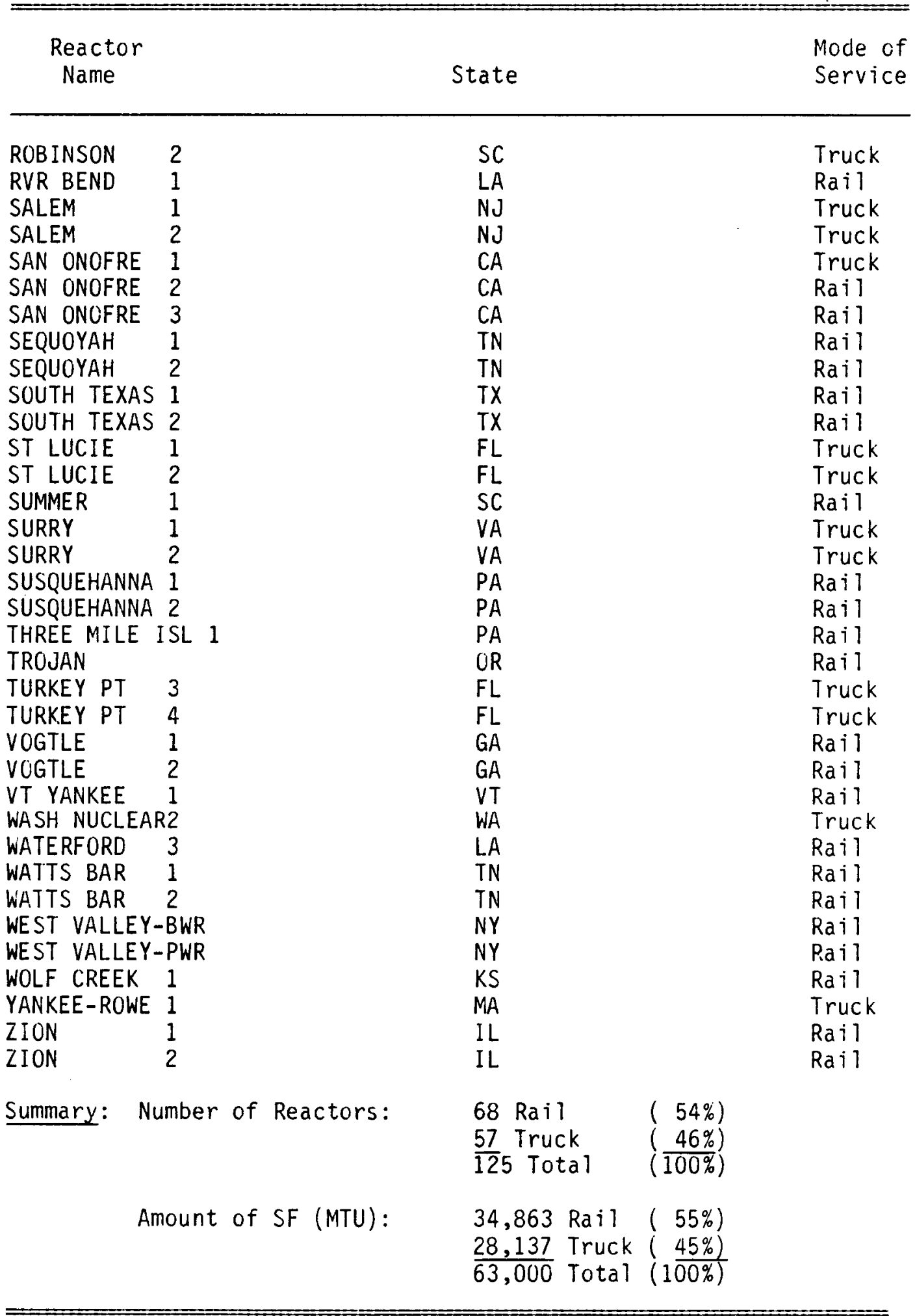


Table 7. Cask Systems Used in the Transportation Analysis

\begin{tabular}{|c|c|c|c|c|}
\hline $\begin{array}{l}\text { Cask } \\
\text { ID }\end{array}$ & Mode & $\begin{array}{l}\text { Loaded } \\
\text { Weight }\end{array}$ & $\begin{array}{l}\text { Waste } \\
\text { Form }\end{array}$ & Packaging \\
\hline
\end{tabular}

Waste Generators to MRS or Repository:

$\begin{array}{llrll}\text { R1 } & \text { Rail } & 100 \text { Tons } & \text { Intact SF } & \text { Bare Assemblies } \\ \text { T1 } & \text { Truck } & 28 \text { Tons } & \text { Intact SF } & \text { Bare Assemblies } \\ \text { T2 } & \text { Truck } & 40 \text { Tons } & \text { Intact SF } & \text { Bare Assemblies } \\ \text { TSC } & \text { Rail } & 125 \text { Tons } & \text { Intact SF } & \text { Bare Assemblies } \\ \text { R2 } & \text { Rail } & 100 \text { Tons } & \text { HLW } & \text { Canisters }\end{array}$

MRS to Repository:

$\begin{array}{lllll}\text { R3 } & \text { Rail } & 150 \text { Tons } & \text { Intact SF } & \text { Canisters/Bare Assemblies } \\ \text { R4 } & \text { Rail } & 150 \text { Tons } & \text { Consolidated SF } & \text { Canisters } \\ \text { R5 } & \text { Rail } & 133 \text { Tons } & \text { Intact SF } & \text { Containers } \\ \text { R6 } & \text { Rail } & 138 \text { Tons } & \text { Consolidated SF } & \text { Containers } \\ \text { R7 } & \text { Rail } & 125 \text { Tons } & \text { Intact SF } & \text { Containers } \\ \text { R8 } & \text { Rail } & 120 \text { Tons } & \text { NFBC } & \text { Canisters } \\ \text { R9 } & \text { Rail } & 150 \text { Tons } & \text { HLW } & \text { Containers }\end{array}$

\subsection{GENERIC MRS LOCATIONS}

The Task A Report (Ref. 2) requires that Eastern and Western MRS locations be used to examine how the location of the MRS facility might impact the transportation system for the various MRS configurations studied.

Identification of the generic MRS locations used in this analysis involved two steps. In the first step, six locations around the country were identified by dividing the geological coordinates (latitudes and longitudes) containing the continental United States into six regions of approximately equal dimensions and identifying the centroids of these regions. The coordinates of the regions and their centroids are shown in Table 11. This information is also presented in Figure 2. The second step is to average the two Eastern centroids (Fig. 2, centroids 5 and 6) to represent the generic Eastern MRS and the two Western centroids (Fig. 2, centroids 1 and 2) to represent the generic Western MRS, using the procedure below.

In TRICAM, every route (i.e., from every origin to every destination) is presented as a series of links. There is one link for every State, road type (Interstate, Primary U.S. Highway, and Secondary U.S. Highway), and population density zone (11 zones) traversed by that route. Mileage data are presented for each link. 
Table 8. Cask Systems Used for Shipments From MRS to Repository

\begin{tabular}{cccc} 
& & \multicolumn{2}{c}{ Cask Type } \\
& Waste Forms \\
Shipped & Packaging & Cask & Mode Weight \\
\hline
\end{tabular}

Store 0nly:

Intact SF

Bare Assemblies R3 Rail 150 Tons

\section{Consolidate \& Canister:}

Consolidated SF

Canisters

R4 Rail 150 Tons

Intact SF (5\% category)*

Canisters

R3

Rail 150 Tons

NFBC

Canisters

R8

Rail 120 Tons

Containerize Intact SF:

Intact SF

Containers

R5

Rail 133 Tons

Consolidate \& Containerize:

$\begin{array}{lllll}\text { Consolidated SF } & \text { Containers } & \text { R6 } & \text { Rail } & 138 \text { Tons } \\ \text { Intact SF (5\% category)* } & \text { Containers } & \text { R7 } & \text { Rail } & 125 \text { Tons } \\ \text { NFBC } & \text { (Transported in central voids of the } & \text { 138-ton cask) }\end{array}$

* An underlying assumption of the MRS System Study is that 5\% of SF will not be consolidated (Ref. 2, p. 11). 
Table 9. Data for Casks Used in Shipments

From Waste Generators to MRS/Repository

\begin{tabular}{lllll}
\hline & & & & \\
& & From-Reactor Cask Type & \\
Data Element & $\mathrm{R} 1$ & $\mathrm{T1}$ & $\mathrm{T2}$ & $\mathrm{R} 2$ \\
\hline
\end{tabular}

Physical Data:

Waste Form

Cask Capacity

Loaded Weight (1b)

Empty Weight (1b)
Intact SF

$21 / 48$

200,000

168,000
Intact SF

$3 / 7$

56,000

51,500
Intact $S F$

$5 / 12$

80,000

72,500
$H L W$

5 canisters

200,000

177,000

\section{Logistics Data:}

Mode

Cask Life (yr)

Availability (days/yr)

Cask Days at Origin

(cask days/shipment)

Cask Days at MRS/Repository

(cask days/shipment)

Cost Data (\$/cask):

Purchase Price

Annual Maintenance Cost
Rail

20

280

$18.0(2)$

$6.0(2)$

$\$ 2.0 \mathrm{M}$

$\$ 125 \mathrm{~K}$
Truck

20

310

Truck

20

310

Rail

20

310

2.0

2.0

1.5

1.5

$37.5(3)$

$37.5(3)$

(1) SF cask capacities are stated in PWR/BWR assemblies. For HLW, cask capacity is stated in canisters.

(2) Calculated for 3 casks per shipment, which is assumed to represent an average amount of fuel removed from a reactor in an annual re-fueling. See Appendix $A$ for additional information on the 3 casks per shipment assumption. At this point, dedicated trains have been used for analytical purposes to provide a conservative cost estimating assumption. The eventual operation of the transportation for the FWMS may or may not utilize dedicated trains as opposed to other forms of rail transport. It is assumed in this report that loaded casks are shipped in dedicated trains and empty casks arrive at reactors individually, by regular train.

(3) Round-trip dedicated trains of 5 casks per train are assumed for highlevel waste transport. The 5 cask shipping group reflects some reduction in shipping cost (as compared to smaller cask shipments) without severely impacting receiving facility capital cost or cask turraround time. See Appendix $A$ for additional information on the 5 cask per shipment assumption. 
Table 10. Data for Rail Casks Used in Shipments From MRS to Repository

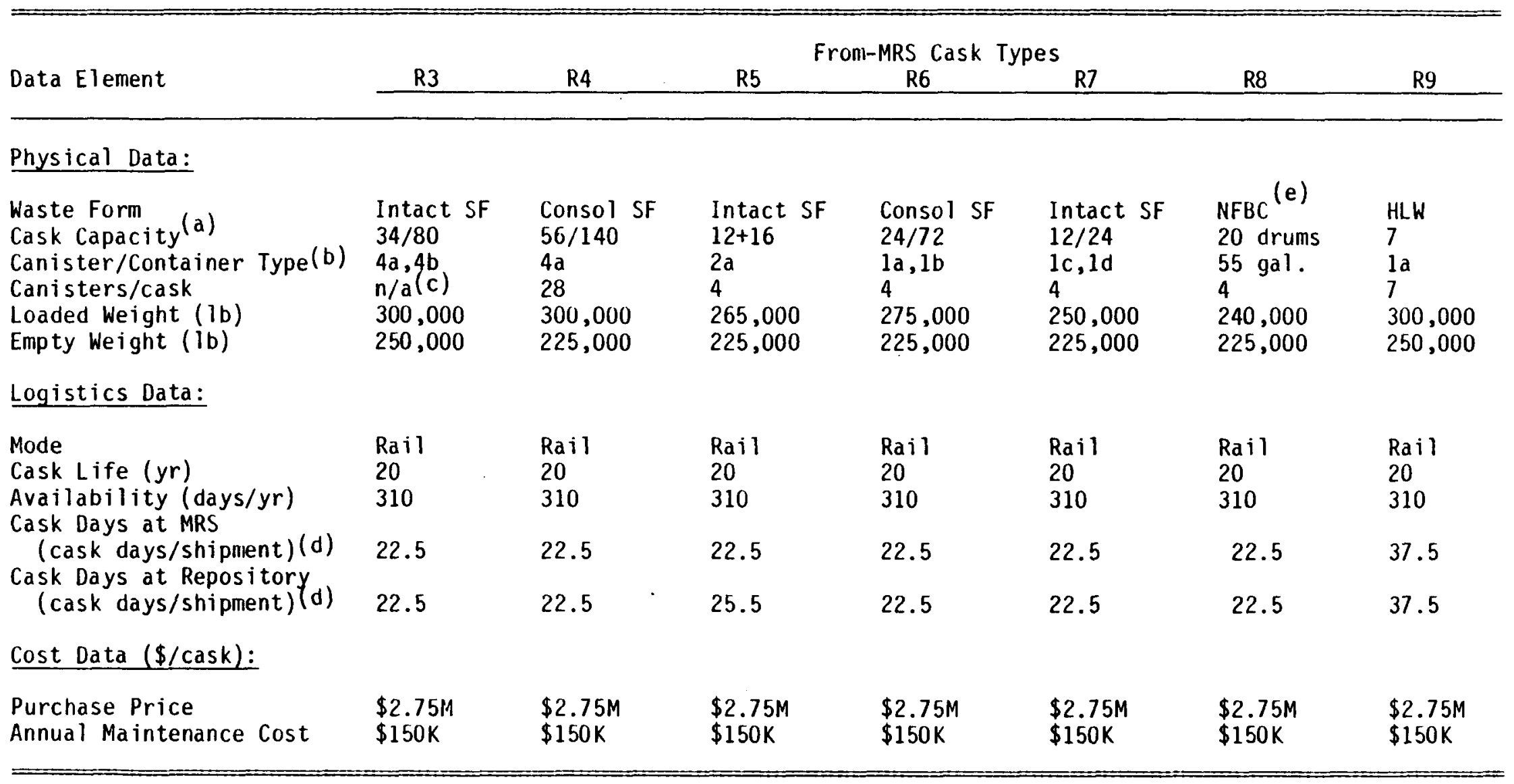

(a) MRS-repository rail cask capacity estimates developed/verified by Pacific Northwest Laboratory (see Ref. 2). SF cask capacities are stated in PWR/BWR assemblies. NFBC cask capacity is stated in 55-gallon drums. HLW cask capacity is stated in canisters.

(b) See Task A Report (Ref. 2) for descriptions of the canisters/containers.

(c) In the consolidate and canister cases, the 5\% category of SF that cannot be canistered will be shipped in single-assembly canisters. Source: Memo from Dick Smith, Pacific Northwest Laboratory, December $9,1988$.

(d) Calculated for 5 casks per shipment. It is assumed that shipments from the MRS and defense sites to the repository are made in (round-trip) dedicated trains. See Appendix B for additional information on the mul tiple-cask shipment assumption.

(e) It is assumed that 2 NFBC casks are transported in the same dedicated train with 5 consolidated spent fuel $56 / 140$ casks. 
Table 11. Six Regions ard Their Centroids

\begin{tabular}{|c|c|c|c|c|}
\hline \multirow{2}{*}{$\begin{array}{l}\text { Region } \\
\text { Number }\end{array}$} & \multicolumn{2}{|c|}{ Bounding } & \multicolumn{2}{|c|}{ Centroids } \\
\hline & $\begin{array}{r}\text { Latitudes } \\
\text { (de }\end{array}$ & $\begin{array}{l}\text { Longitudes } \\
\text { ees) }\end{array}$ & $\begin{array}{r}\text { Latitude } \\
\text { (des }\end{array}$ & $\begin{array}{l}\text { Longitude } \\
\text { es) }\end{array}$ \\
\hline $\begin{array}{l}1 \\
2 \\
3 \\
4 \\
5 \\
6\end{array}$ & $\begin{array}{l}39 \text { and } 48 \\
30 \text { and } 39 \\
39 \text { and } 48 \\
30 \text { and } 39 \\
39 \text { and } 48 \\
30 \text { and } 39\end{array}$ & $\begin{array}{r}106 \text { and } 124 \\
106 \text { and } 124 \\
88 \text { and } 106 \\
88 \text { and } 106 \\
68 \text { and } 88 \\
68 \text { and } 88\end{array}$ & $\begin{array}{l}43.5 \\
34.5 \\
43.5 \\
34.5 \star \\
43.0^{\star} \\
35.0^{*}\end{array}$ & $\begin{array}{r}115.0 \\
115.0 \\
97.0 \\
97.0 \\
78.0 \\
78.0\end{array}$ \\
\hline
\end{tabular}

(*) These latitudes were adjusted slightly to ensure that the locations fall within U.S. land area.

Thus, each link represents a highway type, with the population density within the given State traversed. In calculating route data for the generic Eastern or Western MRS, route data from the two corresponding centroids are averaged--i.e., route data for the two Eastern centroids, 5 and 6, are averaged for a generic Eastern MRS, and route data for the two western centroids, 1 and 2, are averaged for the generic Western MRS. Thus, a composite set of route data is created representing an average of miles, with population densities, and, where applicable, highway types between the respective centroids. Accordingly, the generic Eastern MRS and the generic Western MRS do not necessarily represent any one location. Detailed examples of the averaging method used in defining the two generic MRS locations are provided in Appendix $B$.

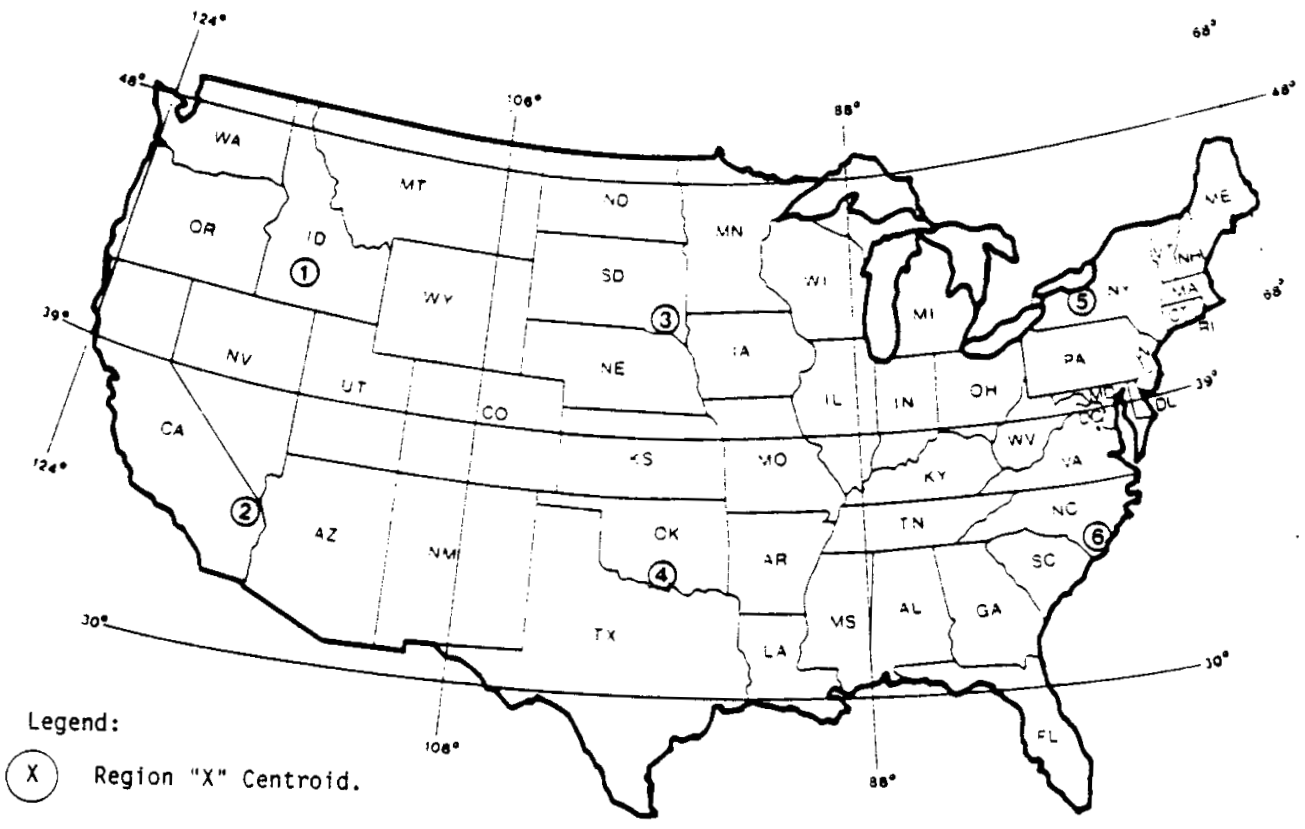

Figure 2. The Six MRS Regional Centroids 


\subsection{RESULTS}

\subsection{SPENT FUEL CASES}

The results of the eleven spent fuel (SF) cases are presented in this chapter. Additional results from sensitivity analysis of SF transportation are given in Chapter 5. The summary results--cost, dose, number of shipments, shipment-miles, cask-miles, and MTU-miles--are supported by a series of detailed tables, Tables 12 through 20, organized by transportation link (reactors to MRS, by mode and MRS to repository), to aid in interpreting the results. Information on cask days in transit, shipment days in transit, and average number of in-transit shipments per day for each case is given in Table 14. The summary information presented in Tables 12 and 14 is disaggregated by mode and transportation link in Tables 15 through 20.

Table 12 shows the summary transportation cost and dose results for the eleven SF cases, organized by MRS packaging function, MRS location, and Western fuel strategy. The transportation cost for the No-MRS case--the base case for comparison purposes--is $\$ 832$ million. MRS packaging function is an important determinant of transportation cost. Regardless of MRS location, the least-cost option is where the MRS consolidates and canisters the SF ( $\$ 634-862$ million), followed by a store-only MRS (\$741-896 million). The least attractive MRS option from the transportation cost perspective is an MRS that containerizes intact SF $(\$ 996-1,120$ million). This results because in the latter case (containerization of intact fuel), cask capacity is reduced, thus requiring more shipments.

The transportation costs for an MRS that consolidates and containerizes SF fall between $\$ 942$ and $\$ 965$ million, depending on location. The consolidateand-canister case allows for very efficient loading of spent fuel (approximately 26 MTU per cask). The two casks carrying non-fuel-bearing components (NFBC) travel in the same dedicated train with the five SF casks. A shipping charge is added for the two NFBC casks, but they do not incur a separate dedicated rail charge. As a result, the consolidation at MRS increases the MTU carried in each shipment without significantly affecting the per shipment cost. The cask carrying intact elements without containers (store-only MRS), is the next most efficient, with a capacity of about 15 MTU per cask.

The cases that involve carrying repository containers incur a transportation cost penalty due to the inefficiency of the repository container when used in transportation casks. The repository container is a cylinder with a larger diameter than the square boxes of fuel pins transported in the consolidate-andcanister case or the intact fuel elements carried in the store-only case. The large cylindrical repository containers do not pack efficiently into the shipping casks, resulting in reduced cask capacity. A cask carrying intact fuel in repository containers has a double penalty in that the intact fuel does not efficiently use the space inside the container. Also, the containers do not efficiently fit into the shipping cask. This results in lower capacity for the

${ }^{1}$ It should be noted that the cost and doses generated for the store only MRS assume all fuel destined for the first repository $(63,000$ MTU) would be processed by the MRS. If a lesser amount were shipped to a store only MRS, cost and dose results would change. 
Table 12. Summary of Life-Cycle Transportation Costs and Doses for 24-Year Shipping Campaign (Spent Fuel Cases)

\begin{tabular}{|c|c|c|}
\hline Cases & $\begin{array}{l}\text { Totalcost } \\
\text { (\$million) }\end{array}$ & $\begin{array}{c}\text { Total Dose } \\
(1000 \text { person }- \text { rem })\end{array}$ \\
\hline No-MRS: & 832 & 2.6 \\
\hline \multicolumn{3}{|l|}{ Store Only: } \\
\hline $\begin{array}{l}\text { Eastern MRS } \\
\text { Eastern MRS/ }\end{array}$ & 835 & 1.6 \\
\hline $\begin{array}{l}\text { Western Strategy } \\
\text { Western MRS }\end{array}$ & $\begin{array}{l}741 \\
896\end{array}$ & $\begin{array}{l}1.5 \\
2.5\end{array}$ \\
\hline \multicolumn{3}{|l|}{ Consolidate \& Canister: } \\
\hline $\begin{array}{l}\text { Eastern MRS } \\
\text { Eastern MRS/ }\end{array}$ & 718 & 1.5 \\
\hline $\begin{array}{l}\text { Western Strategy } \\
\text { Western MRS }\end{array}$ & $\begin{array}{l}634 \\
862\end{array}$ & $\begin{array}{l}1.4 \\
2.5\end{array}$ \\
\hline \multicolumn{3}{|l|}{ Containerize Intact SF: } \\
\hline $\begin{array}{l}\text { Eastern MRS } \\
\text { Western MRS }\end{array}$ & $\begin{array}{r}1,120 \\
996\end{array}$ & $\begin{array}{l}1.9 \\
2.6\end{array}$ \\
\hline \multicolumn{3}{|c|}{ Consolidate \& Containerize: } \\
\hline $\begin{array}{l}\text { Eastern MRS } \\
\text { Western MRS }\end{array}$ & $\begin{array}{l}965 \\
942\end{array}$ & $\begin{array}{l}1.8 \\
2.5\end{array}$ \\
\hline
\end{tabular}

Table 13. Summary of Life-Cycle Transportation Cost and Dose by MRS Location for 24-Year Shipping Campaign (Spent Fuel Cases)

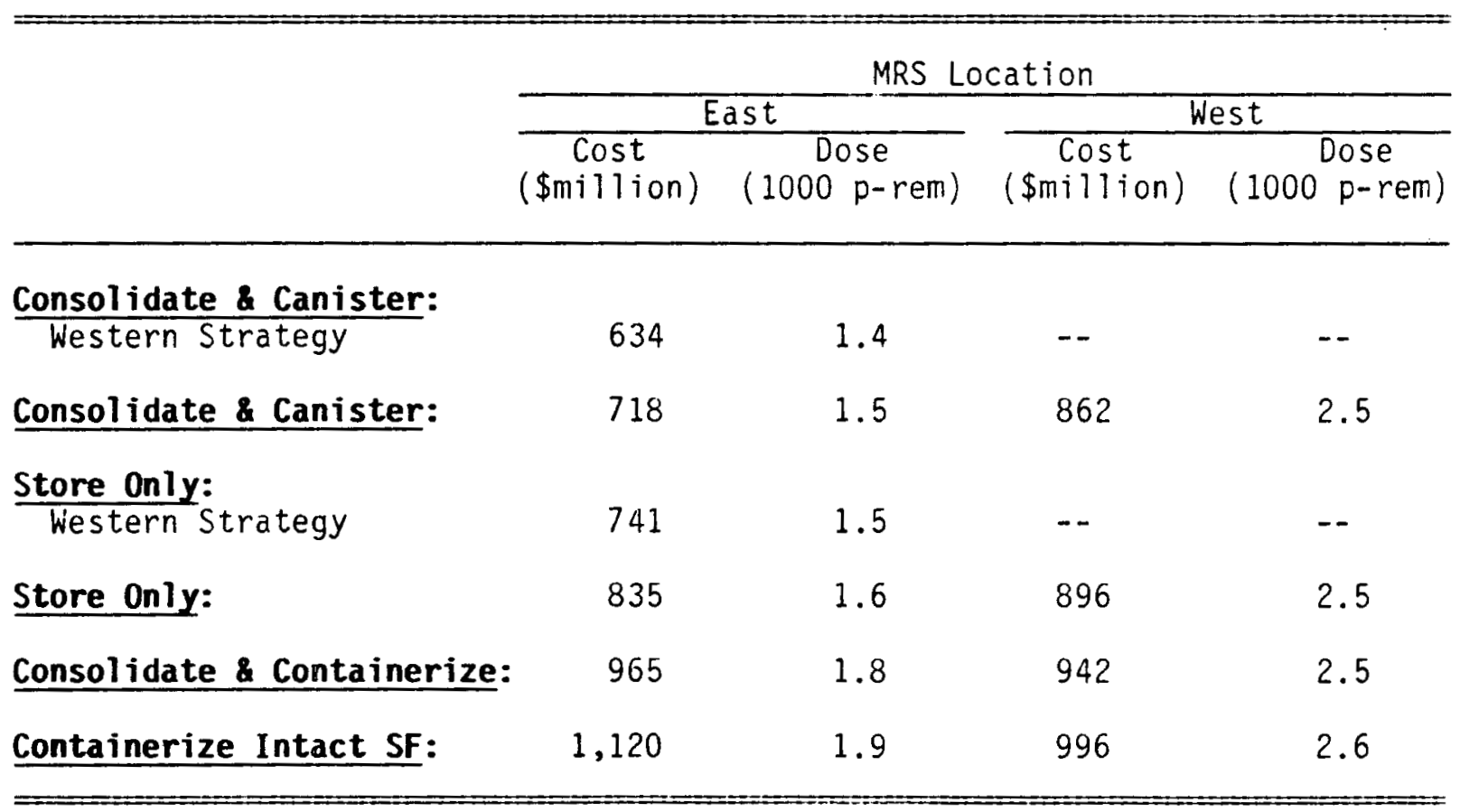


Table 14. Measures of Life-Cycle Transportation Impacts for 24-Year Shipping Campaign (Spent Fuel Cases)

\begin{tabular}{|c|c|c|c|c|c|c|c|}
\hline Cases & $\begin{array}{l}\text { Total } \\
\text { Number of } \\
\text { Shipments }\end{array}$ & $\begin{array}{l}\text { Total } \\
\text { Shipment } \\
\text { Miles } \\
(1,000 \mathrm{~s})\end{array}$ & $\begin{array}{l}\text { Total } \\
\text { Cask } \\
\text { Miles } \\
(1,000 \mathrm{~s})\end{array}$ & $\begin{array}{l}\text { Total } \\
\text { MTU } \\
\text { Miles } \\
(1,000 \mathrm{~s})\end{array}$ & $\begin{array}{l}\text { Total } \\
\text { Cask Days } \\
\text { In Transit }\end{array}$ & $\begin{array}{c}\text { Total } \\
\text { Shipment } \\
\text { Days } \\
\text { In Transit }\end{array}$ & $\begin{array}{r}\text { Total } \\
\text { Average } \\
\text { Shipments } \\
\text { Per Day }\end{array}$ \\
\hline No-MRS: & 23,836 & 54,235 & 60,685 & 148,685 & 65,627 & 58,762 & 6.7 \\
\hline \multicolumn{8}{|l|}{ Store 0nly: } \\
\hline $\begin{array}{l}\text { Eastern MRS } \\
\text { Eastern MRS/ }\end{array}$ & 24,649 & 25,951 & 37,777 & 242,403 & 42,033 & 28,794 & 3.6 \\
\hline $\begin{array}{l}\text { Western Strategy } \\
\text { Western MRS }\end{array}$ & $\begin{array}{l}24,635 \\
24,649\end{array}$ & $\begin{array}{l}20,151 \\
49,847\end{array}$ & $\begin{array}{l}30,893 \\
57,464\end{array}$ & $\begin{array}{l}216,617 \\
173,591\end{array}$ & $\begin{array}{l}34,913 \\
65,139\end{array}$ & $\begin{array}{l}22,686 \\
54,522\end{array}$ & $\begin{array}{l}2.8 \\
6.8\end{array}$ \\
\hline \multicolumn{8}{|l|}{ Consolidate Canister: } \\
\hline $\begin{array}{l}\text { Eastern MRS } \\
\text { Eastern MRS/ }\end{array}$ & 24,336 & 25,041 & 33,257 & 242,403 & 37,539 & 27,895 & 3.5 \\
\hline $\begin{array}{l}\text { Western Strategy* } \\
\text { Western MRS* }\end{array}$ & $\begin{array}{l}24,348 \\
24,336\end{array}$ & $\begin{array}{l}19,321 \\
49,647\end{array}$ & $\begin{array}{l}26,673 \\
56,484\end{array}$ & $\begin{array}{l}216,617 \\
173,591\end{array}$ & $\begin{array}{l}30,804 \\
63,139\end{array}$ & $\begin{array}{l}21,865 \\
54,122\end{array}$ & $\begin{array}{l}2.7 \\
6.7\end{array}$ \\
\hline \multicolumn{8}{|l|}{ Containerize Intact SF: } \\
\hline $\begin{array}{l}\text { Eastern MRS } \\
\text { Western MRS }\end{array}$ & $\begin{array}{l}25,308 \\
25,308\end{array}$ & $\begin{array}{l}27,851 \\
50,257\end{array}$ & $\begin{array}{l}47,277 \\
59,534\end{array}$ & $\begin{array}{l}242,403 \\
173,591\end{array}$ & $\begin{array}{l}51,482 \\
69,342\end{array}$ & $\begin{array}{l}30,683 \\
55,362\end{array}$ & $\begin{array}{l}3.8 \\
6.9\end{array}$ \\
\hline \multicolumn{8}{|c|}{ Consolidate \& Containerize: } \\
\hline $\begin{array}{l}\text { Eastern MRS } \\
\text { Western MRS }\end{array}$ & $\begin{array}{l}24,959 \\
24,959\end{array}$ & $\begin{array}{l}26,841 \\
50,042\end{array}$ & $\begin{array}{l}42,237 \\
58,439\end{array}$ & $\begin{array}{l}242,403 \\
173,591\end{array}$ & $\begin{array}{l}46,467 \\
67,111\end{array}$ & $\begin{array}{l}29,680 \\
54,916\end{array}$ & $\begin{array}{l}3.7 \\
6.8\end{array}$ \\
\hline
\end{tabular}

* Includes only spent fuel casks. The two NFBC casks per spent fuel shipment from the MRS are not included. 
Table 15. Life-Cycle Cost by Transportation Link (\$millions) for 24-Year Shipping Campaign (Spent Fuel Cases)

\begin{tabular}{|c|c|c|c|}
\hline \multirow[b]{2}{*}{ Case } & \multicolumn{2}{|c|}{$\begin{array}{l}\text { From Reactor tc } \\
\text { MRS/Repository }\end{array}$} & \multirow{2}{*}{$\frac{\text { From MRS to Repository }}{\text { Rail }}$} \\
\hline & $\overline{R a i l}$ & Truck & \\
\hline NO-MRS: & 260 & 572 & -- \\
\hline \multicolumn{4}{|l|}{ Store Only: } \\
\hline $\begin{array}{l}\text { Eastern MRS } \\
\text { Eastern MRS/ }\end{array}$ & 135 & 326 & 374 \\
\hline $\begin{array}{l}\text { Western Strategy } \\
\text { Western MRS }\end{array}$ & $\begin{array}{l}126 \\
241\end{array}$ & $\begin{array}{l}273 \\
524\end{array}$ & $\begin{array}{l}342 \\
131\end{array}$ \\
\hline \multicolumn{4}{|c|}{ Consolidate \& Canister: } \\
\hline $\begin{array}{l}\text { Eastern MRS } \\
\text { Eastern MRS/ }\end{array}$ & 135 & 326 & 257 \\
\hline $\begin{array}{l}\text { Western Strategy } \\
\text { western MRS }\end{array}$ & $\begin{array}{l}126 \\
241\end{array}$ & $\begin{array}{l}273 \\
524\end{array}$ & $\begin{array}{r}235 \\
97\end{array}$ \\
\hline \multicolumn{4}{|l|}{ Containerize Intact SF: } \\
\hline $\begin{array}{l}\text { Eastern MRS } \\
\text { Western MRS }\end{array}$ & $\begin{array}{l}135 \\
241\end{array}$ & $\begin{array}{l}326 \\
524\end{array}$ & $\begin{array}{l}659 \\
231\end{array}$ \\
\hline \multicolumn{4}{|c|}{ Consolidate \& Containerize: } \\
\hline $\begin{array}{l}\text { Eastern MRS } \\
\text { Western MRS }\end{array}$ & $\begin{array}{l}135 \\
241\end{array}$ & $\begin{array}{l}326 \\
524\end{array}$ & $\begin{array}{l}504 \\
177\end{array}$ \\
\hline
\end{tabular}

cask in the containerize intact case (8.6 MTU per cask) than in other cases, and thus higher costs. The consolidate-and-containerize case increases the container capacity by loading it with consolidated fuel pins and compacted NFBC, so the cask capacity increases (12 MTU per cask) in comparison to the containerize-intact case. However, capacity is still lower and costs higher than for the store-only or consolidate-and-canister cases.

With the store-only and consolidate/canister packaging cases, the generic Eastern MRS is less expensive than the generic Western MRS because of the reduced shipment-miles. The Western strategy further reduces the shipmentmiles and enhances the Eastern MRS advantage. However, in the other two cases that involve containerization, the western MRS is less costly because the total shipment-mile reduction is not adequate to compensate for the three-fold increase of the cross-country shipments from the Eastern MRS to the repository when compared to the noncontainerizing packaging options. This increase in the number of shipments is a result of inefficient packaging of the disposal containers in the transportation casks.

For total transportation dose, MRS location is the dominant factor because location affects shipping distance and the distance traveled (i.e., cask-miles) directly impacts the total number of individuals exposed. Dose estimates for the cases where the MRS is located in the East fall within a narrow band of 1.4 to 1.9 thousand person-rem over the operational life of the system. The no-MRS 
Table 16. Dose by Transportation Link (1,000s person-rem) for 24-Year Shipping Campaign (Spent Fuel Cases)

\begin{tabular}{|c|c|c|c|}
\hline \multirow[b]{2}{*}{ Case } & \multicolumn{2}{|c|}{$\begin{array}{l}\text { From Reactor to } \\
\text { MRS/Repository }\end{array}$} & \multirow{2}{*}{$\frac{\text { From MRS to Repository }}{\text { Rail }}$} \\
\hline & Rail & Truck & \\
\hline No-MRS: & 0.7 & 1.9 & -- \\
\hline \multicolumn{4}{|l|}{ Store Only: } \\
\hline $\begin{array}{l}\text { Eastern MRS } \\
\text { Eastern MRS/ }\end{array}$ & 0.4 & 0.9 & 0.3 \\
\hline $\begin{array}{l}\text { Western Strategy } \\
\text { Western MRS }\end{array}$ & $\begin{array}{l}0.4 \\
0.7\end{array}$ & $\begin{array}{l}0.8 \\
1.7\end{array}$ & $\begin{array}{l}0.3 \\
0.1\end{array}$ \\
\hline \multicolumn{4}{|c|}{ Consolidate \& Canister: } \\
\hline $\begin{array}{l}\text { Eastern MRS } \\
\text { Eastern MRS/ }\end{array}$ & 0.4 & 0.9 & 0.2 \\
\hline Western Strategy & 0.4 & 0.8 & 0.2 \\
\hline Western MRS & 0.7 & 1.7 & 0.1 \\
\hline \multicolumn{4}{|l|}{ Containerize Intact SF: } \\
\hline Eastern MRS & 0.4 & 0.9 & 0.6 \\
\hline Western MRS & 0.7 & 1.7 & 0.2 \\
\hline \multicolumn{4}{|c|}{ Consolidate \& Containerize: } \\
\hline $\begin{array}{l}\text { Eastern MRS } \\
\text { Western MRS }\end{array}$ & $\begin{array}{l}0.4 \\
0.7\end{array}$ & $\begin{array}{l}0.9 \\
1.7\end{array}$ & $\begin{array}{l}0.5 \\
0.1\end{array}$ \\
\hline
\end{tabular}

and Western MRS options also fall within a narrow, but higher, band (2.5 to 2.6 thousand person-rem). The dose is related to cask-miles traveled. The higher dose for the no-MRS and Western MRS options is explained by the increased caskmiles traveled. These two cases require about 60 million cask-miles each, whereas the various Eastern MRS cases require about $35 \mathrm{million}$ cask-miles each. All casks are assumed to operate at the regulatory 1 imit (10 mrem per hour at 2 meters) regardless of design or payload, and the dose per cask mile is independent of the cask type.

Table 13 addresses the question of whether packaging function has an effect on the transportation cost with respect to the Eastern or Western MRS location. If the MRS is to be located in the East, then the choice of packaging function can noticeably impact transportation costs ranging from an MRS that consolidates and canisters ( $\$ 634 \mathrm{million}$ ) to one that containerizes intact spent fuel ( $\$ 1,120 \mathrm{million})$. Thus, when packaging functions increase MRS cask capacity, the number of shipment-miles is reduced particularly in the East where MRS casks are shipped across the country. Alternatively, if an MRS is to be located in the West, then the choice of packaging function is by comparison less significant in terms of transportation cost (\$862-996 million). Note that, in general, the use of the Western strategy with an Eastern MRS results in additional cost savings of less than $\$ 100$ million. The Western strategy reduces cost by eliminating transportation of spent fuel from western reactors 
Table 17. Number of Shipments by Transportation Link for 24-Year Shipping Campaign (Spent Fuel Cases)

\begin{tabular}{|c|c|c|c|c|c|}
\hline & \multicolumn{2}{|c|}{$\begin{array}{c}\text { From Reactor } \\
\text { to MRS } \\
\end{array}$} & \multicolumn{2}{|c|}{$\begin{array}{l}\text { From Reactor } \\
\text { to Repository } \\
\end{array}$} & \multirow{2}{*}{$\begin{array}{l}\text { From MRS } \\
\text { Repository } \\
\text { Rail }\end{array}$} \\
\hline & RaiT & Truck & Rail & Truck & \\
\hline No-MRS: & -- & -- & 1,286 & 22,550 & -- \\
\hline \multicolumn{6}{|l|}{ Store Only: } \\
\hline $\begin{array}{l}\text { Eastern MRS } \\
\text { Eastern MRS/ }\end{array}$ & 1,286 & 22,550 & -- & -- & 813 \\
\hline Western Strategy & 1,204 & 19,894 & 80 & 2,713 & 744 \\
\hline Western MRS & 1,286 & 22,550 & -- & -- & 813 \\
\hline \multicolumn{6}{|c|}{ Consolidate \& Canister: } \\
\hline $\begin{array}{l}\text { Eastern MRS } \\
\text { Eastern MRS/ }\end{array}$ & 1,286 & 22,550 & -- & -- & 500 \\
\hline $\begin{array}{l}\text { Western Strategy } \\
\text { Western MRS }\end{array}$ & $\begin{array}{l}1,204 \\
1,286\end{array}$ & $\begin{array}{l}19,894 \\
22,550\end{array}$ & $\begin{array}{l}80 \\
--\end{array}$ & $\begin{array}{c}2,713 \\
-.\end{array}$ & $\begin{array}{l}457 \\
500\end{array}$ \\
\hline \multicolumn{6}{|c|}{ Containerize Intact SF: } \\
\hline $\begin{array}{l}\text { Eastern MRS } \\
\text { Western MRS }\end{array}$ & $\begin{array}{l}1,286 \\
1,286\end{array}$ & $\begin{array}{l}22,550 \\
22,550\end{array}$ & -- & -- & $\begin{array}{l}1,472 \\
1,472\end{array}$ \\
\hline \multicolumn{6}{|c|}{ Consolidate \& Containerize: } \\
\hline $\begin{array}{l}\text { Eastern MRS } \\
\text { Western MRS }\end{array}$ & $\begin{array}{l}1,286 \\
1,286\end{array}$ & $\begin{array}{l}22,550 \\
22,550\end{array}$ & $\begin{array}{l}-- \\
--\end{array}$ & $\begin{array}{ll}- \\
\cdots\end{array}$ & $\begin{array}{l}1,123 \\
1,123\end{array}$ \\
\hline
\end{tabular}

across the country to the MRS located in the East and then return-shipping the spent fuel back across the country from the MRS to the repository.

Table 14 shows the effects of transportation packaging function and MRS location with respect to the following seven categories: number of shipments, shipment-miles, cask-miles, MTU-miles, cask days in transit, shipment days in transit, and the average number of shipments in transit per day. The number of shipments is the total MTU transported divided by cask capacity and the number of casks per shipment. A fixed quantity of fuel $(63,000 \mathrm{MTU})$ is transported in al1 11 cases, and thus, variations in the total number of shipments are due to the choice of an MRS packaging function. As shown in Table 17, the number of from-reactor shipments is approximately the same for all MRS cases (rail 1,286 and truck 22,550$)$, and the number of from-MRS shipments ranges from 457 to 1,472 . For the MRS-system options, the total number of shipments varies from 24.3 to 25.3 thousand, and for the no-MRS option, total shipments is about 24 thousand.

Total number of shipment-miles reported in Table 14 is the number of shipments from each facility multiplied by the one-way distance from that facility to an MRS/repository. Variations in total shipment-miles are due to MRS packaging function, MRS location, and the use of a Western strategy. The 
Table 18. Shipment-Miles by Transportation Link (1,000s)

for 24-Year Shipping Campaign (Spent Fuel Cases)

\begin{tabular}{|c|c|c|c|c|c|}
\hline & $\begin{array}{r}\text { From } \\
\text { to }\end{array}$ & $\begin{array}{l}\text { Reactor } \\
\text { MRS }\end{array}$ & $\begin{array}{l}\text { From } \\
\text { to Re }\end{array}$ & $\begin{array}{l}\text { ctor } \\
\text { itory }\end{array}$ & $\begin{array}{l}\text { From MRS to } \\
\text { Repository }\end{array}$ \\
\hline & RaiT & Truck & $\operatorname{Rai1}$ & Truck & Rail \\
\hline No-MRS: & -- & -- & 3,095 & 51,140 & -- \\
\hline Store Only: & & & & & \\
\hline $\begin{array}{l}\text { Eastern MRS } \\
\text { Eastern MRS/ }\end{array}$ & 1,218 & 22,383 & -- & -- & 2,350 \\
\hline $\begin{array}{l}\text { Western Strategy } \\
\text { Western MRS }\end{array}$ & $\begin{array}{l}1,011 \\
2,788\end{array}$ & $\begin{array}{l}15,234 \\
46,549\end{array}$ & $\begin{array}{l}70 \\
--\end{array}$ & 1,686 & $\begin{array}{r}2,150 \\
510\end{array}$ \\
\hline Consolidate \& Caniste & & & & & \\
\hline $\begin{array}{l}\text { Eastern MRS } \\
\text { Eastern MRS/ }\end{array}$ & 1,218 & 22,383 & -- & -- & 1,440 \\
\hline $\begin{array}{l}\text { Western Strategy } \\
\text { Western MRS }\end{array}$ & $\begin{array}{l}1,011 \\
2,788\end{array}$ & $\begin{array}{l}15,234 \\
46,549\end{array}$ & $\begin{array}{l}70 \\
--\end{array}$ & $\begin{array}{c}1,686 \\
\ldots\end{array}$ & $\begin{array}{r}1,320 \\
310\end{array}$ \\
\hline Containerize Intact S & & & & & \\
\hline $\begin{array}{l}\text { Eastern MRS } \\
\text { Western MRS }\end{array}$ & $\begin{array}{l}1,218 \\
2,788\end{array}$ & $\begin{array}{l}22,383 \\
46,549\end{array}$ & -- & $\begin{array}{ll}-- \\
-\end{array}$ & $\begin{array}{r}4,250 \\
920\end{array}$ \\
\hline Consolidate \& Contain & & & & & \\
\hline $\begin{array}{l}\text { Eastern MRS } \\
\text { western MRS }\end{array}$ & $\begin{array}{l}1,218 \\
2,788\end{array}$ & $\begin{array}{l}22,383 \\
46,549\end{array}$ & -- & -- & $\begin{array}{r}3,240 \\
705\end{array}$ \\
\hline
\end{tabular}

no-MRS and the Western-MRS options result in relatively similar shipment-miles (54 million and about 52 million, respectively).

For the MRS cases, location is the most dominant factor in determining total shipment-miles. As seen in Table 18, from-reactor shipment-miles are the same for all Eastern MRS/no Western strategy cases (about 1 million for rail and 22 million for truck), for Eastern MRS/Western strategy cases (about 1 million for rail and $15 \mathrm{million}$ for truck), and for Western MRS cases (about 3 million for rail and 46 million for truck). This is expected because the packaging function remains the same for all reactor-to-MRS shipments under any MRS packaging scenario. Estimates of shipment-miles for from-MRS transport constitute only about $1 \%$ to $7 \%$ of the total shipment-miles for all 11 SF cases reported in Table 14. From-reactor shipment-miles are a function of MRS location and application or nonapplication of a Western strategy. The MRS packaging function does not affect shipments from reactors to the MRS. The transfer of fuel from rail or truck casks to the larger capacity MRS casks greatly reduces the number of shipments from the MRS, thus reducing the contribution of MRS shipments to total shipment-miles.

Total cask-miles is the number of cask loads shipped from each facility multiplied by the one-way distance from that facility to an MRS/repository. Similar to shipment-miles, total cask-miles varies with MRS location. Total cask-miles for the no-MRS and Western-MRS cases are relatively equivalent 
Table 19. Cask-Miles by Transportation Link (1,000s) for 24-Year Shipping Campaign (Spent Fuel Cases)

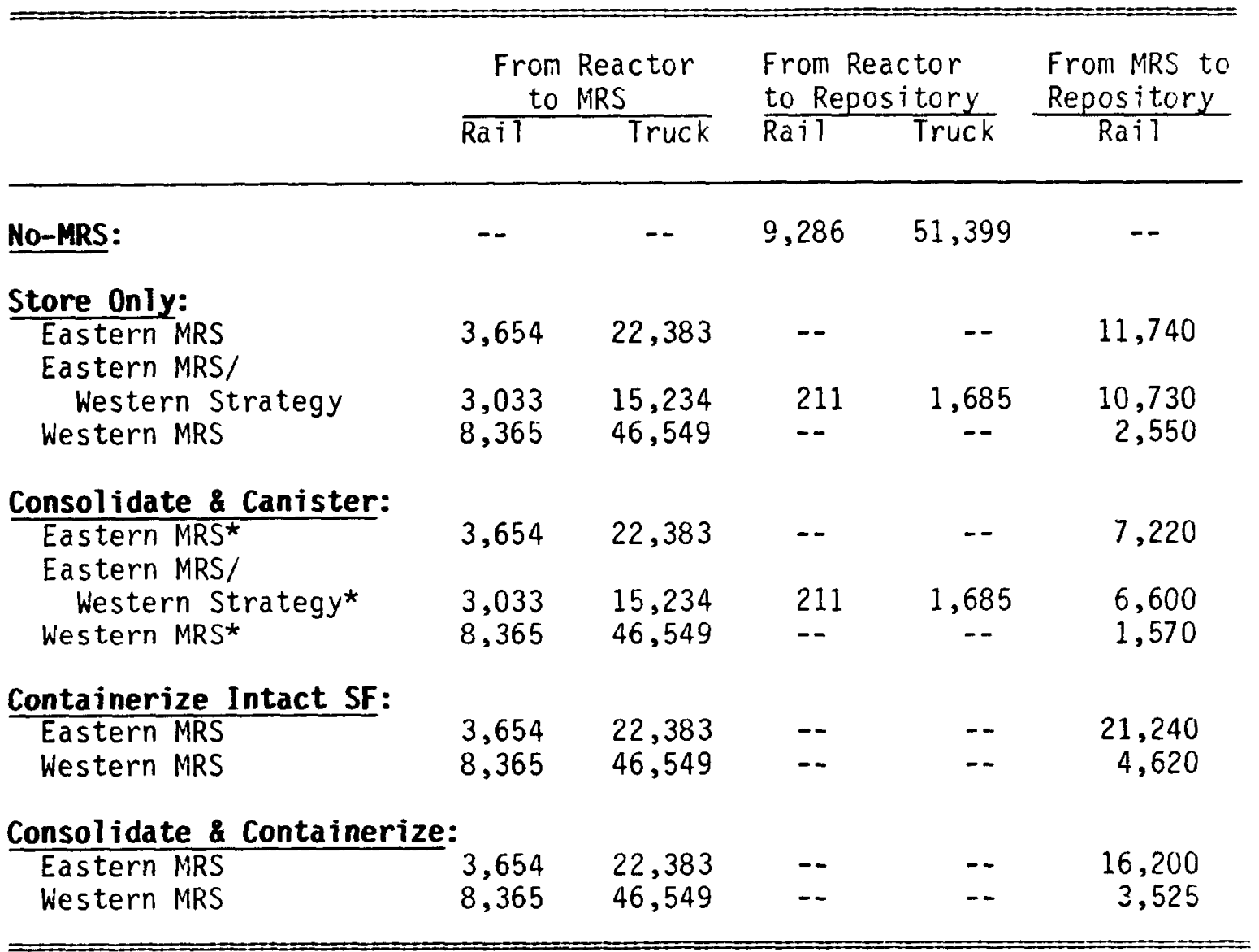

* Includes only spent fuel casks. The two NFBC casks per shipment are not included.

60 million and 57 to 60 million, respectively) and serve as a proxy to the total dose estimates reported in Table 12. Again, it can be seen that fromreactor transport measured in cask-miles is strictly a function of MRS location and Western strategy. As shown in Table 19, variations in cask-miles from an MRS (like variations in shipment-miles) are due to packaging function and MRS location. For Eastern MRS-to-repository shipments, the number of cask-miles is between $22 \%$ and $45 \%$ of the total cask-miles for all 11 SF cases.

The MTU-miles reported in Table 14 are calculated as the quantity of fuel shipped from each facility multiplied by the one-way distance from that facility to an MRS/repository. The detailed estimates of MTU-miles presented in Table 18 indicate that MRS location and Western strategy are the only two sources of variation in MTU-miles.

The calculation of cask days in transit is reported in Table 14 . Cask days in transit is calculated by multiplying the number of cask loads required to transport an annual given amount of waste by the number of days that the loaded cask is in transit. For from-reactor transportation, cask days in transit is calculated on an annual basis for each reactor and then totaled. 
Table 20. MTU-Miles by Transportation Link (1,000s)

for 24-Year Shipping Campaign (Spent Fuel Cases)

\begin{tabular}{|c|c|c|c|c|c|}
\hline & \multicolumn{2}{|c|}{$\begin{array}{l}\text { From Reactor } \\
\text { to MRS }\end{array}$} & \multicolumn{2}{|c|}{$\begin{array}{l}\text { From Reactor } \\
\text { to Repository }\end{array}$} & $\begin{array}{l}\text { From MRS to } \\
\text { Repository } \\
\text { Rail }\end{array}$ \\
\hline No-MRS: & -- & -- & 84,032 & 64,653 & -- \\
\hline \multicolumn{6}{|l|}{ Store Only: } \\
\hline $\begin{array}{l}\text { Eastern MRS } \\
\text { Eastern MRS/ }\end{array}$ & 33,082 & 27,525 & -- & -- & 181,796 \\
\hline $\begin{array}{l}\text { Western Strategy } \\
\text { Western MRS }\end{array}$ & $\begin{array}{l}27,560 \\
75,564\end{array}$ & $\begin{array}{l}18,865 \\
58,462\end{array}$ & $\begin{array}{l}1,909 \\
--\end{array}$ & $\begin{array}{c}2,070 \\
\ldots\end{array}$ & $\begin{array}{r}166,213 \\
39,565\end{array}$ \\
\hline \multicolumn{6}{|c|}{ Consolidate \& Canister: } \\
\hline $\begin{array}{l}\text { Eastern MRS } \\
\text { Eastern MRS/ }\end{array}$ & 33,082 & 27,525 & -- & -- & 181,796 \\
\hline $\begin{array}{l}\text { Western Strategy } \\
\text { Western MRS }\end{array}$ & $\begin{array}{l}27,560 \\
75,564\end{array}$ & $\begin{array}{l}18,865 \\
58,462\end{array}$ & 1,909 & $\begin{array}{c}2,070 \\
--\end{array}$ & $\begin{array}{r}166,213 \\
39,565\end{array}$ \\
\hline \multicolumn{6}{|c|}{ Containerize Intact SF: } \\
\hline $\begin{array}{l}\text { Eastern MRS } \\
\text { Western MRS }\end{array}$ & $\begin{array}{l}33,082 \\
75,564\end{array}$ & $\begin{array}{l}27,525 \\
58,462\end{array}$ & -- & -- & $\begin{array}{r}181,796 \\
39,565\end{array}$ \\
\hline \multicolumn{6}{|c|}{ Consolidate \& Containerize: } \\
\hline $\begin{array}{l}\text { Eastern MRS } \\
\text { Western MRS }\end{array}$ & $\begin{array}{l}33,082 \\
75,564\end{array}$ & $\begin{array}{l}27,525 \\
58,462\end{array}$ & $\begin{array}{l}-- \\
--\end{array}$ & -- & $\begin{array}{r}181,796 \\
39,565\end{array}$ \\
\hline
\end{tabular}

For MRS-to-repository transportation, estimates are calculated on an annual basis and then summed over the 24 years of MRS-to-repository shipping.

The number of shipment days in transit, presented in Table 14, is calculated by dividing the cask days in transit by the number of casks per shipment for each transportation link. The average number of shipments in transit for a typical day during the spent fuel transportation campaign, also shown in Table 14, is calculated by dividing the total number of shipments by the total number of days in the shipping campaign. As expected, the average number of shipments in transit per day for an Eastern MRS system is approximately half of the corresponding number of shipments in transit for the no-MRS or Western MRS system. A similar pattern can be seen for shipment-days in transit and caskdays in transit, following a pattern that is also seen in estimates of total dose. This reflects the elimination of truck and 100-ton rail cask shipments from reactors across the country to the repository or Western MRS.

\subsection{HIGH-LEVEL WASTE CASES}

The results of the transportation analysis of HLW cases are presented in this section. As noted previously, three cases are analyzed in this study, representing the three transportation networks involved: 
- HLW shipped through an Eastern MRS

- HLW shipped through a Western MRS

- HLW shipped directly to the repository.

The transportation impacts calculated and presented in Table 21 for HLW cases include number of shipments, shipment-miles, cask-miles, MTU-miles, and cost. Transportation dose is not included because HLW unit-risk factors have not yet been generated in a manner consistent with the SF unit-risk factors used in this study.

When HLW is shipped through the MRS, the number of HLW shipments increases because each shipment to the repository is broken down into two shorter shipments, one from the HLW site to the MRS, and one from the MRS to the repository. Because of the higher capacity of the from-MRS HLW cask, however, the increase is less than two-fold. This pattern holds for the other measures of transportation activity--shipment-miles, cask-miles, and MTU-miles--as well as for cost.

The controlling factor for HLW impacts is the diversity of location of the HLW sites relative to the generic Eastern MRS, the generic Western MRS, and the repository. An Eastern MRS noticeably increases the transportation activity, and consequently the cost, because it causes over half of the HLW (54\%) which is generated in the West, to be shipped across the country to the MRS in the east, and then again to be hauled back to the repository in the west. Table 22, which shows the distances from each of the four HLW sites to the repository directly and through the generic Eastern and Western MRSs, illustrates this point. The mileage from the two Western HLW sites (Idaho Chemical Processing Plant and Hanford) through the Eastern MRS to the repository is five to seven times higher than the direct distance to the repository. This mileage increase, combined with the aforementioned increase in the number of shipments results in doubling of the shipment-miles and costs of transportation, see Table 21, when an Eastern MRS is used. The effects to shipment-miles and cost are smaller because the mileage increase is smaller.

The net effect is that the cost for transportation of HLW is lowest for a FWMS without an MRS, followed by a FWMS with an MRS in the West.

\subsection{COMPARISON WITH PREVIOUS DOE ANALYSES}

An evaluation of the MRS was completed by the DOE in November 1987 (Ref. 7). The purpose was to provide additional information to address issues raised by the General Accounting office and others "concerning the need for an MRS facility and the feasibility of achieving comparable performance for the overall waste management system without an MRS facility." Sections 4.3 .1 and 4.3.2 provide a comparison between this earlier study and the transportation results presented above. The comparison is limited to spent fuel results only, as the previous study did not evaluate HLW.

\subsubsection{No-MRS System}

The November 1987 report examined a Reference No-MRS system and five Alternative No-MRS systems. The alternative systems explored scenarios with different cask capacity assumptions as well as scenarios with varying amounts 
Table 21. Transportation Life-Cycle Cost and Measures of Activity High-Level Waste Cases

\begin{tabular}{|c|c|c|c|c|c|}
\hline & $\begin{array}{l}\text { Number of } \\
\text { Shipments }\end{array}$ & $\begin{array}{l}\text { Shipment } \\
\text { Miles } \\
(1,000 \mathrm{~s})\end{array}$ & $\begin{array}{l}\text { Cask } \\
\text { Miles } \\
(1,000 \mathrm{~s})\end{array}$ & $\begin{array}{l}\text { MTU } \\
\text { Miles } \\
(1,000 \mathrm{~s})\end{array}$ & $\begin{array}{l}\text { Total } \\
\text { Cost } \\
\text { (\$million) }\end{array}$ \\
\hline Shipments to Repository & 560 & 1,076 & 5,378 & 13,444 & 172 \\
\hline $\begin{array}{l}\text { Shipments through Eastern MRS: } \\
\text { To Eastern MRS } \\
\text { MRS to Repository }\end{array}$ & $\begin{array}{l}960 \\
560 \\
400\end{array}$ & $\begin{array}{r}2,028 \\
874 \\
1,154\end{array}$ & $\begin{array}{r}10,140 \\
4,369 \\
5,771\end{array}$ & $\begin{array}{l}31,122 \\
10,922 \\
20,200\end{array}$ & $\begin{array}{l}343 \\
148 \\
195\end{array}$ \\
\hline $\begin{array}{l}\text { Shipments through Western MRS: } \\
\text { To Western MRS } \\
\text { MRS to Repository }\end{array}$ & $\begin{array}{l}960 \\
560 \\
400\end{array}$ & $\begin{array}{r}1,238 \\
987 \\
251\end{array}$ & $\begin{array}{l}6,191 \\
4,936 \\
1,256\end{array}$ & $\begin{array}{r}16,734 \\
12,339 \\
4,396\end{array}$ & $\begin{array}{r}237 \\
161 \\
76\end{array}$ \\
\hline
\end{tabular}


Table 22. Distances (Miles) From High-Level Waste Sites

\begin{tabular}{lccc}
\hline HLW Site & \multicolumn{3}{c}{ Distance to Repository } \\
\cline { 2 - 4 } & $\begin{array}{c}\text { Direct to } \\
\text { Repository }\end{array}$ & $\begin{array}{c}\text { Through Generic } \\
\text { Eastern MRS }\end{array}$ & $\begin{array}{c}\text { Through Generic } \\
\text { Western MRS }\end{array}$ \\
\hline West Valley & 2,652 & 3,382 & 3,075 \\
Savannah River & 2,763 & 3,618 & 3,295 \\
$\begin{array}{l}\text { Idaho Chemical } \\
\text { Processing Plant }\end{array}$ & 756 & 5,339 & 1,213 \\
Hanford & 1,302 & 5,885 & 1,622 \\
\hline
\end{tabular}

of at-reactor consolidation. However, the varying amounts of at-reactor consolidation are beyond the scope of the present analysis; comparison with the present analysis is limited to the Reference No-MRS system.

The previous study reported a total of 39,300 (Ref. 6, Table A-4.6) shipments, comprising 33,500 shipments by truck and 5,800 shipments by rail. This compares with 23,836 shipments in the present report (Table 14), comprising 22,550 truck shipments and 1,286 rail shipments (Table 17). The following factors explain the differences in number of shipments:

- Total quantity of SF shipped in the previous study was 65,360 MTU, compared to 63,000 MTU in the present analysis.

- The capacity of from-reactor rail casks was assumed to be 14 PWR or 36 BWR assemblies, compared to 21 PWR or 48 BWR assumed in the present work.

- The capacity of from-reactor truck casks was assumed to be 2 PWR or 5 BWR assemblies, compared to 3 PWR or 7 BWR assumed in the present work.

- The previous study assumed that all from-reactor shipments are made as single cask/vehicle units in general freight service whereas in the present work, it is assumed that rail shipments from reactors are made in dedicated trains of three casks.

1 Appendix $A$ addresses the assumption of 3 casks per dedicated train and explains the cost assumptions/algorithms. This assumption provides a conservative estimate of transportation costs for the FWMS. The eventual use or nonuse of dedicated trains to transport NWPA waste will be determined as a result of cost, risk, logistical, and institutional analyses to be performed later. 
rail shipments from reactors are made in dedicated trains of three casks.

The previous study reported 67 million shipment-miles by truck (Ref. 7 , Table A-4.6), compared to 51 million in the present work (Table 18). This difference is accounted for by the different capacity and dedicated train assumptions noted above. Rail shipment-miles were reported at 13 million, compared with 3 million in the present study. (Note that in the previous study, shipment-miles are synonymous with cask-miles.) This difference is explained by the larger capacity rail casks and the assumption of three casks per shipment in the present work, as noted above. In addition, distance calculations in the previous study were made on a "point-to-point basis using the methodology developed for the WASTES program" (Ref. 6, Sec. A.3, p. A-6). In the present study, distances were generated using the HIGHWAY and INTERLINE computer programs (Refs. 4 and 5). The difference in these methods may explain some variation in the results, although it cannot be demonstrated on the basis of information available from the previous report.

The total transportation costs were reported in the previous study at $\$ 1,120$ million, compared to $\$ 832$ million in the present analysis, reflecting the differences in assumptions noted above.

\subsubsection{MRS System}

The Reference MRS System of the previous study (Ref. 6, Table A-4.11) was used as the basis for comparison with this report. That study used the same differing assumptions for the from-reactor shipments that are listed in the preceding discussion. Differences in from-reactor shipment results for the MRS System case have been addressed in the preceding discussion. Both analyses assumed that the MRS consolidates and canisters the spent fuel. The results for from-MRS shipments are similar in that both studies report around 500 ship-. ments from the MRS. However, in comparing the two studies, the from-MRS shipment-miles are noticeably different (the previous study reports 1 million shipment-miles and this study indicates about 1.4 million shipment-miles for transportation from the MRS to repository). This difference is attributable to different estimates of rail distance from the MRS to the repository. This report uses a generic Eastern MRS with a rail distance of 2,885 miles to the repository, whereas the previous study used the Clinch River MRS site near Oak Ridge, Tennessee. The previous study reported a total transportation cost of $\$ 893$ million, compared to $\$ 718$ million in this report for the generic Eastern location. 


\subsection{SENSITIVITY ANALYSES}

Four sets of sensitivity analyses were conducted for this study to provide additional insights into the transportation impacts reported in earlier sections of this report. The purpose of the first sensitivity is to further examine the impact of MRS location on spent nuclear fuel transportation, using the six regional centroids (see Figure 2) as hypothetical MRS locations. The second sensitivity analysis further addresses this issue by examining the transportation costs associated with an analytically selected MRS site which approximates a minimum shipment-mile location. The third sensitivity examines the impact of replacing the legal-weight truck (LWT) with overweight truck (OWT) casks for shipments from reactors. The fourth sensitivity analysis examines whether variations in spent fuel transportation cask capacities affect the relative comparison of MRS packaging and location options.

\subsection{SENSITIVITY ANALYSIS - SIX MRS CENTROID LOCATIONS}

Transportation impacts were calculated for the six hypothetical centroids identified in Figure 2 in Chapter 4 . Each centroid was evaluated using the four MRS packaging functions listed below, resulting in a total of 24 cases:

$$
\begin{aligned}
& \text { - Store only } \\
& \text { - Consolidate and canister } \\
& \text { - Containerize intact spent fuel } \\
& \text { - Consolidate and containerize. }
\end{aligned}
$$

The waste acceptance schedule depicted in Table 3 (in Chapter 2) was used for this sensitivity analysis. The resulting estimates of cost, dose, shipment-miles, cask-miles, and MTU-miles are presented in Tables 23 through 29.

It can be observed from Table 23 that the largest cost difference within a specific packaging function occurs in the case of a MRS that containerizes intact spent fuel. In this case, the cost difference is $\$ 185$ million between Centroid 2 (\$962 million) and Centroid 6 (\$1,147 million). In general, the Western centroids (Centroids 1 and 2) have higher total dose in the range of 2,400 to 2,600 person-rem. By comparison, the two Eastern centroids (Centroids 5 and 6) exhibit total doses in the range of 1,500 to 2,000 person-rem. The central centroids fall between these extremes, as expected. These differences, particularly between Eastern and Western centroids, result primarily because of the large increase in shipment-miles traveled by Western fuel traveling to the Eastern MRS site and then back to the Western repository.

Table 24 presents the results for total shipment-miles, cask-miles, and MTU-miles. Note that shipment numbers are not reported in this table because they are identical to those reported earlier in Table 14 . Note also that, as expected, MTU-miles vary only with the centroid location and not with packaging function. The Western centroids (Centroids 1 and 2) have higher cask-miles and shipment-miles than the Eastern centroids, as would be expected, because the smaller capacity from-reactor casks travel over longer distances.

These data are also presented at the disaggregated level, i.e., by transportation link, in Tables 25 through 29. 
Table 23. Summary of Transportation Cost and Dose by MRS Location Sensitivity Cases - Six MRS Centroids

\begin{tabular}{lcc} 
& Total & Total \\
Cost & Dose \\
Cases & $(\$ m i l l i o n s)$ & $(1000$ person-rem $)$ \\
\hline
\end{tabular}

Store Only:

Centroid 1

Centroid 2

Centroid 3

Centroid 4

Centroid 5

Centroid 6
909

882

780

816

821

847

866

856

706

735

710

724
2.4

2.6

1.9

1.8

1.6

1.7

\section{Consolidate \& Canister:}

Centroid 1

Centroid 2

Centroid 3

Centroid 5

Centroid 6

Containerize Intact SF:

$\begin{array}{ll}\text { Centroid } & 1 \\ \text { Centroid } & 2 \\ \text { Centroid } & 3 \\ \text { Centroid } & 4 \\ \text { Centroid } & 5 \\ \text { Centroid } & 6\end{array}$
1,027

962

970

1,021

1,092

1,147
2.4

2.6

1.8

1.7

1.5

1.6

\section{Consolidate \& Containerize:}

Centroid 1

Centroid 2

Centroid 3

Centroid 4

Centroid 5

Centroid 6
963

919

867

910

945

985
2.5

2.6

2.1

2.0

1.9

2.0 
Table 24. Measures of Transportation Activity -

Sensitivity Cases - Six MRS Centroids

$\begin{array}{llll} & \text { Shipment } & \text { Cask } & \text { MTU } \\ \text { Miles } & \text { Miles } & \text { Miles } \\ \text { Cases } & \left(1000^{\prime} s\right) & \left(1000^{\prime} s\right) & \left(1000^{\prime} s\right) \\ & & & \\ & & \end{array}$

Store Only:

Centroid 1

Centroid 2

Centroid 3

Centroid 4

Centroid 5

Centroid 6
49,822

49,876

32,272

31,876

26,279

25,619
57,923

57,015

40,806

41,273

37,313

38,236
184,042

163,145

184,592

198,365

229,335

255,488

\section{Consolidate \& Canister:}

Centroid 1

Centroid 2

Centroid 3

Centroid 4

Centroid 5

Centroid 6
49,560

49,745

31,742

31,290

25,433

24,657
56,612

56,358

38,159

38,342

33,085

33,424
184,042

163,145

184,592

198,365

229,335

255,488

\section{Containerize Intact SF:}

Centroid 1

Centroid 2

Centroid 3

Centroid 4

Centroid 5

Centroid 6
50,373

50,152

33,385

33,109

28,056

27,642
60,679

58,395

46,370

47,436

46,201

48,352
184,042

163,145

184,592

198,365

229,335

255,488

\section{Consolidate \& Containerize:}

Centroid 1

Centroid 2

Centroid 3

Centroid 4

Centroid 5

Centroid 6
50,081

50,005

32,794

32,455

27,113

26,658
59,216

57,663

43,417

44,165

41,484

42,983
184,042

163,145

184,592

198,365

229,335

255,488 
Table 25. Cost by Transportation Link (\$millions) Sensitivity Cases - Six MRS Centroids

$\begin{array}{lll}\text { From Reactor to MRS } & \text { Truck } & \frac{\text { From MRS to Repository }}{\text { Rail }}\end{array}$

\section{Store Oniy:}

Centroid 1

Centroid 2

Centroid 3

Centroid 4

Centroid 5

Rail Truck

Rail

Centroid 6

234

247

156

166

128

141
519

530

374

381

338

314
156

105

250

269

355

392

\section{Consolidate \& Canister:}

Centroid 1

Centroid 2

Centroid 3

Centroid 4

Centroid 5

Centroid 6
234

247

156

166

128

141
519

530

374

381

338

314
113

79

176

188

244

269

\section{Containerize Intact:}

Centroid 1

Centroid 2

Centroid 3

Centroid 4

Centroid 5

Centroid 6
234

247

156

166

128

141
519

530

374

381

338

314
274

185

440

474

626

692

\section{Consolidate \& Containerize:}

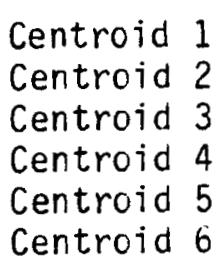

Centroid 1

234

247

156

166

128

141
519

530

374

381

338

314
210

142

337

363

479

530 
Table 26. Dose by Transportation Link (1,000s person-rem) Sensitivity Cases - Six MRS Centroids

$\begin{array}{lll}\text { Case } & \text { From Reactor to MRS } & \text { From MRS to Repository } \\ \text { Rail Truck } & \frac{\text { Rail }}{2}\end{array}$

\section{Store Only:}

$\begin{array}{llll}\text { Centroid 1 } & 0.7 & 1.6 & 0.1 \\ \text { Centroid 2 } & 0.7 & 1.8 & 0.1 \\ \text { Centroid 3 } & 0.5 & 1.1 & 0.2 \\ \text { Centroid 4 } & 0.5 & 1.1 & 0.2 \\ \text { Centroid 5 } & 0.4 & 0.9 & 0.3 \\ \text { Centroid 6 } & 0.4 & 0.9 & 0.3\end{array}$

Consolidate \& Canister:

$\begin{array}{llll}\text { Centroid } 1 & 0.7 & 1.6 & 0.8 \\ \text { Centroid 2 } & 0.7 & 1.8 & 0.1 \\ \text { Centroid 3 } & 0.5 & 1.1 & 0.1 \\ \text { Centroid } 4 & 0.5 & 1.1 & 0.1 \\ \text { Centroid } 5 & 0.4 & 0.9 & 0.2 \\ \text { Centroid } 6 & 0.4 & 0.9 & 0.2\end{array}$

Containerize Intact:

Centroid 1

Centroid 2

Centroid 3

Centroid 4

Centroid 5

Centroid 6
0.7

0.7

0.5

0.5

0.4

0.4
1.6

1.8

1.1

1.1

0.9

0.9
0.2

0.1

0.4

0.4

0.6

0.6

\section{Consolidate \& Containerize:}

$\begin{array}{llll}\text { Centroid 1 } & 0.7 & 1.6 & 0.2 \\ \text { Centroid 2 } & 0.7 & 1.8 & 0.1 \\ \text { Centroid 3 } & 0.5 & 1.1 & 0.3 \\ \text { Centroid 4 } & 0.5 & 1.1 & 0.3 \\ \text { Centroid 5 } & 0.4 & 0.9 & 0.5 \\ \text { Centroid 6 } & 0.4 & 0.9 & 0.5\end{array}$


Table 27. Shipment-Miles by Transportation Link (1,000s) Sensitivity Cases - Six MRS Centroids

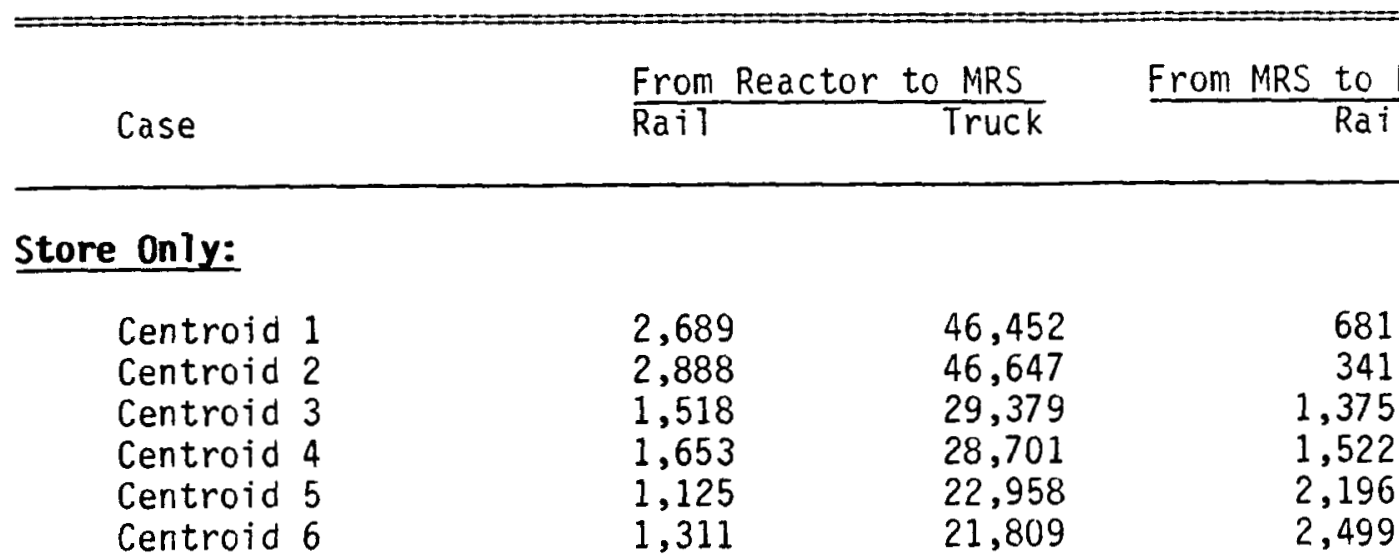

Consolidate \& Canister:

$\begin{array}{llll}\text { Centroid 1 } & 2,689 & 46,452 & 419 \\ \text { Centroid 2 } & 2,888 & 46,647 & 210 \\ \text { Centroid 3 } & 1,518 & 29,379 & 845 \\ \text { Centroid } 4 & 1,653 & 28,701 & 936 \\ \text { Centroid 5 } & 1,125 & 22,958 & 1,350 \\ \text { Centroid 6 } & 1,311 & 21,809 & 1,537\end{array}$

Containerize Intact SF:

Centroid 1

Centroid 2

Centroid 3

Centroid 4

Centroid 5

Centroid 6
2,689

2,888

1,518

1,653

1,125

1,311
46,452

46,647

29,379

28,701

22,958

21,809
1,232

617

2,488

2,755

3,973

4,522

Consolidate \& Containerize:

Centroid 1

Centroid 2

Centroid 3

Centroid 4

Centroid 5

Centroid 6
2,689

2,888

1,518

1,653

1,125

1,311
46,452

46,647

29,379

28,701

22,958

21,809
940

470

1,897

2,101

3,030

3,448 
Table 28. Cask-Miles by Transportation Link (1,000s)

Sensitivity Cases - Six MRS Centroids

\begin{tabular}{lll} 
Case & $\frac{\text { From Reactor to MRS }}{\text { Rail }}$ & $\frac{\text { From MRS to Repository }}{\text { Rail }}$ \\
\hline
\end{tabular}

Store Only:

$\begin{array}{lrrr}\text { Centroid 1 } & 8,066 & 46,452 & 3,405 \\ \text { Centroid 2 } & 8,664 & 46,647 & 1,704 \\ \text { Centroid 3 } & 4,553 & 29,379 & 6,874 \\ \text { Centroid 4 } & 4,960 & 28,701 & 7,612 \\ \text { Centroid 5 } & 3,376 & 22,958 & 10,979 \\ \text { Centroid 6 } & 3,932 & 21,809 & 12,495\end{array}$

Consolidate \& Canister:

$\begin{array}{llll}\text { Centroid 1* } & 8,066 & 46,452 & 2,094 \\ \text { Centroid 2* } & 8,664 & 46,647 & 1,047 \\ \text { Centroid 3* } & 4,553 & 29,379 & 4,227 \\ \text { Centroid 4* } & 4,960 & 28,701 & 4,681 \\ \text { Centroid 5* } & 3,376 & 22,958 & 6,751 \\ \text { Centroid 6* } & 3,932 & 21,809 & 7,683\end{array}$

Containerize Intact SF:

Centroid 1

Centroid 2

Centroid 3

Centroid 4

Centroid 5

Centroid 6
8,066

8,664

4,553

4,960

3,376

3,932
46,452

46,647

29,379

28,701

22,958

21,809
6,161

3,084

12,438

13,775

19,867

22,611

\section{Consolidate \& Containerize:}

Centroid 1

Centroid 2

Centroid 3

Centroid 4

Centroid 5

Centroid 6
8,066
8,664
4,553
4,960
3,376
3,932

46,452

46,647

29,379

28,701

22,958

21,809
4,698

2,352

9,485

10,504

15,150

17,242

*Includes only spent fuel casks. The two MFBC casks per shipment from the MRS are not included. 
Table 29. MTU-Miles by Transportation Link (1,000s)

Sensitivity Cases - Six MRS Centroids

Case $\frac{\text { From Reactor to MRS }}{\text { RaiT }} \quad \frac{\text { From MRS to Repository }}{\text { Rail }}$

Store Only:

$\begin{array}{lrrr}\text { Centroid 1 } & 72,918 & 58,386 & 52,738 \\ \text { Centroid 2 } & 78,209 & 58,539 & 26,397 \\ \text { Centroid 3 } & 41,278 & 36.842 & 106,472 \\ \text { Centroid 4 } & 44,641 & 35,811 & 117,913 \\ \text { Centroid 5 } & 30,810 & 28.467 & 170,058 \\ \text { Centroid 6 } & 35,354 & 26,582 & 193,552\end{array}$

Consolidate \& Canister:

Centroid 1

Centroid 2

Centroid 3

Centroid 4

Centroid 5

Centroid 6
72,918

78,209

41,278

44,641

30,810

35,354

Containerize Intact SF:

Centroid 1

Centroid 2

Centroid 3

Centroid 4

Centroid 5

Centroid 6

72,918

78,209

41,278

44,641

30,810

35,354
Consolidate \& Containerize:

Centroid 1

Centroid 2

Centroid 3

Centroid 4

Centroid 5

Centroid 6
72,918

78,209

41,278

44,641

30,810

35,354
58,386

58,539

36,842

35,811

28,467

26,582

58,386

58,539

36,842

35,811

28,467

26,582

58,386

58,539

36,842

35,811

28,467

26,582
52,738

26,397

106,472

117,913

170,058

193,552
52,738

26,397

106,472

117,913

170,058

193,552 


\subsection{SENSITIVITY ANALYSIS - MINIMUM SHIPMENT-MILE LOCATION}

To further understand the sensitivity of transportation cost and dose to location, a minimum shipment-mile location was developed. A number of arbitrary points within an area bounded by 36 and 40 degrees north latitude and 79 and 85 degrees west longitude were selected as hypothetical MRS locations. The selection of the area was based on the previous MRS study (Ref. 6), the six centroid sensitivity assessments described in the previous section, and the high density of Eastern reactors.

For each hypothetical location within the selected area, the total number of shipment-miles was estimated. It was assumed that the MRS packaging function was the MRS consolidate and canister configuration. Mileage estimates from reactors to the MRS and from the MRS to repository were developed by identifying the corresponding shortest distance connecting each origin/destination pair on the spherical surface of the earth. With an estimate of total shipment-miles calculated for each hypothetical MRS location, the area resulting in the minimum number of shipment-miles was identified in the mid-Atlantic region, an area approximated by 38 degrees north latitude and 81 degrees west longitude. The nearest common node, in the HIGHWAY and INTERLINE data bases, was then used to calculate route-specific data for the truck and rail distances that were the basis for generating the life-cycle costs.

The transportation costs corresponding to the minimum shipment-miles MRS location that consolidates and canisters spent fuel are given in Table 30 . Additional costs were calculated for this MRS location assuming different packaging functions and are also given in Table 30 . The number of shipments, shipment-miles, and cask-miles for each packaging function of the minimum shipment-miles MRS location are provided in Tables 31 to 33.

The results indicate that a store-only MRS and an MRS that consolidates and canisters have a lower cost than the reference no-MRS case. Cost savings range from $\$ 93$ million for the MRS store-only case to $\$ 267$ million for the MRS consolidate-and-canister with Western strategy case.

The minimum shipment-mile MRS location results in smaller total cost than the generic Eastern MRS location for all packaging functions as shown by comparing the values in Table 30 to the corresponding numbers in Table 12 . The differences, ranging from approximately $\$ 80$ to $\$ 120$ million, are a direct consequence of the decrease in the shipment-miles involved in the minimum shipment-miles location. For example, both the cost and the shipment-miles for the consolidate-and-canister case of the minimum shipment-miles location are reduced by the similar amounts (13 to 14\%) from the corresponding values of the generic Eastern MRS.

The shipment-miles difference between the minimum shipment-miles location and the generic Eastern MRS is a direct consequence of the difference in the average distance from the reactors to the MRS and from the MRS to the repository. The average reactor to MRS distances for the minimum shipment-miles location and the generic Eastern MRS are approximately 870 and $990 \mathrm{miles,}$

1 These average distances are obtained by dividing the shipment-miles by the number of shipments. 
Table 30. Cost by Transportation Link (\$millions)

Minimum Shipment-Miles MRS Location - Spent Fuel Cases

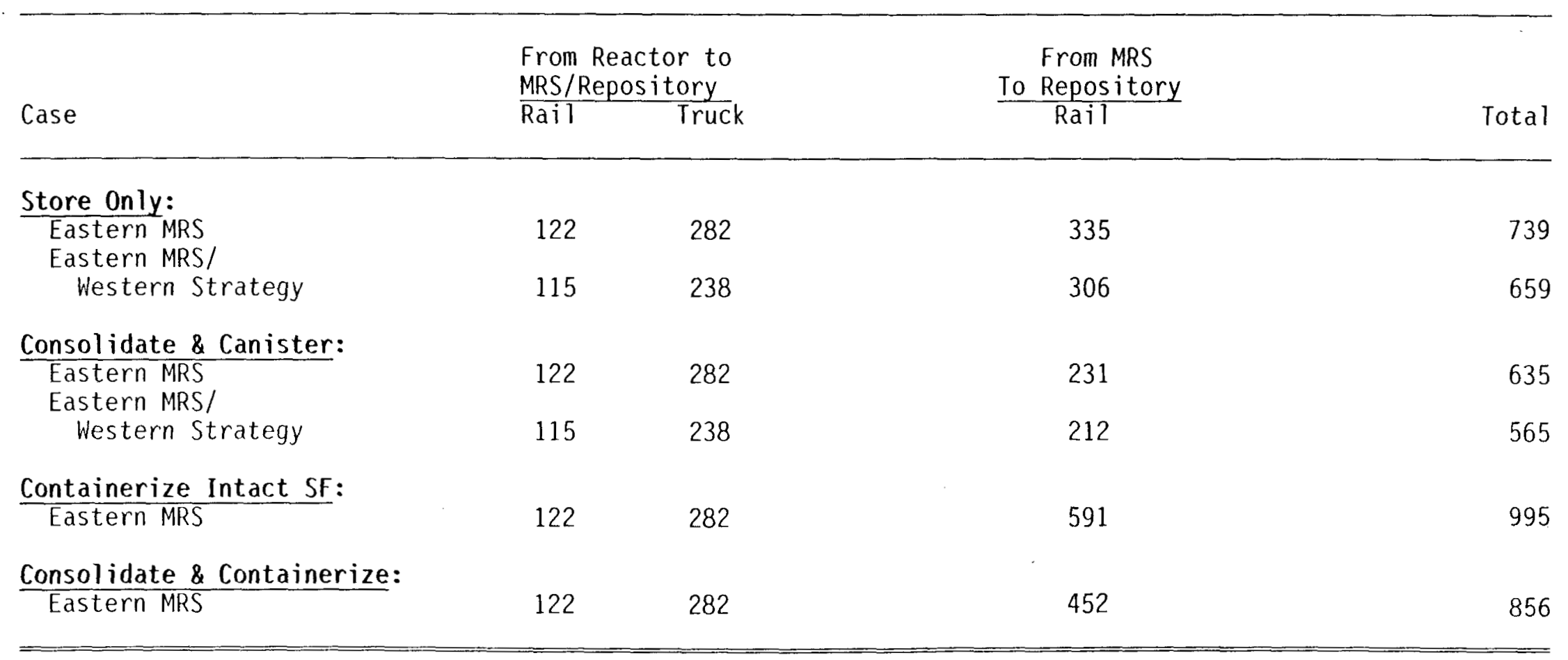


Table 31. Number of Shipments by Transportation Link

Minimum Shipment-Miles MRS Location - Spent Fuel Cases

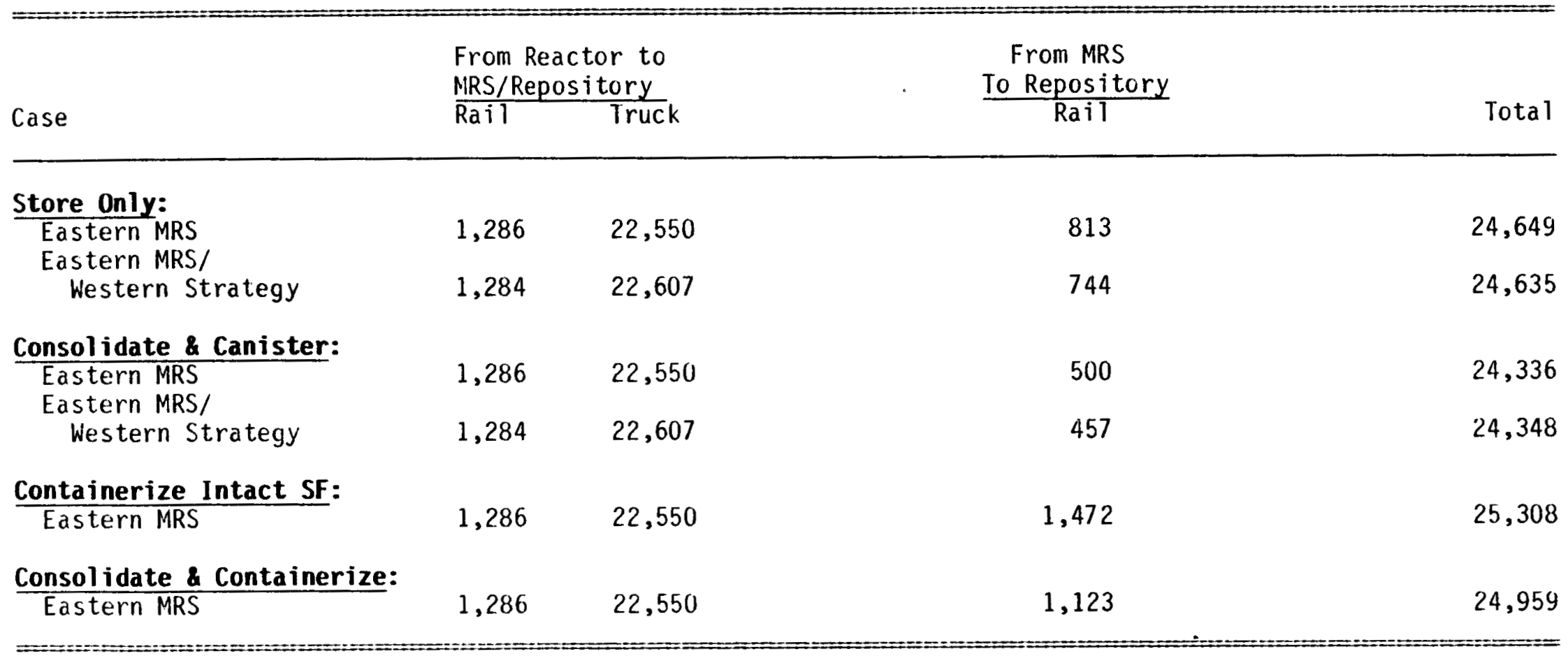


Table 32. Shipment-Miles by Transportation Link (1,000s)

Minimum Shipment-Miles MRS Location - Spent Fuel Cases

\begin{tabular}{|c|c|c|c|c|}
\hline Case & \multicolumn{2}{|c|}{$\begin{array}{l}\text { From Reactor to } \\
\text { MRS/Repository }\end{array}$} & $\begin{array}{c}\text { From MRS } \\
\frac{\text { To Repository }}{\text { Rail }}\end{array}$ & Total \\
\hline \multicolumn{5}{|l|}{ Store Only: } \\
\hline $\begin{array}{l}\text { Eastern MRS } \\
\text { Eastern MRS/ }\end{array}$ & 1,035 & 19,681 & 2,038 & 22,754 \\
\hline Western Strategy & 923 & 14,860 & 1,863 & 17,676 \\
\hline \multicolumn{5}{|c|}{ Consolidate \& Canister: } \\
\hline $\begin{array}{l}\text { Eastern MRS } \\
\text { Eastern MRS/ }\end{array}$ & 1,035 & 19,681 & 1,253 & 21,969 \\
\hline Western Strategy & 923 & 14,860 & 1,146 & 16,929 \\
\hline \multicolumn{5}{|c|}{ Containerize Intact SF: } \\
\hline Eastern MRS & 1,035 & 19,681 & 3,688 & 24,404 \\
\hline \multicolumn{5}{|c|}{ Consolidate \& Containerize: } \\
\hline Eastern MRS & 1,035 & 19,681 & 2,813 & 23,529 \\
\hline
\end{tabular}


Table 33. Cask-Miles by Transportation Link (1,000s)

Minimum Shipment-Miles MRS Location - Spent Fuel Cases

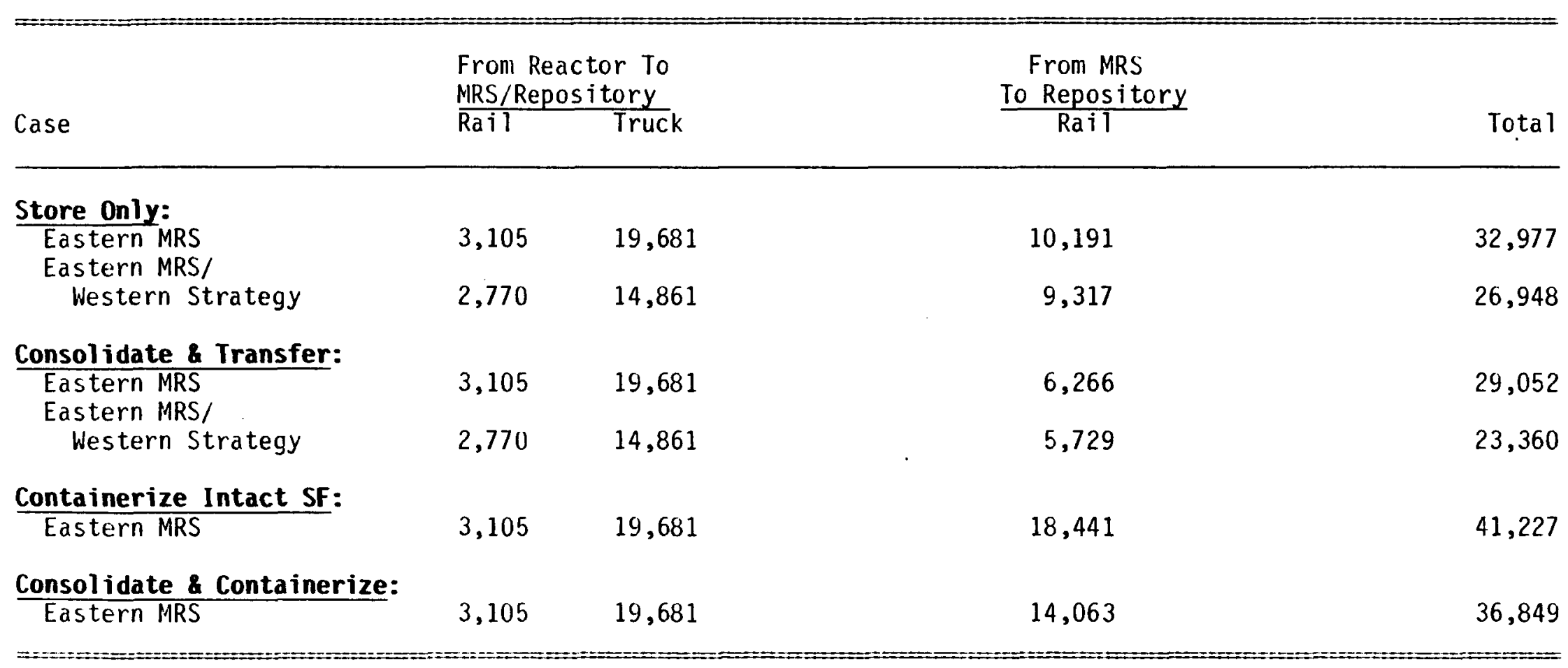


respectively. Similarly, the MRS to repository average distances are 2,505 and 2,885 miles, i.e., the minimum shipment-miles location is 380 miles closer to the repository than the generic Eastern MRS.

\subsection{SENSITIVITY ANALYSIS - OVERWEIGHT TRUCK}

Shipment of spent fuel from truck-served reactors in overweight truck (OWT) casks has been cited as an option for reducing the number of truck shipments (and hence cost and dose). The use of OWT is not certain at this time due to unresolved legal, operational, and institutional issues. However, a sensitivity analysis was conducted for OWT casks using the following cases:

- All truck shipments directly to repository

- All truck shipments to generic Eastern MRS

- Al1 truck shipments to generic Western MRS

- Truck shipments from Eastern reactors to generic Eastern MRS; from Western reactors to repository.

Note that this sensitivity analysis affects only the cost and dose associated with from-reactor truck shipments. All other impacts are unchanged.

The results of this sensitivity analysis are presented in Table 34 . In terms of cost, the use of OWT leads to cost savings ranging from $\$ 82$ to $\$ 160$ million depending on MRS location and Western strategy. In percentage terms, the cost savings from using OWT are roughly $30 \%$ when compared to LWT.

As can be seen in Table 34, use of the OWT casks leads to about 9,200 fewer shipments as compared to the use of LWT casks, in direct correspondence to the higher capacity of OWT casks. A similar pattern is exhibited in estimates of shipment-miles and cask-miles, which are equal for truck transport.

The reduction in the number of truck shipments by about $40 \%$ results in roughly the same percentage reduction in total dose. As expected, the dose per cask mile for OWT casks is the same as for LWT casks. This is because dose calculations for both casks are based on the regulatory dose limit of 10 mrem per hour at 2 meters from the cask, and therefore dose per cask mile is not a function of cask capacity.

\subsection{SENSITIVITY ANALYSIS - CASK CAPACITIES}

The casks that will eventually be used to transport SF under the OCRWM program are currently in the preliminary or conceptual design phase. As such, their projected capacities could change as the design and fabrication effort progresses. Past analyses have indicated that cask capacity may be the most important determinant of transportation cost and dose. It was not known, however, whether different cask capacities would also affect the relative comparisons of MRS packaging and location options, which are the focus of this study.

To examine this issue, transportation costs and dose estimates for the 11 spent fuel cases (Figure 1) were re-calculated using lower and upper bounding values from cask capacity, as shown in Tables 35 and 36 for from-reactor and from-MRS casks, respectively. 
Table 34. Transportation Cost, Dose, and Measures of Activity

Sensitivity Case - Overweight Truck

\section{Overweight Truck Cask}

\begin{tabular}{|c|c|c|c|c|c|c|}
\hline Case & $\begin{array}{l}\text { MTU-Miles } \\
(1,000 \mathrm{~s})\end{array}$ & $\begin{array}{l}\text { Cask-Miles } \\
(1,000 \mathrm{~s})\end{array}$ & $\begin{array}{l}\text { Shipment-Miles } \\
(1,000 \mathrm{~s})\end{array}$ & $\begin{array}{l}\text { Number of } \\
\text { Shipments }\end{array}$ & $\begin{array}{l}\text { Total Cost } \\
\text { (\$millions) }\end{array}$ & $\begin{array}{cl}\text { Total } & \text { Dose } \\
(1,000 \text { s } & \text { per-rem })\end{array}$ \\
\hline NO-MRS & 64,653 & 30,510 & 30,510 & 13,392 & 412 & 1.2 \\
\hline Eastern MRS & 27,525 & 13,311 & 13,311 & 13,392 & 230 & 0.5 \\
\hline $\begin{array}{l}\text { Eastern MRS/ } \\
\text { Western Strategy }\end{array}$ & 20,930 & 10,047 & 10,047 & 13,425 & 192 & 0.5 \\
\hline Western MRS & 58,462 & 27,641 & 27,641 & 13,392 & 378 & 1.0 \\
\hline & \multicolumn{6}{|c|}{ Legal-Weight Truck Cask } \\
\hline & $\begin{array}{l}\text { MTU-Miles } \\
(1,000 \mathrm{~s})\end{array}$ & $\begin{array}{l}\text { Cask-Miles } \\
(1,000 \mathrm{~s})\end{array}$ & $\begin{array}{l}\text { Shipment-Miles } \\
(1,000 \mathrm{~s})\end{array}$ & $\begin{array}{l}\text { Number of } \\
\text { Shipments }\end{array}$ & $\begin{array}{l}\text { Total Cost } \\
\text { (\$millions) }\end{array}$ & $\begin{array}{cl}\text { Total } & \text { Dose } \\
(1,000 \text { s } & \text { per-rem })\end{array}$ \\
\hline NO-MRS & 64,653 & 51,400 & 51,400 & 22,550 & 572 & 1.9 \\
\hline Eastern MRS & 27,525 & 22,383 & 22,383 & 22,550 & 326 & 0.9 \\
\hline $\begin{array}{l}\text { Eastern MRS/ } \\
\text { Western Strategy }\end{array}$ & 20,935 & 16,920 & 16,920 & 22,607 & 273 & 0.8 \\
\hline Western MRS & 58,462 & 46,550 & 46,550 & 22,550 & 524 & 1.7 \\
\hline
\end{tabular}


Table 35. From-Reactor Cask Capacity

Used for Sensitivity Analysis

\begin{tabular}{lcc}
\hline & \multicolumn{2}{c}{ CASK ID } \\
\cline { 3 - 3 } & & \\
\hline Cask Capacity (PWR/BWR Assemblies) & & \\
Lower & & $2 / 6$ \\
Reference & $16 / 40$ & $3 / 7$ \\
Higher & $21 / 48$ & $4 / 9$ \\
\hline
\end{tabular}

Table 36. From-MRS Cask Capacity Used for Sensitivity Analysis

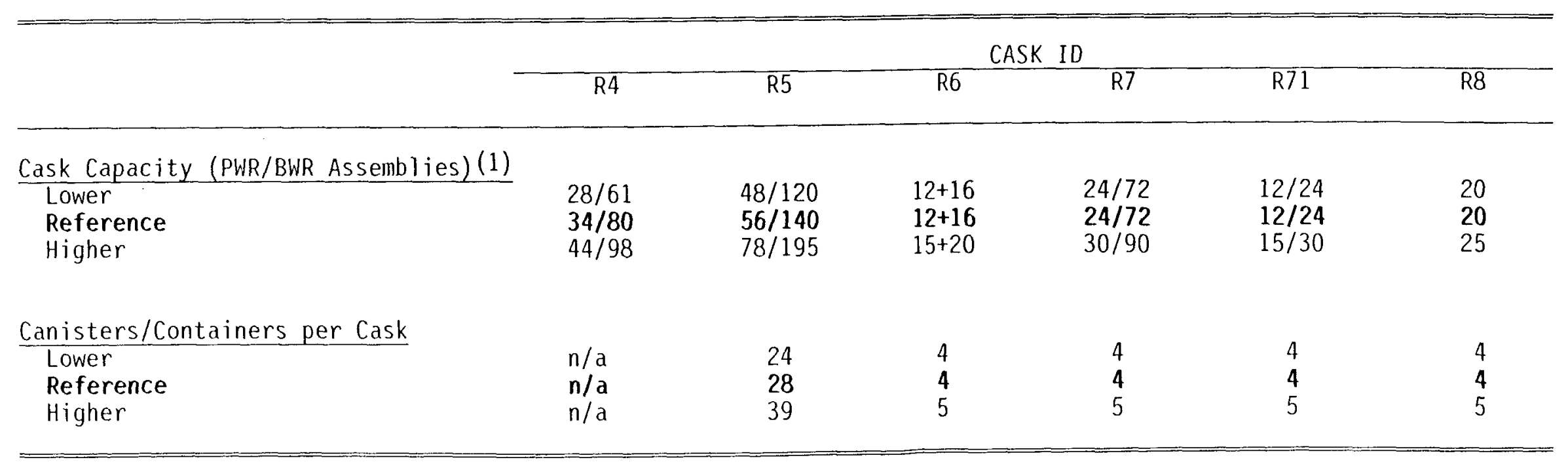

(1) SF cask capacities are stated in PWR/BWR assemblies. NFBC cask capacity is stated in 55-gallon drums. HLW cask capacity is stated in canisters. 
The sensitivity analysis was conducted by assuming that higher (lower) capacities are the result of design improvements (constraints) or different materials (such as steel, lead, depleted uranium). For simplicity, it is further assumed that such capacity changes do not affect loaded or empty cask weights, cask capital costs, and processing times. Further, a major portion of the transportation costs, such as security costs for truck shipments or dedicated train costs for rail shipments, are independent of shipping weight. As a result, small changes in cask empty weight are assumed to have little effect on hauling costs. A major additional assumption for this analysis is that capacity gains resulting from improved analysis/material applications with cask designs of similar complexity leave capital costs for casks unaffected.

The results are shown in Tables 37 through 41 . As expected, lower cask capacities result in systematically higher costs and dose; higher cask capacities similarly result in lower costs and dose. Other salient findings are:

- Containerization at the MRS of intact spent fuel remains the more costly option from a transportation perspective due to low cask capacity.

- An Eastern MRS system generally results in lower transportation costs over the no-MRS system when the MRS packaging function is to consolidate and canister or store only due to reduced shipment-miles.

- The relative rankings of the 11 cases is fairly stable. Thus, there appears to be no compelling reason to qualify the study findings based on the results of this sensitivity analysis.

\subsection{SENSITIVITY ANALYSIS - TRANSPORTABLE STORAGE CASK}

Approximately 750 MTU of spent fuel is postulated in the MRS System study to be transported in transportable storage casks (TSCs) from reactors in the first year of the three-phased MRS deployment mode. Given the OFF shipment rule, some of these shipments originate at reactors that do not have the crane capacity and/or the rail access required to handle the 125-ton TSCs. Systems such as dry-transfer to TSCS, the use of heavy-haul truck to transport TSCS to the raithead have not been adequately defined as yet; neither has the disposition of TSCs, or their integration with the transport-only cask fleet been established. Therefore, TSCS were not included in the transportation analysis presented in earlier sections, and the implementation of TSCs in an MRS/no-MRS system is considered beyond the scope of this analysis. In addition, the relatively small percentage (1.2\%) that 750 MTU is of the total quantity $(63,000 \mathrm{MTU})$, indicates that TSCS would not be a significant discriminator in the comparison of alternative MRS functions and locations from a transportation cost and dose perspective.

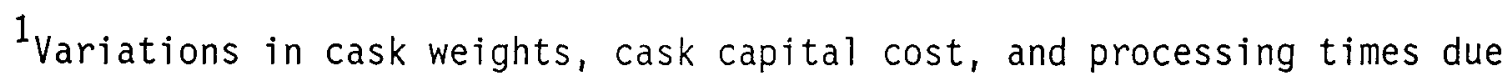
to cask capacity changes are assumed to change total cost by less than $10 \%$. 
Table 37. Summary of Transportation Costs and Doses for Reference, Lower, and Higher Cask Capacities

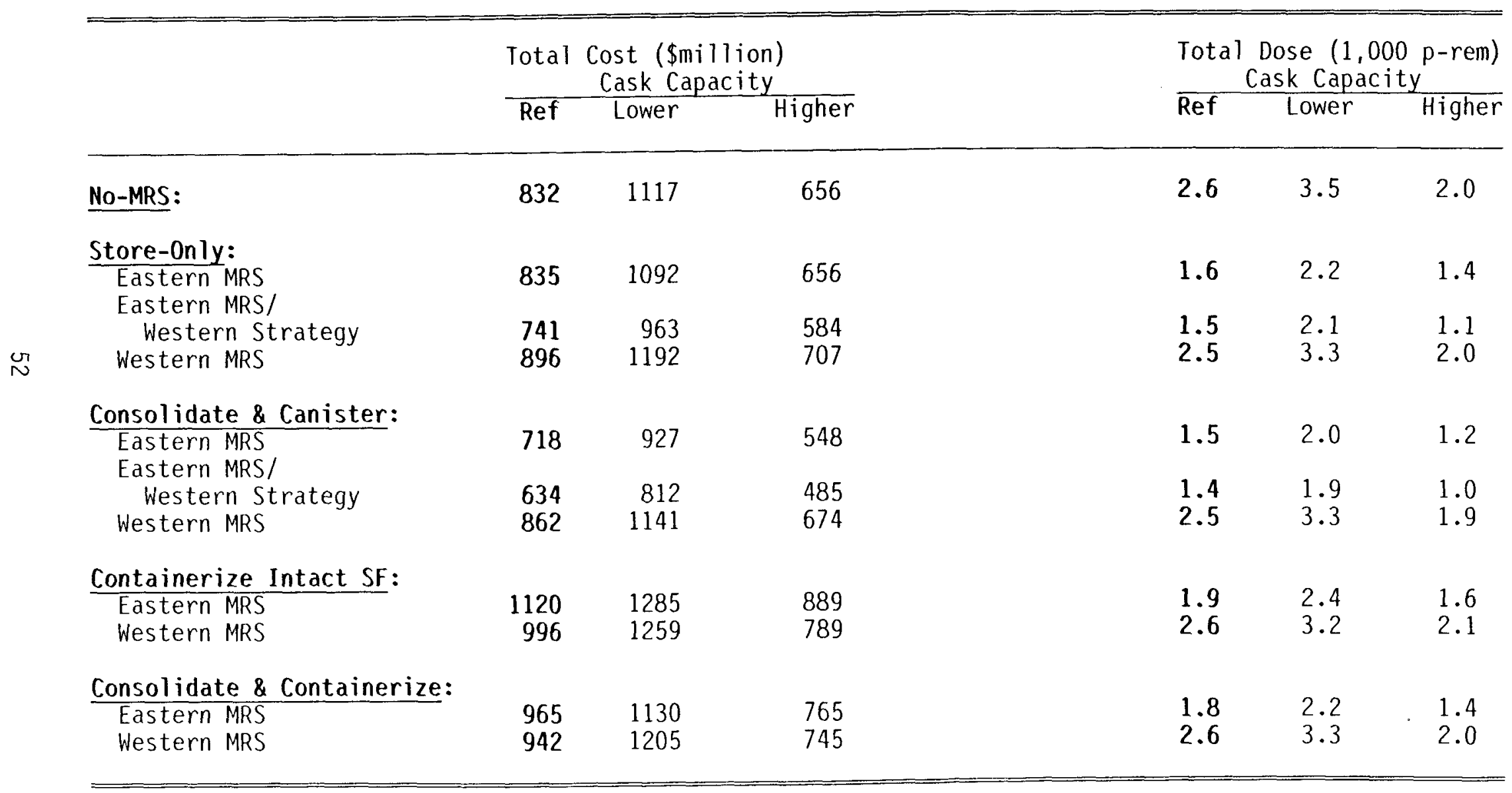


Table 38. Cost by Transportation Link (\$millions) -

Reactors to MRS/Repository

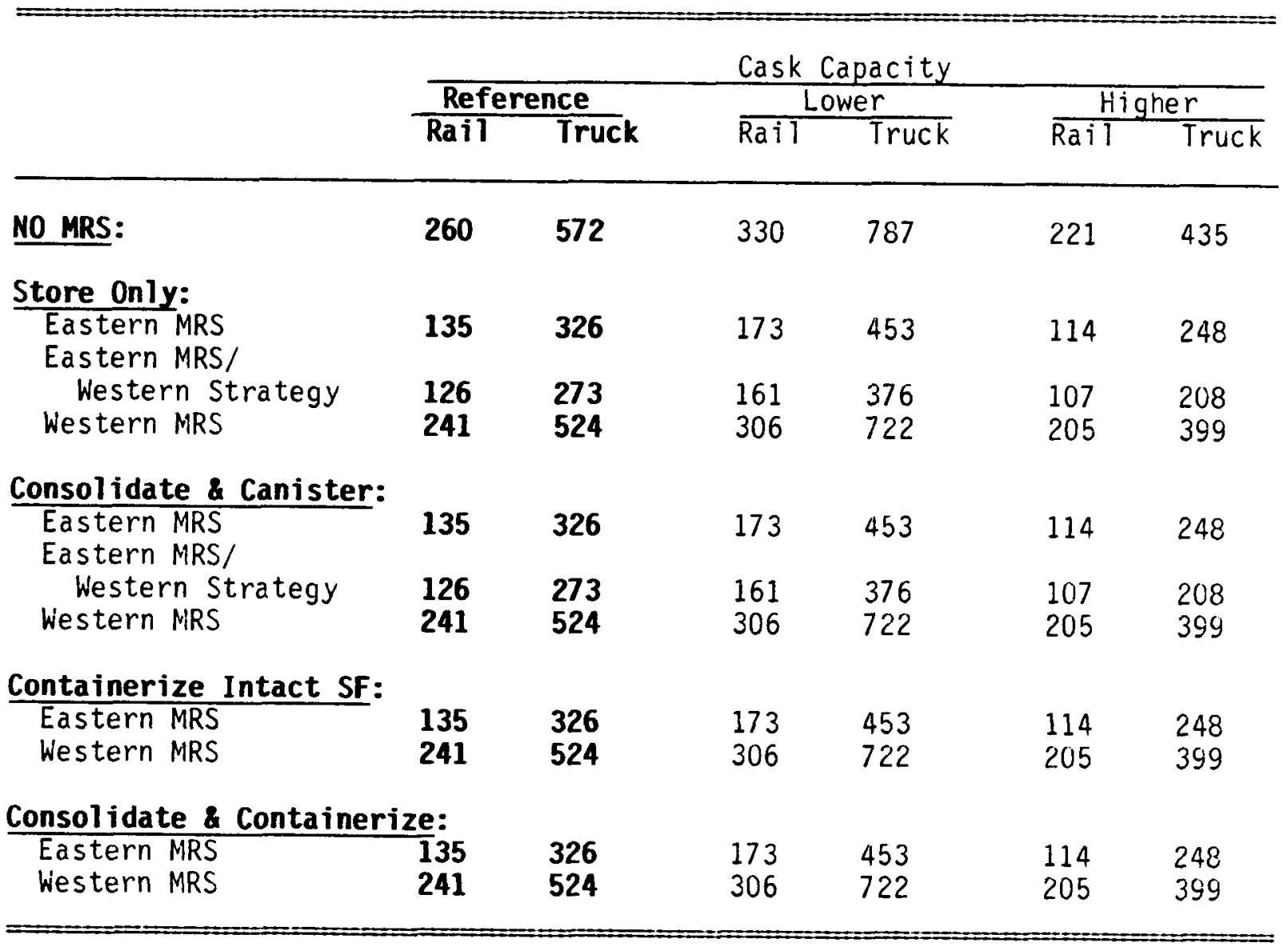


Table 39. Cost by Transportation Link (\$millions)

- MRS to Repository

\begin{tabular}{|c|c|c|c|}
\hline & \multicolumn{3}{|c|}{ Cask Capacity } \\
\hline & Reference & Lower & Higher \\
\hline No MRS: & -- & -- & $-\cdots$ \\
\hline \multicolumn{4}{|l|}{ Store Only: } \\
\hline $\begin{array}{l}\text { Eastern MRS } \\
\text { Eastern MRS/ }\end{array}$ & 374 & 466 & 294 \\
\hline $\begin{array}{l}\text { Eastern MRS/ } \\
\text { Western Strategy } \\
\text { Western MRS }\end{array}$ & $\begin{array}{l}342 \\
131\end{array}$ & $\begin{array}{l}426 \\
164\end{array}$ & $\begin{array}{l}269 \\
103\end{array}$ \\
\hline \multicolumn{4}{|l|}{ Consolidate \& Canister: } \\
\hline $\begin{array}{l}\text { Eastern MRS } \\
\text { Eastern MRS/ }\end{array}$ & 257 & 301 & 186 \\
\hline $\begin{array}{l}\text { Western Strategy } \\
\text { Western MRS }\end{array}$ & $\begin{array}{r}235 \\
96\end{array}$ & $\begin{array}{l}275 \\
113\end{array}$ & $\begin{array}{r}170 \\
70\end{array}$ \\
\hline \multicolumn{4}{|l|}{ Containerize Intact SF: } \\
\hline $\begin{array}{l}\text { Eastern MRS } \\
\text { Western MRS }\end{array}$ & $\begin{array}{l}659 \\
231\end{array}$ & $\begin{array}{l}659 \\
231\end{array}$ & $\begin{array}{l}527 \\
185\end{array}$ \\
\hline \multicolumn{4}{|c|}{ Consolidate \& Containerize: } \\
\hline $\begin{array}{l}\text { Eastern MRS } \\
\text { western MRS }\end{array}$ & $\begin{array}{l}504 \\
177\end{array}$ & $\begin{array}{l}504 \\
177\end{array}$ & $\begin{array}{l}403 \\
141\end{array}$ \\
\hline
\end{tabular}


Table 40. Risk by Transportation Link (1,000 person-rem)

- Reactors to MRS/Repository

\begin{tabular}{|c|c|c|c|c|c|c|}
\hline & \multicolumn{6}{|c|}{ Cask Capacity } \\
\hline & \multicolumn{2}{|c|}{ Reference } & \multicolumn{2}{|c|}{ Lower } & \multicolumn{2}{|c|}{ Higher } \\
\hline & Rail & Truck & $\overline{R a i l}$ & Truck & $\overline{R a i l}$ & Truck \\
\hline No MRS: & 0.7 & 1.9 & 0.9 & 2.6 & 0.6 & 1.4 \\
\hline \multicolumn{7}{|l|}{ Store only: } \\
\hline $\begin{array}{l}\text { Eastern MRS } \\
\text { Eastern MRS/ }\end{array}$ & 0.4 & 0.9 & 0.6 & 1.2 & 0.4 & 0.7 \\
\hline $\begin{array}{l}\text { Western Strategy } \\
\text { Western MRS }\end{array}$ & $\begin{array}{l}0.4 \\
0.7\end{array}$ & $\begin{array}{l}0.8 \\
1.7\end{array}$ & $\begin{array}{l}0.5 \\
0.9\end{array}$ & $\begin{array}{l}1.2 \\
2.3\end{array}$ & $\begin{array}{l}0.3 \\
0.6\end{array}$ & $\begin{array}{l}0.6 \\
1.3\end{array}$ \\
\hline \multicolumn{7}{|c|}{ Consolidate \& Canister: } \\
\hline $\begin{array}{l}\text { Eastern MRS } \\
\text { Eastern MRS/ }\end{array}$ & 0.4 & 0.9 & 0.6 & 1.2 & 0.4 & 0.7 \\
\hline $\begin{array}{l}\text { Western Strategy } \\
\text { Western MRS }\end{array}$ & $\begin{array}{l}0.4 \\
0.7\end{array}$ & $\begin{array}{l}0.8 \\
1.7\end{array}$ & $\begin{array}{l}0.5 \\
0.9\end{array}$ & $\begin{array}{l}1.2 \\
2.3\end{array}$ & $\begin{array}{l}0.3 \\
0.6\end{array}$ & $\begin{array}{l}0.6 \\
1.3\end{array}$ \\
\hline \multicolumn{7}{|c|}{ Containerize Intact SF: } \\
\hline $\begin{array}{l}\text { Eastern MRS } \\
\text { Western MRS }\end{array}$ & $\begin{array}{l}0.4 \\
0.7\end{array}$ & $\begin{array}{l}0.9 \\
1.7\end{array}$ & $\begin{array}{l}0.6 \\
0.7\end{array}$ & $\begin{array}{l}1.2 \\
2.3\end{array}$ & $\begin{array}{l}0.4 \\
0.6\end{array}$ & $\begin{array}{l}0.7 \\
1.3\end{array}$ \\
\hline \multicolumn{7}{|c|}{ Consolidate \& Containerize: } \\
\hline $\begin{array}{l}\text { Eastern MRS } \\
\text { Western MRS }\end{array}$ & $\begin{array}{l}0.4 \\
0.7\end{array}$ & $\begin{array}{l}0.9 \\
1.7\end{array}$ & $\begin{array}{l}0.6 \\
0.9\end{array}$ & $\begin{array}{l}1.2 \\
2.3\end{array}$ & $\begin{array}{l}0.4 \\
0.6\end{array}$ & $\begin{array}{l}0.7 \\
1.3\end{array}$ \\
\hline
\end{tabular}


Table 41. Risk by Transportation Link (1,000 person-rem) MRS to Repository

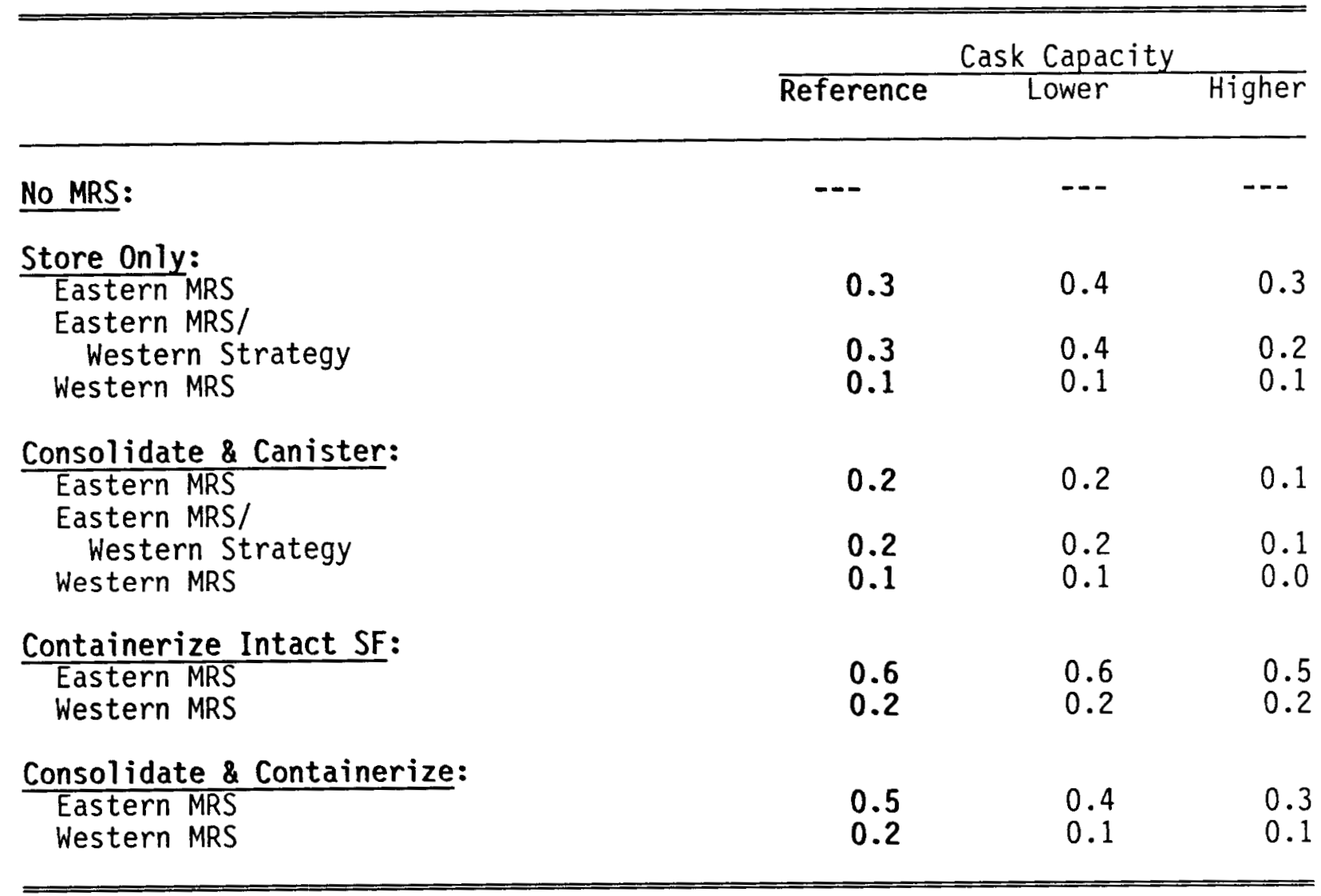




\subsection{CONCLUSIONS}

The principal conclusions of this study are listed below. These conclusions are based on the analyses presented in chapters 4 and 5 .

\subsection{TRANSPORTATION COSTS}

In general, from a transportation standpoint, the MRS is economically more favorable than a no-MRS system when its packaging function maximizes MRS-torepository cask capacity and minimizes reactor-to-MRS shipment-miles. When evaluating the generic Eastern and Western MRS locations, only the generic Eastern MRS that stores and ships intact fuel with a Western strategy or consolidates and canisters fuel realizes these above efficiencies to the extent that they provide a net transportation cost savings over a no-MRS system. Savings range from \$100-200 million over the 24-year life of the project. Note the sensitivity cases assessing six regional centroid results in figures consistent with the generic MRS analysis (see Table 23 in Chapter 5).

In the store-only case with the generic Eastern MRS, Western strategy would be needed to minimize cross-country shipping to bring system transportation costs closer to the no-MRS system. For the consolidate-and-containerize and containerize-intact cases, the from-MRS cask efficiency is low, so an Eastern MRS location causes increased costs. The Western MRS does not significantly reduce cross-country shipping miles, so none of the Western MRS cases gives lower costs than the no-MRS case.

A comparison between the generic Eastern MRS and the generic Western MRS indicates that the generic Eastern MRS provides the following (from Table 12 in Chapter 4). The cost variation depends on whether or not the western strategy is used.

- 5 to $15 \%$ cost savings for the store-only case because an MRS location in the East maximizes cross-country spent fuel shipment in from-MRS casks and carrying intact fuel allows good packing efficiency in the from-MRS cask.

- 15 to $25 \%$ cost savings for the consolidate and canister case because an MRS location in the east maximizes crosscountry spent fuel shipment in from-MRS casks and carrying canisters with consolidated fuel allows very good packing efficiency in the from-MRS cask.

- 2 to $10 \%$ increase for the containerized intact spent fuel case because an MRS location in the East maximizes crosscountry spent fuel shipments in from-MRS casks and carrying repository containers, either with or without consolidated fuel, results in low packing efficiency.

The minimum shipment-mile MRS location, described in Section 5.2, when compared to the generic Eastern MRS location indicates:

- 15 to $25 \%$ cost savings for the store-only case 
- 25 to $35 \%$ cost savings for the consolidate-and-canister case

- 1 to $10 \%$ cost savings for the consolidate-and-containerize case.

The minimum shipment-mile MRS location moves the MRS to give a reduced average distance from the reactors in comparison to the generic Eastern MRS location. Because the minimum shipment-mile MRS location is west of the generic MRS location, the MRS to repository distance also decreases. The reduced distance gives a cost decrease of more than $10 \%$ for the minimum shipment-mile MRS location, compared to the generic MRS location. This shifts all costs for the minimum shipment-mile MRS location about $10 \%$ lower, so there is an improvement of $10 \%$ in the comparison of the minimum shipment-mile MRS location with the generic Eastern MRS.

In terms of packaging function, an MRS that consolidates and canisters spent fuel appears superior in terms of reducing transportation cost than the three other alternatives analyzed in this study because consolidation of fuel into canisters allows efficient use of the cask interior space. It is worth noting that the cost differential among packaging functions is somewhat sensitive to MRS location because the location affects shipping distance and, thus, the degree of utilization of a particular efficient (or inefficient) cask type. Specifically, for the generic Eastern MRS the choice of packaging function can lead to cost savings of up to $\$ 490$ million compared to $\$ 135$ million for the generic Western MRS because the Western MRS is closer to the repository, giving a shorter shipping distance than the Eastern MRS. The shorter shipping distance makes the Western MRS less sensitive to changes in packaging function and the resulting variation in cask loading efficiency. In addition, for the minimum shipment-mile MRS location, the choice of packaging function can lead to a cost savings of up to $\$ 430$ milition. Because the minimum shipment-mile MRS location is closer to the repository than the generic Eastern MRS, the packaging function has slightly less effect on cost.

For a given packaging function, the choice between the generic Eastern and generic Western MRS locations can impact transportation cost by as little as $\$ 20 \mathrm{milli}$ ion and up to $\$ 150 \mathrm{million}$. Similarly, for a given packaging function, the choice between the minimum shipment-mile MRS and the generic Western MRS location can impact tranportation cost by as little as $\$ 1$ million and up to $\$ 230$ million. The large transportation cost difference ( $\$ 150$ million for the generic or $\$ 230$ million for the minimum shipment-mile location) occurs for the consolidate-and-canister case where the Eastern MRS locations gain a major advantage over the Western MRS locations, due to the high capacity of the MRS cask. With a Western MRS location, shipments from reactors travel across the U.S. in the lower capacity truck or rail casks, and are then placed into the higher-capacity MRS cask. The minimum shipment-mile MRS location is further enhanced because the shipping distance from the reactors to the MRS is less in the minimum shipment-mile MRS case than with the generic Eastern location. For the packaging functions that result in transporting repository containers (i.e., containerization cases), the MRS cask efficiency drops and the Western MRS is, thus, more favorable than the Eastern MRS.

With a generic Eastern MRS location, a Western strategy reduces transportation cost by about $\$ 95$ million for an MRS that stores only and about $\$ 85 \mathrm{mil}-$ iion for an MRS that consolidates and canisters. This is due to the reduction 
in total shipment-miles resulting from not shipping from the Western reactors to an Eastern MRS and then back to the Western repository.

In addition to lower transportation costs, an Eastern MRS system results in a reduced number of shipments and shipment-miles when compared to a Western MRS or a no-MRS system. Table 14 in Chapter 4 contains information on the cask days in transit, shipment-days in transit, and an estimate of the average number of shipments per day for both generic Eastern and Western MRS locations and the no-MRS system. As expected, the average number of shipments in transit per day for an Eastern MRS system is approximately half of the corresponding number of shipments in transit for the no-MRS or Western MRS system. A similar pattern can be seen for shipment-days in transit and cask-days in transit. This reflects the elimination of truck and 100-ton rail cask shipments from reactors across the country to the repository or Western MRS.

The use of overweight truck casks (5 PWR/12 BWR assemblies) can reduce the cost of from-reactor shipments by approximately $\$ 80$ to $\$ 160$ million when compared to legal-weight truck casks (3 PWR/7 BWR assemblies), depending on the FWMS configuration and MRS location due to the increased capacity and, therefore, fewer shipments.

Variations in cask capacities do not appear to affect the relative comparisons of MRS packaging and location options.

The option of shipping HLW directly to the repository is noticeably more cost-effective than shipping through an Eastern MRS, and marginally more costeffective than shipping through a Western MRS. As shown in Table 22 in Chapter 4, the total shipping distance for ICPP and Hanford increases significantly for the Eastern MRS compared to the no-MRS case. These two sites ship about $45 \%$ of the HLW. The Western MRS al so results in an increase in shipping distance. The increased shipping distances translate into higher transportation costs.

\subsection{TRANSPORTATION DOSE}

The total transportation dose for the 11 core cases indicates that the transport of spent fuel results in an in-transit dose varying from 1,400 person-rem for spent fuel consolidation and canistering at an Eastern MRS with a Western strategy to 2,600 person-rem for a no-MRS system. An Eastern MRS provides a dose reduction of from 25 to $45 \%$ over a western MRS (depending on the selection of packaging function) or a no-MRS system, because of the reduced number of cross-country shipments.

For perspective, the average annual dose from natural background radiation has been estimated to be about 0.1 person-rem. Using the conversion given in the 1986 Repository Environmental Assessment for Yucca Mountain, Nevada (Ref. 9) that 1 person-rem equals 0.0002 latent-cancer fatality (LCF), then roughly 5,000 LCFs result annually in the United States from background radiation. The radiation exposures from transporting spent fuel directly to the repository would result in about 0.02 additional LCF per year over the 24-year transportation program involving the first repository. An Eastern MRS with the Western spent fuel strategy results in a reduction in total dose by nearly half of the dose for the no-MRS case or the generic Western MRS cases. This is because the number of cross-country shipments is reduced. 


\subsection{TRANSPORTATION NONRADIOLOGICAL RISK}

Nonradiological risk was not calculated in this study. However, estimates for similar high-level waste shipping activities indicate that nonradiological risk is much higher than the radiological risk (DOE, 1986). Some results of the Monitored Retrievable Storage Submission to Congress are summarized as follows. Nonradiological risk for transportation of spent fuel from reactors and then to a repository at Yucca Mountain was reported as 12 fatalities and 140 injuries with $30 \%$ of from-reactor shipments transported by truck and $70 \%$ by rail, and all from-MRS shipments in 150-ton casks. Application of a Western strategy reduces shipment-miles and was reported to reduce fatalities to 10 and injuries to 120 . 


\subsection{REFERENCES}

(1) U.S. Department of Energy (DOE/HQ), 1988. "Action Plan for Systems Study to Support the MRS Commission," memo from Ralph Stein, Acting Associate Director, Office of Systems Integration and Regulations, OCRWM, and Stephen H. Kale, Acting Associate Director, Office of Facilities Siting and Development, OCRWM, Washington, DC. May 31.

(2) Office of Civilian Radioactive Waste Management, 1988. "MRS Systems Study, Task A, Scenario Development and System Logistics," memo from Ralph Stein, Acting Associate Director, Office of Systems Integration and Regulations, Appendix A in MRS System Study Summary Report (Task J), U.S. Department of Energy, Washington, DC, May, 1989, in publication.

(3) Gupta, S., S. Tzemos, and C. Boggs-Mayes, 1988. "TRICAM: Transportation Risk and Cost Analysis Model for the Office of Civilian Radioactive Waste Management," Proceedings of the Symposium on Waste Management, Tucson, AZ, March 1988.

(4) Joy, D. S., P. E. Johnson, and S. M. Gibson, 1982. HIGHWAY, A Transportation Routing Model: Program Description and User's Manual, ORNL/TM-8149, Oak Ridge National Laboratory, Oak Ridge, TN.

(5) Peterson, B.E., 1983. INTERLINE, A Rail road Routing Model: Program Description and User's Manual, ORNL/TM-8944, Oak Ridge National Laboratory, Oak Ridge, TN.

(6) U.S. Department of Energy, 1987. Additional Information on Monitored Retrievable Storage, DOE/RW-0166, Office of Civilian Radioactive Waste Management, Washington, DC.

(7) U.S. Department of Energy, 1986. Monitored Retrievable Storage Program Plan, Vol. II, D0E/RW-0035/1, Report to Congress, Office of Civilian Radioactive Waste Management, Washington, DC.

(8) Energy Information Administration, 1987. Commercial Nuclear Power 1987 Prospects for the United States and the World, DOE/EIA-0438(87).

(9) U.S. Department of Energy, 1986. Environmental Assessment, Yucca Mountain Site, Nevada Research and Development Area, Nevada, Nuclear Waste Policy Act (Section 112), DOE/RW-0073, Office of Civilian Radioactive Waste Management, Washington, $D C$.

(10) Walling, R. C., C. M. Heeb, and W. L. Purcel1, 1988. Reactor-Specific Spent Fuel Discharge Projections: 1987-2020, PNL-6430, Pacific Northwest Laboratory, Richland, WA. 
APPENDIX A

COST ALGORITHMS 
APPENDIX A

COST ALGORITHMS

This appendix contains a listing of the cost algorithms used to calculate transportation costs for spent nuclear fuel and high-level waste.

\section{A.1 ANNUAL SHIPPING COSTS}

The annual shipping costs for each reactor consist of the annual transportation cost and the cask costs. The annual transportation cost is calculated from the annual number of shipments and the route cost per shipment. The cask costs depend on the number of cask trips per year and the cask use, maintenance, and handling costs.

\section{A.1.1 Annual Number of Cask Trips}

The annual number of cask trips per reactor is calculated from the MTU scheduled for shipment from each reactor each year, the cask capacity in assemblies, and the MTU per assembly. For each year and for each reactor, the equations used are:

$$
\text { Number of Assemblies = MTU (year, rx }) / \text { MTU per Assembly }
$$

The "rx" and "year" are the year and reactor indexes, respectively.

$$
\begin{aligned}
\text { Annual Number of Cask Trips }= & \text { Number of Assemblies / } \\
& \text { Cask Cap (mode, rxtype) }
\end{aligned}
$$

Cask Cap is the cask capacity in assemblies for each transportation mode (mode) and reactor type (rxtype).

\section{A.1.2 Annual Number of Shipments}

The annual number of shipments per reactor is

Annual Number of Shipments = Annual Number of Cask Trips / Casks per Shipment (mode, rx)

\section{A.1.3 Annual Transportation Cost}

The annual transportation cost for each reactor is

$$
\text { Transp } \operatorname{cost}(\text { year, rx })=\begin{aligned}
& \text { Annual Number of Shipments * } \\
& \text { Route Cost (mode, rx) }
\end{aligned}
$$

where Route cost is the round trip hauling cost for each route (reactor to repository) and for each transportation mode (truck or rail). This cost includes shipping security, demurrage, and second driver charges, but excludes cask-related charges, i.e., cask capital cost, maintenance, and handling. 


\section{A.1.3.1 Rail Route Costs}

The rail route costs consist of hauling, security, and inspection costs, given by

$$
\text { Route Cost }(r a i 1, r x)=\underset{\text { Inspection Cost }}{\text { Hauling Cost }(r a i l, r x)+\text { Security Cost }(r a i 1, r x)+}
$$

The hauling costs are

$$
\begin{aligned}
\text { Hauling Cost }= & {\left[(9 / 40) * 0.1616^{\star D} \text { Distance** }(0.586)\right] *(W F+\text { WE }) * } \\
& \text { Casks per Shipment }+ \text { RSopt*96*Distance }
\end{aligned}
$$

Distance is the route distance (in miles).

WF, WE are the cask weights loaded and empty, respectively [in hundredweight $(\mathrm{cw})$ ]

Casks per Shipment is an input specified for each transportation mode.

RSopt is the user-defined service option:

RSopt $=0$ indicates regular services

RSOpt $=1$ indicates round-trip dedicated train

RSopt $=0.5$ indicates one-way dedicated train.

Spent fuel is assumed to be transported from reactors via one-way dedicated trains with a consist of 3 casks.

It has been assumed that an average amount of fuel removed from-reactor in an annual refueling is about $30 \mathrm{MTU}$, which represents about 3 rail caskloads.

Reactors typically discharge about 30 MTU of spent fuel annually. At steady state the oldest fuel first (OFF) pickup scenario implies picking up one years spent fuel from each reactor each year, e.g., some 100 reactors producing about 30 MTU per year gives the expected 3,000 MTU per year of spent fuel shipped to the MRS/repository. An examination of the OFF schedule used to specify the annual shipments for the TRICAM from reactor calculations shows most reactors shipping about 15 to 40 MTU per year with the exceptions of a few anomalies caused by reactor startups or shutdowns.

A typical rail shipping campaign at a reactor would be expected to pick up the annual OFF allotment each year, that is, about 30 MTU of spent fuel. Because a rail cask carries about 9.5 MTU, this gives a campaign size of 3.1 (30 divided by 9.5). Due to the large fixed overhead involved in loading a cask, it would be very unlikely that a cask would be partially filled, so 3.1 is rounded to 3 . The actual campaign size will vary depending on the amount of fuel shipped from a reactor in a particular year and the availability of crews to carry out loading at the reactor sizes. The actual consist size may vary from shipment to shipment, and the question of optimum consist size will require a study of the trade-offs involved in the economics of rail shipments, requirements of OFF scheduling, and the loading capabilities at reactors. The campaign size of three casks selected for this study is not an optimized value

$1 X * * Y$ means raise $X$ to the $Y$ power. 
but is consistent with typical annual shipment sizes for the OFF schedule, would not overcommit personnel resources at reactors, and is sufficiently accurate for the scoping of transportation costs.

For from-MRS rail shipment, a 5-cask round-trip dedicated train is used. Selection of shipping campaign size must also reflect the effect of the need to efficiently unload the group of casks when they arrive at the receiving facility (MRS or repository). Due to the high dedicated rail charge, the rail transportation cost is generally decreased by increasing the campaign size. However, the receiving facility capital cost is generally decreased by steady arrivals. In order to turn around a large group of casks arriving at one time in an expeditious fashion, more parallel unloading bays are needed than steadystate operation would require. Thus, a large shipping campaign size will increase receiving facility costs. If large shipping groups arrive at a facility designed for steady-state receiving, the cask turnaround time increases. Increased turnaround time will cause fleet size to increase, resulting in higher transportation costs. In either case, the interface between the nuclear waste transportation system and the receiving system favors near steady-state operation, i.e., small shipping groups.

The rail campaign size for from-reactor shipments is more constrained by the single loading bay at reactor, reactor crew capabilities, and the quantity of fuel shipped annually. In from-MRS to repository shipments, the fromreactor shipping constraints do not apply. However, cask loading/unloading facility capital requirements still push in the direction of small shipping campaigns. A selection of 5 casks in the MRS to repository loop was not the result of a detailed optimization study of transportation/facility interfaces, but does reflect consideration of typical repository receiving system and transportation system operating characteristics to select a reasonable shipping campaign size.

The security costs are calculated by

$$
\text { Security Cost }(\text { rail, } r x)=\underset{500 \star \text { Loading Time at } r x}{0.76^{\star} \text { Distance }+500 * \text { Trip Time }+}
$$

The Loading Time at $r x$ (in days) is the loading time at reactors for each cask type. Trip Time is defined by Equation 14.

The inspection cost is

$$
\text { Inspection Cost }=470 * \text { Loading Time at } r \times * \text { Casks per Shipment }
$$

where the loading time is in days.

\section{A.1.3.2 Truck Route Costs}

The route costs for truck transport are

$$
\begin{aligned}
\text { Route Cost }(\text { truck, } r x)= & \text { Hauling Cost }+ \text { Second Driver Charge }+ \\
& \text { Demurrage Charge at } r x+ \\
& \text { Inspection Cost }+ \text { Security Cost }(\text { truck, rx }) .
\end{aligned}
$$


The hauling costs are given by

$$
\begin{aligned}
\text { Hauling Cost }= & {\left[\left(1.1614+0.004764^{*} \text { Distance }\right) * W F+\right.} \\
& \left.\left(0.3954+0.00402^{*} \text { Distance }\right) * W E\right] * \\
& \text { Casks per Shipment }
\end{aligned}
$$

The second driver cost is

$$
\text { Second Driver Cost }=0.5^{\star} \text { Distance }{ }^{\star} \text { Casks per Shipment }
$$

Demurrage charges at the reactors are based on the cask loading and unloading times and the following sliding scale:

Load Time (Hours)

$$
\begin{aligned}
& 0-3 \\
& 3-24 \\
& >
\end{aligned}
$$

\section{Charge}

0

$\$ 20 /$ cask/hr for each hour over 3 hours $\$ 420+\$ 25 /$ cask/hour for each hour over 24 hours

Inspection and security costs are calculated by

Inspection Cost $=470^{*}$ Loading Time at $r \times *$ Casks per Shipment

Security Cost (truck, $r x)=1.47 *$ Distance ${ }^{*}$ Casks per Shipment + $2 *$ Truck Security Cost $(r x)$

The Truck Security Cost is calculated by assuming a $\$ 1.50 / \mathrm{mile}$ for each security escort through the urban areas and $\$ 200 /$ engagement. The number of engagements is optimized.

\section{A.1.3.3 Travel Time Calculation}

Travel time is estimated in days using the following equations:

$$
\text { Trip Time }=(\text { Travel Time }+ \text { Time Stopped }) / 24
$$

$$
\text { Travel Time }=\text { Distance } *(1 / \text { Speed Loaded }+1 / \text { Speed Empty })
$$

$$
\text { Time Stopped }=\text { Stopped Loaded + Stopped Empty }
$$

The stopped times are specified by the user in hours/mile; the code multiplies the hours/mile and the Distance to obtain the stopped time. The loaded and empty speed are calculated using equation

$$
\begin{aligned}
& \text { Speed Loaded }=\text { Coef*Distance }{ }^{\star \star} \text { Exp } \\
& \text { Speed Empty }=\text { Coef*Distance }{ }^{\star \star} \text { Exp }
\end{aligned}
$$

The empty and loaded coefficients and exponents are user-specified for truck and rail. 


\section{A.1.4 Annual Cask Use Costs}

The annual cask use costs consist of the capital charges, the cask maintenance charges, and the cask handling charges at the reactors and repository.

The annual capital charges for the casks used by each reactor are:

$$
\begin{aligned}
\text { Cask Capital Charge (year, } r x)= & \text { Cask Days * } \\
& \text { Cask Use Fee per Day (mode) }
\end{aligned}
$$

The transportation mode is determined by the rail availability at each reactor. If the reactor is accessible by rail, the mode is rail; otherwise, the mode is truck.

The cask days are

$$
\begin{aligned}
\text { Cask Days }= & \text { Annual Number of Cask Trips * (Travel Time }+(\mathrm{N}+1) / 2 * \\
& \text { Cask Turnaround Time at Reactor + Cask Turnaround } \\
& \text { Time at Storage Facility) }
\end{aligned}
$$

where $\mathrm{N}$ is the number of casks per shipment.

The daily cask use fee is

$$
\text { Cask Use Fee per Day (mode) }=\begin{aligned}
& \text { CRF } * \text { Cask Cost (mode) } / \\
& \text { Cask Utilization (mode) }
\end{aligned}
$$

where Cask cost is in dollars and Cask Utilization is the number of days per year a cask is used. The capital recovery factor (CRF) is

$$
\begin{aligned}
\mathrm{CRF}= & {[\mathrm{ROR} *(1+\mathrm{ROR}) * * \text { Cask Life(mode) }] / } \\
& {[(1+\mathrm{ROR}) * * \text { Cask Life (mode) })-1] }
\end{aligned}
$$

where ROR is the rate of return in percent on the cask investment.

If $R O R=0.0$, then

$$
\text { CRF }=1.0 / \text { Cask Life (mode) }
$$

The annual cask maintenance charges are:

$$
\begin{aligned}
\text { Cask Maintenance Charge }(\text { year, } r x)= & \text { Cask Days * } \\
& \text { Cask Maint Fee per Day (mode) } \\
\text { Cask Maint Fee per Day (mode) }= & \text { Cask Maintenance Cost(mode) } \\
& / \text { Cask Utilization(mode) }
\end{aligned}
$$

The Cask Maintenance Cost is specified in dollars as an input.

\section{A.2 ACCUMULATED ANNUAL COSTS}

The annual costs are accumulated for all reactors and for all years that spent fuel shipments are specified. The results are total costs by transportation mode--truck and rail--and their sum. 
The accumulated cost parameters are:

- Hauling cost,

- Security cost,

- Cask capital charges, and

- Cask maintenance charges.

The sum of all of these cost parameters is the total transportation cost. 
APPENDIX B

GENERIC MRS ROUTE AVERAGING METHOD 


\section{APPENDIX B}

\section{GENERIC MRS ROUTE AVERAGING METHOD}

In TRICAM, every route (i.e., from every origin to every destination) is presented as a series of links. There is one link for every State road type and population density zone traversed by that route. Mileage data are presented for each link. Figure B-1 shows an example of the links of a route traversing one State boundary. If the State were the only route attribute, then the link designation would change each time a State boundary is crossed. The route from $R$ to $A$ consists of:

Link $A_{1}$ through State 1 for

Link $A_{2}$ through State 2 for

Total through States 1 and 2
7 miles

$\underline{5 \text { miles }}$

12 miles

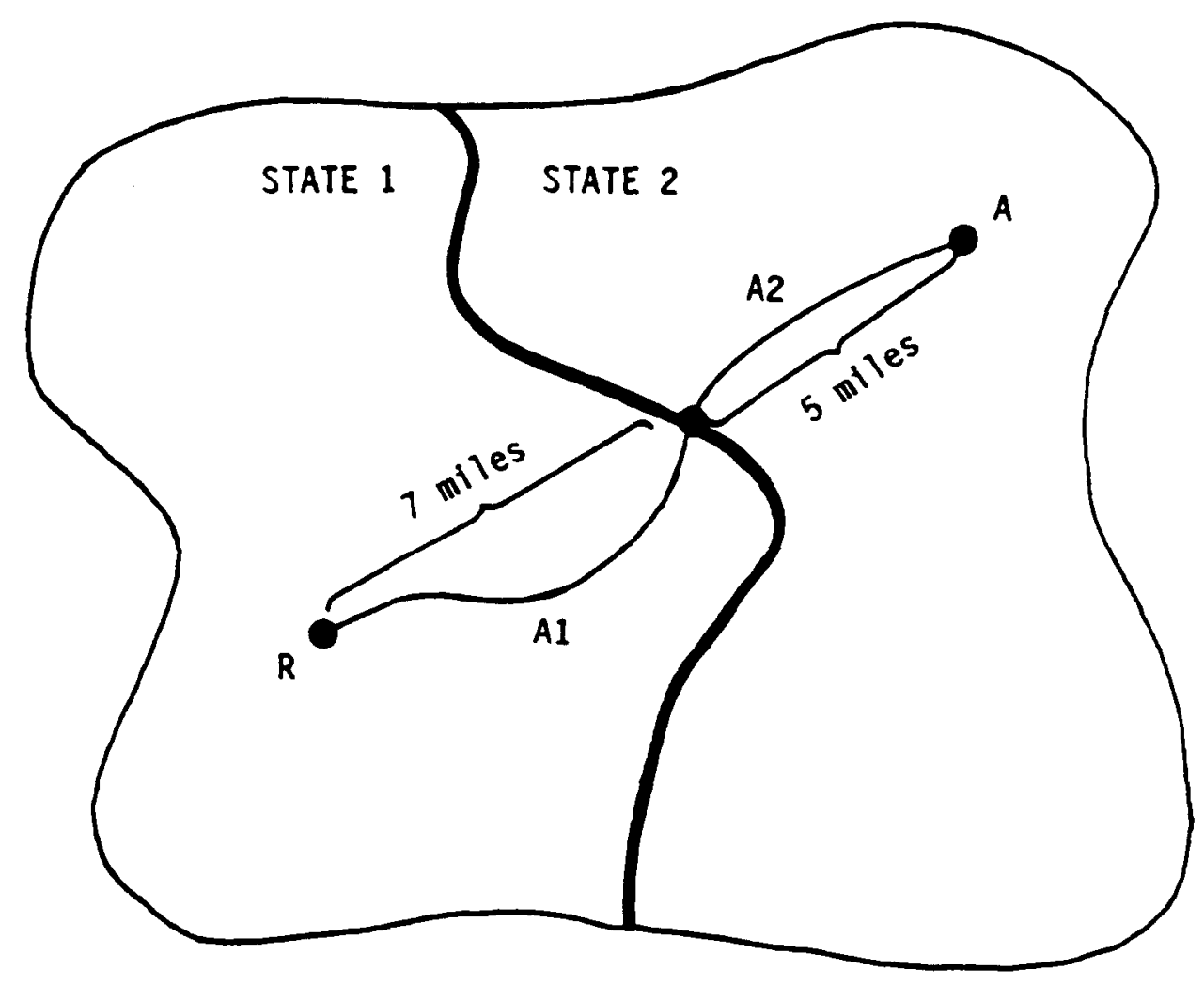

Figure B-1. Example of the TRICAM Route Links for a Route Transversing One State Boundary 
Figure B-2 shows the same route in a more detailed link representation. This time the link designation changes each time a State boundary or a population zone boundary is traversed. Thus route RA consists of the following links:

\begin{tabular}{|c|c|c|c|}
\hline Link & State & Population Zone & Miles \\
\hline$A_{19}$ & 1 & $\mathrm{Pg}$ & 4.5 \\
\hline$A_{16}$ & 1 & $P_{6}$ & 2.5 \\
\hline$A_{26}$ & 2 & $P_{6}$ & 3.0 \\
\hline$A_{23}$ & 2 & $P_{3}$ & 2.0 \\
\hline Total & 1 and 2 & $P_{9}, P_{6}, P_{3}$ & 12.0 \\
\hline
\end{tabular}

Note that the first subscript in $A_{13}$ refers to the State and the second subscript to the population zone. Also note that the total route mileage is the same (12) in both ink representation schemes.

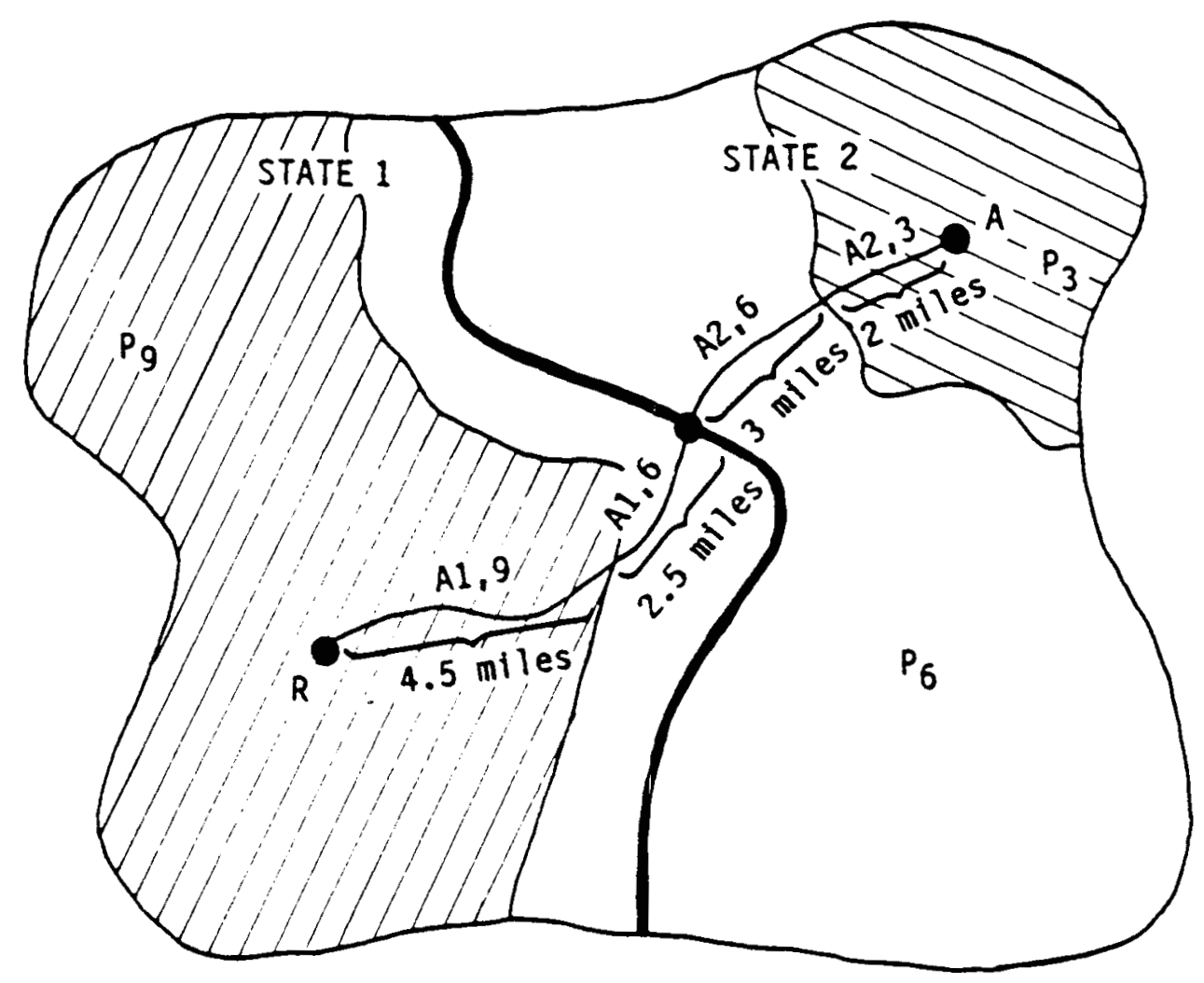

Figure B-2. Example of the TRICAM Route Links for a Route Transversing One State Boundary and Three Population Zones 
TRICAM uses a third index to designate road type and an identifier of urban/rural links. For simplicity this discussion will be continued with only the State and population zone indexes.

The link-by-link route data of the two Eastern (Western) MRS centroids are used to simulate the attributes of the average route for the corresponding generic Eastern (Western) MRS. The averaging process is presented through the examples depicted in Figures $B-3$ and $B-4$. Figure $B-3$ shows one reactor origin, at $R$, and two MRS centroids at $A$ and $B$. The routes are characterized by links.
A1 through State 1
7 miles
A2 through State 2
5 miles
B1 through State 1
8 miles
B2 through State 2
6 miles

The generic MRS falls somewhere between the two MRS locations A and $B$. Let $G_{1}$ and $G_{2}$ represent the generic MRS route links through State 1 and State 2, respectively. The mileage of link $G_{1}$ through State 1 is the sum of one half of the mileage for $A_{1}$ and one half of the mileage of $B_{1}$, as

$$
\text { Miles of } G_{1}=\frac{1}{2} \text { miles of } A_{1}+\frac{1}{2} \text { miles of } B_{1}
$$

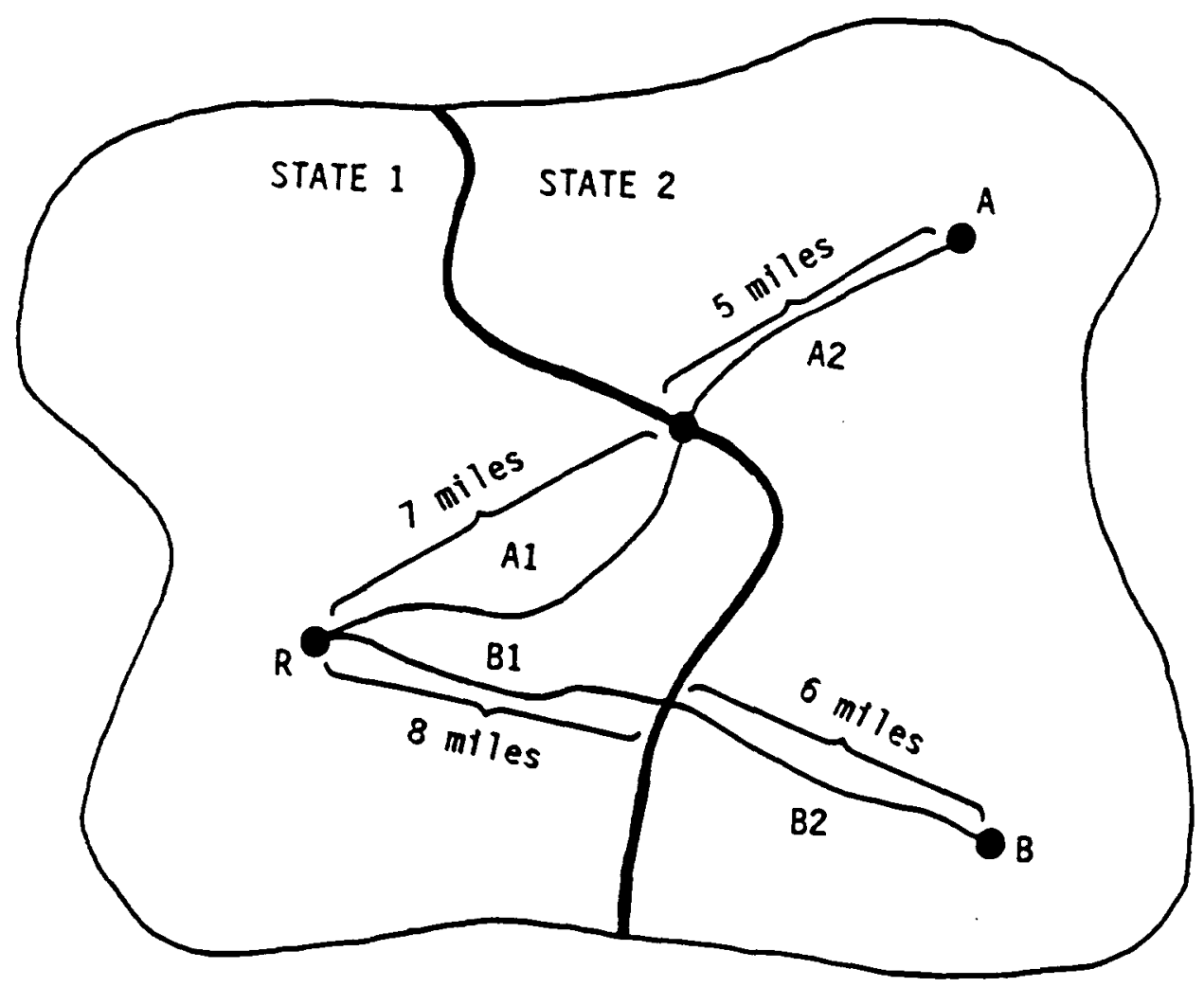

Figure B-3. Example of the TRICAM Route Links for Two Routes Transversing One State Boundary 
Similarly for link $G_{2}$ for State 2. So the generic route consists of links

$G_{1}$ through State 1 for $\frac{7+8}{2}=7.5$ miles

Total $\frac{G_{2}}{\left(G_{1}+G_{2}\right)}$ through State 1 and 2 for $\frac{5+6}{2}=\frac{5.5}{13}$ miles

Note that the total length of the generic route is the average of the lengths of the two centroid routes.

Total miles of route A 12

Total miles of route $B \quad 14$

Total miles of generic route $\overline{13}$.

Figure B-4 expands the example of Figure B-3 by considering links that traverse three population zones and one State boundary.

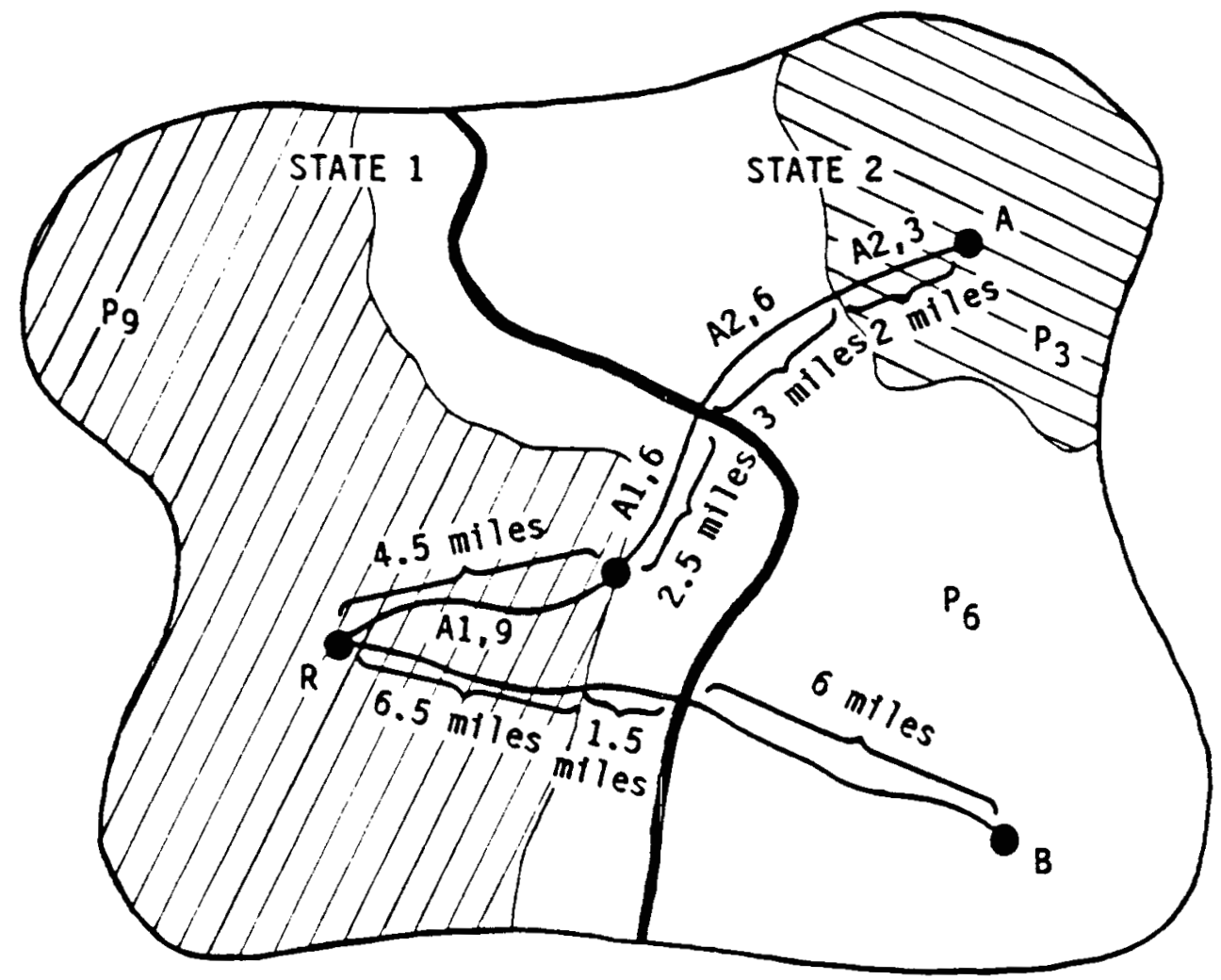

Figure B-4. Example of the TRICAM Route Links for Two Routes Transversing One State Boundary and Three Population Zones 
If the generic link for State 1 and population zone $P g$ is designated as $G_{19}$, the mileage of $G_{19}$ is the average of the mileages of $A_{19}$ and $B_{19}$, e.g.,

$$
\text { Miles of } \begin{aligned}
G_{19}=\frac{1}{2} \text { miles of } A_{19}+\frac{1}{2} \text { miles of } B_{19} \\
=\frac{1}{2} \cdot 4.5+\frac{1}{2} 6.5=5.5
\end{aligned}
$$

Similarly the mileage for $G_{16}, G_{26}$, and $G_{23}$ is

$$
\begin{aligned}
& \text { Miles of } G_{16}=\frac{1}{2} \cdot 2.5+\frac{1}{2} \cdot 1.5=2 \\
& \text { Miles of } G_{26}=\frac{1}{2} \cdot 3+\frac{1}{2} \cdot 6=4.5 \\
& \text { Miles of } G_{23}=\frac{1}{2} \cdot 2+\frac{1}{2} \cdot 0=1 \\
& \text { Total miles of all iinks }=13 \\
& \text { Note again that the total miles of all links is the average of the distances } \\
& \text { from } R \text { to the two MRS centroids } A \text { and } B \text {. }
\end{aligned}
$$




\section{APPENDIX C}

TRICAM: THE TRANSPORTATION RISK AND COST ANALYSIS MODEL

FOR THE CIVILIAN RADIOACTIVE WASTE MANAGEMENT PROGRAM 
TRICAM: THE TRANSPORTATION RISK AND COST ANALYSIS MODE

FOR THE CIVILIAN RADIOACTIVE MASTE MAHAGBUENT PROGRAM

\author{
Shashikant Qupta \\ Spyridon Tzonos \\ Office of Transportation Systess \& Planning \\ BATTELE, Projoct Managenent Division \\ Coluabus, Ohio 13281 \\ Cynthia Boggs-Mayes \\ U.S. Department of Energy, Chicago Operations Office \\ Argonne, Illinois 80439
}

ABSTRACT

This is the second paper on the subject of the application of optinization techniques to decision making in the Transportation Prograe of the Office of Civilian Radioactive Maste Manageaent (OCRWM). The first paper (1) described at a conceptual level the optiaization approach and its application to decision aking. The earlior paper also presented a general description of TRICAM, under developnent at that tiae, which rould onable the conparison of transportation systee alternatives on the basis of the optial costs and $f$ iks achievable under each aiternative TRICAM has since been completed and the present paper is intended to dacusent its featurns and capabilities at a detailed level.

\section{INTROOUCTION}

While the 1987 amendent to the Nuclear Waste Policy Act of 1982 (2) gave a new direction to the overall radioactive waste disposal progran, the transportation conponent of the prograe renained virtually unchanged in scope but with incroased attention to potential inpacts, roflecting the reality that howover the rest of the prograe develops, the radioactive waste will need to be transported safoly and cost-affectivaly fron reactors to the disposal site.

Woreover, since the sources of the waste are located predocinantly in the East, and tho permanent disposal facility is likely to bo located in the Wost, the waste will have to be transported across wide sections of the country. Thus, transportation reasins an important component of the waste anagenent syster and one in which there is a great deal of interest anong the public, the Congress, and the utilities.

During the next several years, the OCRIM transportation progras will neod to make significant systes, equipaent, and operational decisions. This will require the evaluation of a wide range of options, fros which the option to be ieplesented will be solected. A rational and dofensible decision-eaking process is critically needed, to ensure that the transportation systen oventually selected ill receive the approval and support of the public, the Congress, and the utilities, all of whon will undoubtedly continue to serutinize the prograe closely.

Thus, it is inportant that the decisions aace in the selection of the transportation systee are sound, and dowonstrably based on dofonsible couparisons of alternatives. Furtheraore, the basis of selection aust give due regard to the two policy objectives of safety and cost-offectiveness. Optimization techniques provide a basis for acconplishing this.

\section{THE OCRIM SYSTEM AS MODEED IN TRICAN}

TRICAM is designed to optiaize the transportation component of the OCRIM systen which consists of the transportation systen, one or more repositories, and possibly monitored rotrievable storage (MRS) or some other interie storage facilities. Although reactors are not part of the OCRIM systes, they are, novortholess, oodeled in TRICAM. The spent fuel to be transported by OCRMM is generated and stored there so inclusion of the reactors is necessary to 'close' the syatea nodaled in TRICAM. Recognizing that the focus in TRICAM is on transportation, however, the costs and risks incurred at the reactors and the other OCRM conponents are nodeled in general teras conpared to transportation costs and risks which aro modelod in considerable detail. 
Figure $I$ is a schenatic representation of the OCRWM systes as nodoled in TRICAM. It depicts, for a single year, the various 'paths' available to nove the SNF from a reactor pool to the repository, which is the permanent disposal site. Fuel discharged fron reactors is placed in a storage pool for cooling. After it has been cooled sufficiently, it can be placod into dry casks storod in the open at the reactor site. The transfor of SNF into the dry casks takes place in the pool. Under existing technology, the SAF would be transforred back into the pool for loading into a transport cask for shipment.

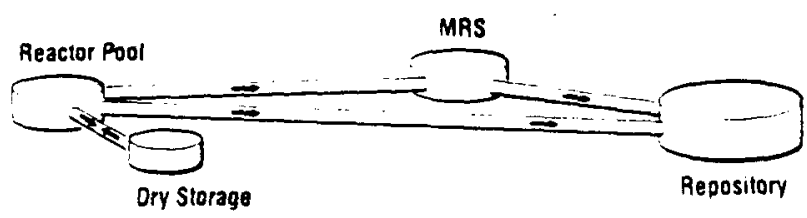

Figure 1. Schematic Representation of Spatial Network Wodolod in TRICAM (single reactor shown)

As an alternative to extended storage at the reactor, SNF can be shipped to the repository directly, or to a temporary storage facility froe which it can be shipped to the final disposal site at a later dato.

Inventories in the reactor pools, in dry storage at reactors, at the MRS, and at the repository provide the year-to-year linkage in TRICAM. The combined spatialtemporal notwork (for a single reactor) way be depicted schenatically as shown in Fig. 2. Clearly, there are innumerable 'paths' through space and tine along which SNF froe a reactor can reach its final destination at the repository. The number of paths run into the aillions for the coeplete notwork containing all the reactors. TRICAM searches for the set of paths that would involve the least risk and/or cost for accomplishing the transfor of the SNF to the repository Obviously, capacity linits at the facilities constrain the solution space.

Table I is a sumary of the risks and costs that are included in TRICAM, indicating the scope of the optisization perforned in TRICAM. As indicated above, TRICAM is designed to optiaizo only the transportation conponent of the OCRM systes, and not the tota I OCRWM systen. Therefore, cortain risks and costs that may be important in a systen-vide optiaization aro specifically excluded fron TRICAM. An exanple of such exeluded risks and costs aro those associated with repository and MRS operations.

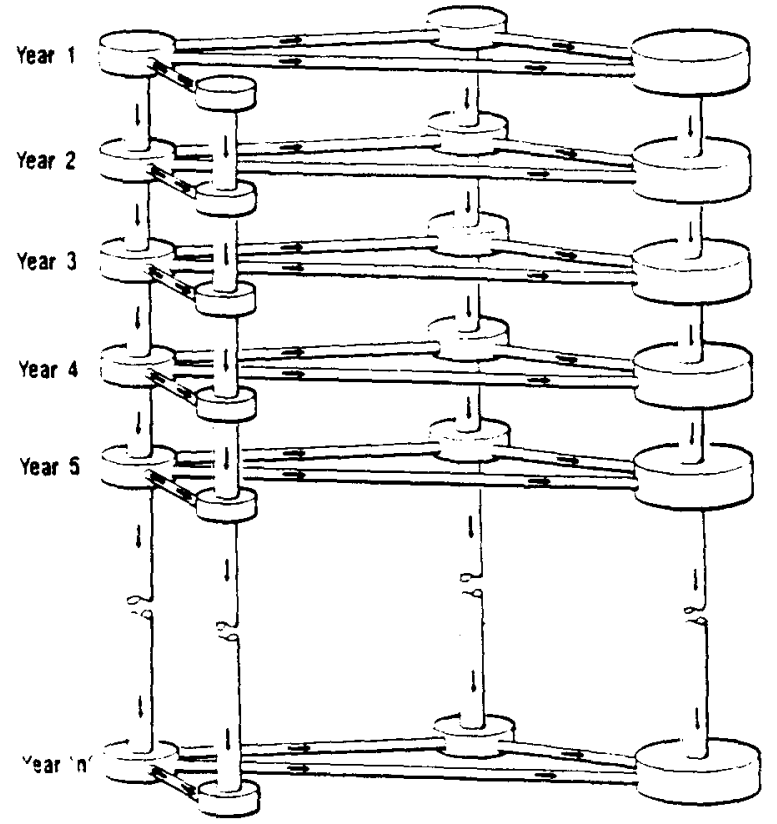

Figure 2. Schenatic Ropresentation of Spatial-Tenporal Network Modelod in TRICNM (single reactor shown)

Table I

Risks and Costs Includod in TRICAM

\section{Risks and Caste Resosciated with} Transportation:

- Loading

- Shipping

- En-route Security

- Cask Ma intenance (cost only)

- Cask Capital Cost (cost only)

- Unloading

Other Risks and Casts it Raxctors:

- Transfors between pool and dey storage casks

- Ory Storage Inventory (cost only)

- Pool Inventory (post-deconissioning costs on $(y)$

Othar Risks and Costs it an vis:

- Placonent in yard storage

- Yard Inventory (cost only)

- Renoval froe yard storago 


\section{TRICAM INTEPFACE WITH OTHER OCRMM CODES}

An important feature of TRICAN is that it utilizes data generated by existing nodels which have beon developed for OCRWI by other contractors. While this approach requires caroful integration of extensive data from several external models, it has the advantage of ensuring consistency across the OCRMY progran and of ninicizing duplication. For exanple, Oak Ridge National Laboratory (ORNL) has generated rail and highway routes for the OCRWM prograe for many years using the INTERLINE (3) and HIGHWAY (4) nodels. ORML is the source of route-specific data in TRICAM. Risk data aro presently obtained fros Argonne National Laboratory (ANL).

Reactor data, comprising reactor nanes, pool eacacitios, locations, and historical and projectod discharges aro obtained froe Battalle's Pacific Northwest Laboratories (PNL), which has had the responsibility of mantaining this database for the OCRWM progran for many years (5). Only the transportation cost data, for which Battollo's office of Transportation Systens 1 Planning (OTSP) has the rosponsibility, is generated intornally. Figure 3
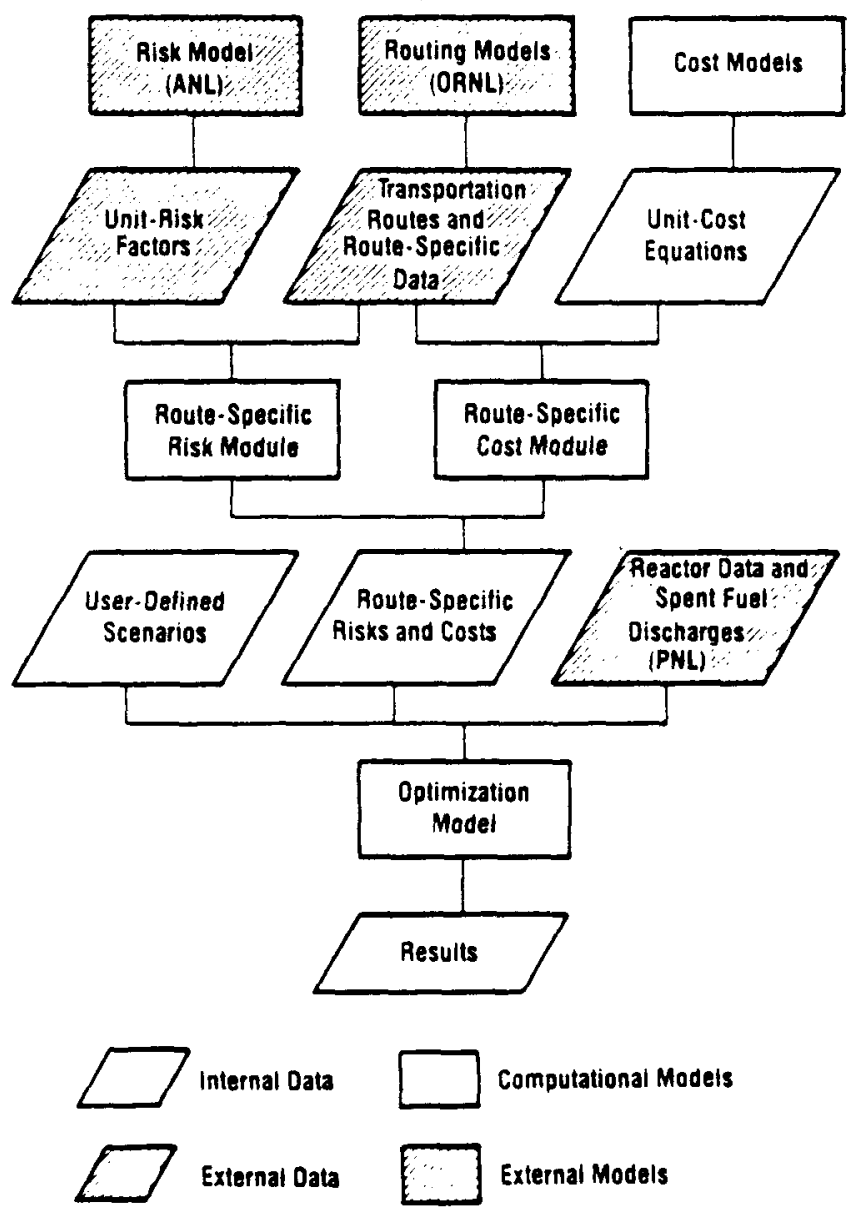

Figure 3. TRICAN's Interfaces with Extornal Codes and Data is a schesatic representation of the interfaces botween these various codols and the integration of the external data in TRICAM.

\section{CODE DESCRIPTION}

In this section, the five codules conprising TRICAN (soe Fig. 4) are described in terns of their input requireaents, the outputs, and their operation. The following section is a more detailed description of TRICNA's menu-driven user interface through which a user dofines the sconario to be analyzed, including the data to be used. The firo sodules in TRICAM are:

- The SCREENER sodulo which is the nenu-driven user interiace used to define the scenario to be analyzod.

- The MAKERSF nodule which calculates the routespesific rigk and cost data for the user-defined scenario.

- The RDEB asdule which condenses the detailed routespecific data provided by ORM. The condensed route database is accessed by MAKERsf.

- The OPTIMIZER sodule" which perfores the opticization and outouts the results of the analysis in a series of tables.

- The CATALOG nodule which is an arehiving systen for the scenarios defined and analyzed using TRICNy. It is TRICNW's tracking and rotrieval systee for all analyses conductod using TRTCAM.

The OPTIMIZER is the only codule that uses large anounts of computer nesory and requires a conputer systen with virtual sesery, like the VAX fasily of computers. All the other TRICAM nodules have been designed for inplenentation on an IBM Porsonal Cosputer. once the scenario is defined and the input files necessary for the OPTIMIZER constructed on a personai computer, control is presently transforrod to a mainframe VAX where the OPTIMIZER is executed. This arrangesent has been found very cost-offective, especially during the developeental stage. It is also convenient froe an application standpoint, since analysts can spocify and sot up a TRICN analysis entiroly on theip personal conputers. TRICAM has boen developed in a mannor to siaplify transfor to a $\mathrm{VAX}$, should potential users express interost an all-VAX version of TRICAN. 


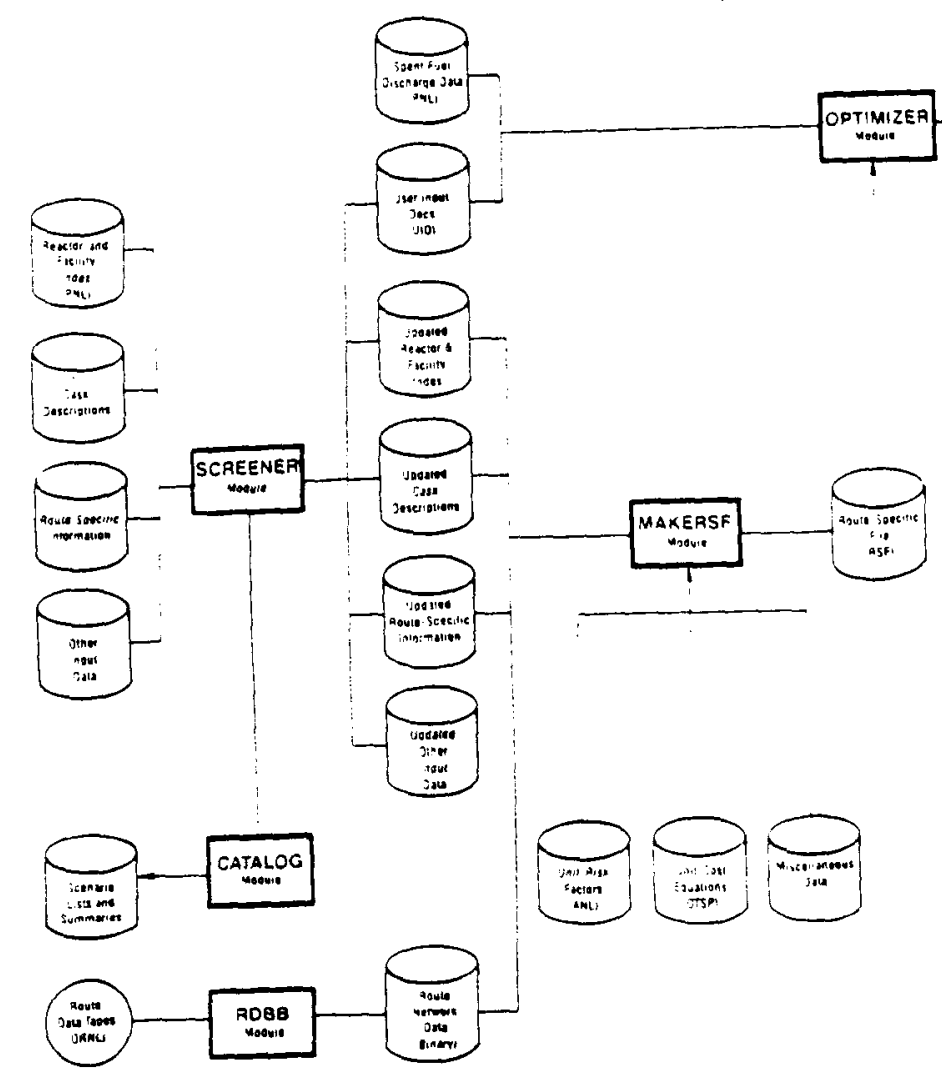

Figure 4. TRICAM Data Flow Structure

\section{The SCREYIER Nodule}

SCREEVER is a senu-drivon oditor through which a user defines the scenario to be analyzed. Recognizing that users will often want to analyze variants of a basic scenario, SCREENER is designed for creating entirely new scenarios, as woll as modifying proviously defined scenarios quickly and conveniently. A conplete TRICAM sconario definition involves specification of the following four sots of data:

- The OCRWM systen, including the OCRMM facilities to be considered, the spent fuel discharge forecast to be used, and the reactors to be included in the scenario,

- The CASK systen,

- The TRANSPORTATION systen, including the origindestination (0/0) natwork, and the arailable nodes, service options, and number of casks per shipnent,

- Other input data, such as the ainimue age of fuel to be transported, the relative weighting of the optiaization criteria, nasely risk and cost, the

period of analysis, and the specification of the level of output dotail desired, ote.

SCREENER generates four output files, corresponding to the scenario defined by the user, one of which is used in the OPTIUIZER codule and the other three in the MAKERSF nodule. These are:

- A User Input Deck (UID) filo. This file contains the user-defined data required to run the OPTIMIZER module.

- A facility and reactor index, used by the WAXERSF module. The index maps individual reactors located at the sane geographic coordinates into a common site index. This appoing is required because whilo dischargo and other data is ractor specific, the transportation reates fron collocated reactors are identical.

- A Routo Sfceific Information (RSI) i ile, used by the MAKEPSF nodule. The default RSI contains separate records for all possible $0 / 0$ pairs for each of the two availablo sodes, rail and truek. The records dofine each $0 / 0$ pair in teras of the following data:

- INIS nubber of the originating reactor

- Identification code for the destination

- Service option, such as regular or dodicated rail service

- Transportation node (truck or rail)

- Nunber of casks per shipuent

- Cask identification code (CASK ID)

- Routo identification codo

- A file containing data on tho cask systoes dof ined by the user in the current scenario. These data aro used in the WAKERSF nodule.

The data flows fro SCREENER to the MAKERSF and sie OPTIMIZER nodules are depictod in Fig. 4. The operations perforaed in the SCREEVER nodulo aro described in further detail in the next section, using samplo screens.

\section{The MAKERSF Nodulo}

The MAKERSF aodule generates, for the specified scenario, a route-specific file (RSF), which is one of the two data files required by the OPTIMIZER nodule The input data used by waKERSF include the following: 
o The three files gonerated by SCREEYER, as described above

- A set of unit-risk factors

- A sot of unit-cost equations

- O/O-specific a leago data generated by RDE8, deseribed below

o A set of aiscallaneous data

Unit-risk factors. Only the route-specific transportation risks, i.e., risks associated with shipping between a given $0 / 0$ pair are used in the MAKERSF. The other risks listed in Table I aro asscciated with activitios at the reactors and the facilities and are incorporated directly in the OPTIMIZER module.

For each of the two modes (truck and rail) eight categories of route-specific risk are required as inputs to the MAKERSF module. Six of theso pertain to radiological exposure and two to non-radiological risks. The routo-specific risk data consist of a sot of Unit Risk Factors (URFs) for each of the ight categories of rigk included. The eight unit-risk factors, denoted URF! to URFa, are elassified into two categories relating to incident-free transportation and accident-related conditions, as shown in Table II.

Table II

Transportation Unit-risk Factors

\begin{tabular}{ll}
$\begin{array}{c}\text { Incident } \\
\text { Accident }\end{array}$ & Related \\
\hline
\end{tabular}

Radiological Risk:

off-Link Exposuro On-Link Exposure

Exposure at Stops

URFI

URF 2

URF3

Ingestion

$-$

URFA

URF5

--

URF8

Non-Radiological Risk:

URF7

URFB specific costs, namely aintenance and capital cost, and the costs associated with activities at the reactors and the facilitios (see Table I), aro incorporated directly in the OPTIMIZER nodule.

Separate cost equations are arailable in the MAKERSF nodule for each of the two sodes. Depending on the service option selected by the user for each $0 / 0$ pair, truck costs can be calculated for shipments in individual trucks or in truck conroys. Likewise, rail costs can be calculated for regular or dedicated service.

Route data. The route data used in the MAKERSF provides a breakdown of the total aileage for the route by the States, road types, and population density categories traversed. The data is in binary fora, and is created by the ROBB sodule (described below) frou the route-data supplied by Oak Ridge. Although an exhaustive set of route data is computed, i.e., for all rail and truck routes fron all origin sites (collocated reactors are conbined into a single origin site) and destinations, MAKERSF operates on a subset of this dats corresponding to the RSI file created for the user-specified scenario.

Miscellaneous Date. The oiscellaneous data file used in WAKERSF contains the following data:

o A table assigning, for each state, the twolve population density categories used in TRICA to one of the three zones (urban, suburban, and rural).

- Average values of population density for each of the twelve zones. It is these average values that are used in calculating the route-specific risk (described below)

- Miscellaneous constants and paraneters, such as the intercepts and slopes for the cost, speed and stoptine equations.

The output of the WAKERSF codule is the Route Specific File (RSF), one of the two files required by the OPTIUIZER nodule. The RSF consists of two parts The first part contains data for each CASK ID, as defined by the user. The second part consists of a series of poute-specific records for each node and route activated in the RSI. For each routa, the RSF contains dats on the per-shipent costs, the per-shipaent risks, round-trip transit tine, nunber of casks per shipsent, and one-way nileage.

WAKERSF generates RSF route records for those RSI records corresponding to the reactors included in the 
analysis. For each such RSI record, WAKERSF performs the following operations:

a. Reads the origin, destination, node, and CASK ID specified in the RSI record.

b. For the given $0 / 0$ pairs, identifies the corresponding site using the site index, and obtains the requisite route-specific aileage data (for the appropriate mode) fron the route database. (At this point, all inforation required to calculate route-specific risks and costs is available in memory)

c. Calls the route-specific risk sub-orogran and calculates the per-shipment risk for the $0 / 0$ pair.

d. Calls the route-specific cost sub-progran and calculates the per-shipment costs for the $0 / 0$ pair

e. Writes the record pertaining to this $0 / 0$ pair to the RSF file.

This process continues until the RSI records are exhausted. At complation, there is ono RSF record for every user-selected $0 / 0$ pair, mode, and CASK ID.

\section{The RDBB Nodule}

The ROBB (route database build eodulo) condenses route-data supplied by ORML and stores it in binary form for use in TRICAN. This akes the input-output (I/O) operations direct and officient.

The input to the RDBB nodule is in the form of nagnetic tapes supplied by ORNL. These tapes contain route data fron all possible origin sites (including generic reactor sites identified by PNL for the lowerand upper-reference spent fuel discharge projections). The route-data describes each link of every route, by the state in which the link falls, the road type, the mode, an urban/rural classification flag, and sundry other characteristics. In addition, the total aileage on each link is provided, and this is further disaggregated into the al iles traversed through aach of the twolve population density categories. This results in an extreacly large data base, which would be diffieult to anipulate in its recoived form.

The link-by-link data supplied by ORNL is intended to support other OTSP activitios other than TRICAM analyses, such as ap goneration. A|| TRICAM calculations can be perforaed if the route nileage data is available by state, road type, and population density. Therefore, the extensive ORNL data is aggregated by state, road type, and population density, and translated into two binary files. The first filo contains a ultidimensional tablo that holds the address of the data stored in the second file. The second file contains the actual ileage data.

\section{The OPTIMIZER Nodule}

The algorith used to perfora the actual optiazation in TRICAM is NETFLD, which is a network optiazation nodel that has been documented in the literature (7). The inputs to the OPTIMIZER are:

- The RSF file generated by MAKERSF

- The UID file generated by SCREENER

- The reactor data and spent-fuel discharges provided by PNL. These data are updated annually by PNL The latest of these series (5) is incorporated in TRICAN eurently, and will be replacod then updated data becomes arailablo.

vith this data, the OPTIMIZER conputes a solution that aniaizes the value of the objective function wich can range from pure-cost to oure-risk, or any weighted combination in bacwoen. A discussion of the objective function in inital is providad in the earlier paper (1) The solution includes, in addition to the optimal risks and costs, information on the inventories at the reactors and the facilitios in each yoar, annual shipent quantities, the transportation modes, nodal split, and cask fleet aix. Through the SCREENER nodule, the user can oither obtain this data in the forn of annual suanary tables or on a reactor-by-reactor basis. Que to liaitations on anuscript length, a detailed description of the various tables generated by TRICAN is not provided here. Instead, interested readers aro urged to write to the authors who would be happy to supply a conplote samplo set of the output tables.

\section{The CATALOG Nodule}

CATNDO is TRICAN's scenario archiving and tracking systen that, in the authors view, ill prove invaluable to users over the long pun. In the OCRMM progras retrievability and duplicability of results is an iaportant consideration. In that sense, CATALOC serves as a 'QA manager' for analyses conducted using TRICAN.

This modulo collects and catalogs information describing the TRICAM sconarios. Once a scenario has been defined, the user can olect to catalog it. This action causes CATALOG to pronpt tho user for a brief description characterizing the scenario which is stored along with the scenario nase in a text file.

This toxt file is the single output of the CATALOC codule. Associated with this scenario, CATALOG keeps all the input files constructed by the user for this 
particular scenario, including the UID which defines the reactor and spent fuel dischargo data used in the scenario.

\section{TRICAN USER-INTERFACE}

One of the prine design objectives for TRICAM was to expand the user base as wuch as possible. This has been acconplished by designing a cenu-driven userfriendly interface for TRICAM, roferred to as the SCREENER nodulo. Sone codes developed for OCRIM in the past require oxtensive dato input in a eanner that is quite eunbersone. Thus, few people outside the code development teans have found these codes practical to use. By azking its codes accessible and user-friendly, OCRWM can facilitate the use of comon data and nodels by its various contractors, as woll as other interested groups. In the author's view, this will ongender confidence in OCRMY's analyses and facilitate

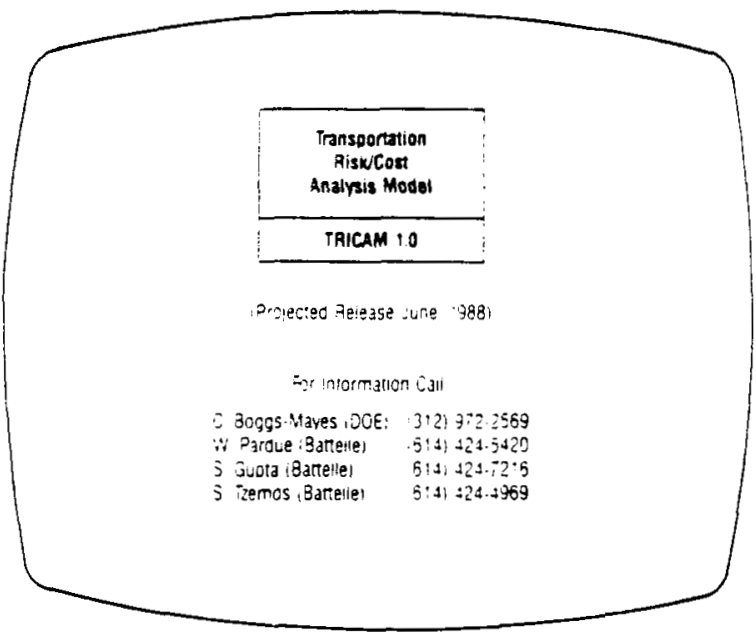

Figure 5. Weicome Screen

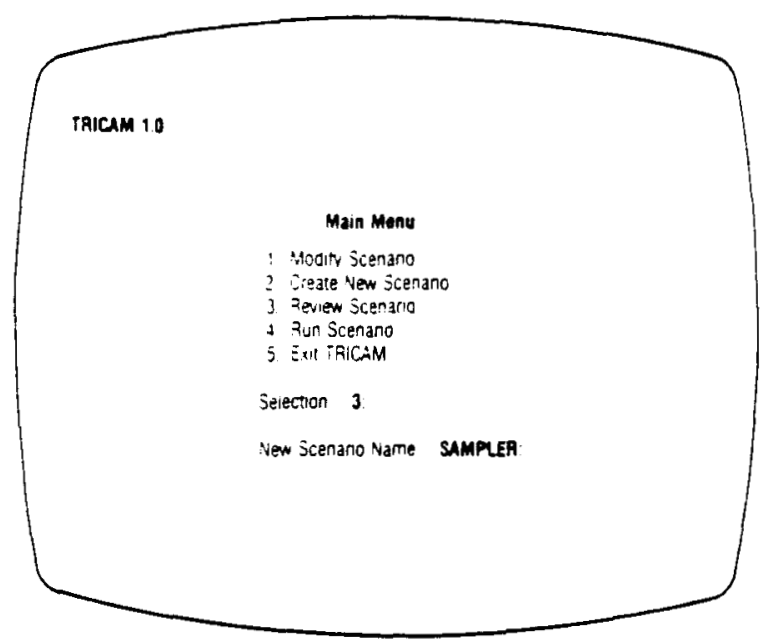

Figure 6. Main-Menu reconciliation of any parallel analysos that different groups aay perfora.

The SCREENER sodule has been described in general terss above. In this section, the reader is 'walked' through an exenplary session, using exanples of sone of the cenus available to specify a TRICAM run.

After the wolcaeo scroen (Fig. 5), the wain menu (Fig. 8) appears. This seroen allows the user to oodify a proviously dofined scenario, generate a now scenario, or roview any scenario. In the exasple shown on Fig. 3 . the user has chosen to create a new sconario naned 'SAMPLER'. When the 'Croate New Scenario' option is solected, the scroens cone up with the set of default data wich represents the 'roference' transportation systen.

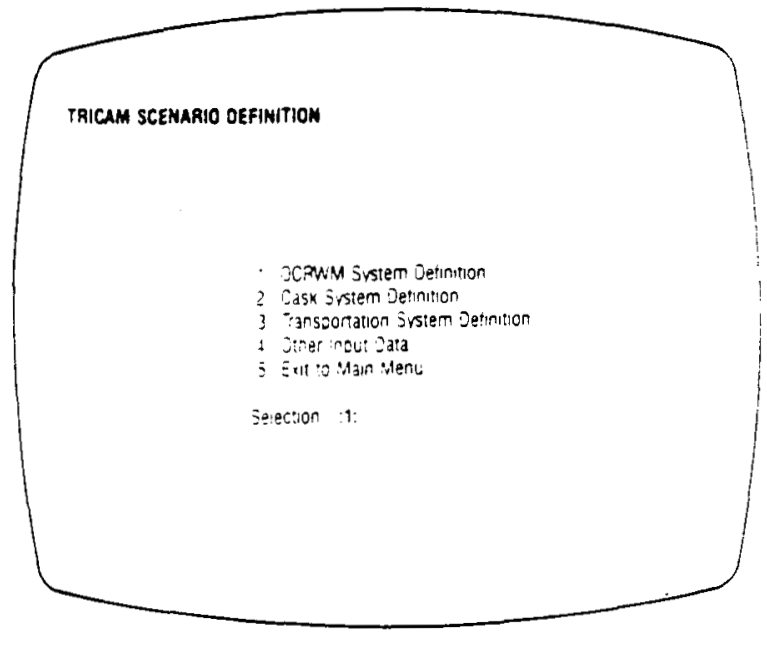

Figure 7. Scenario Definition Process

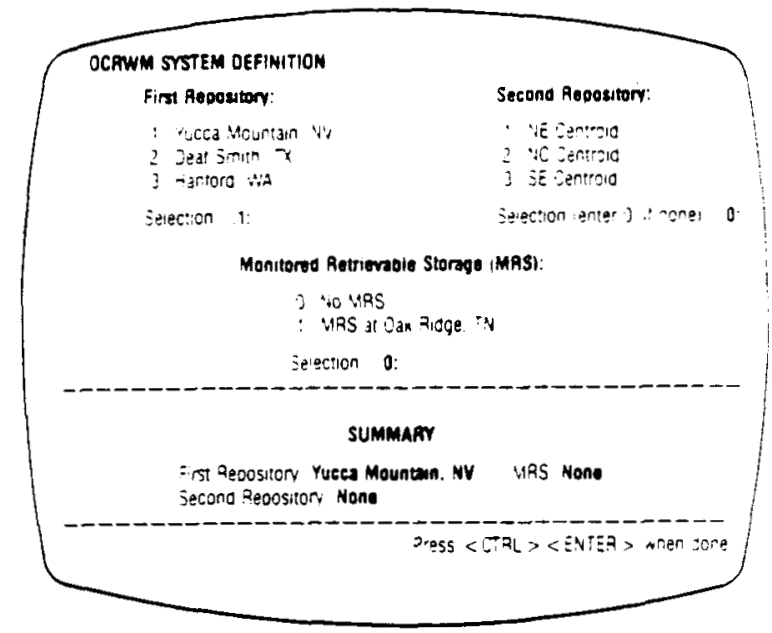

Figure 8. OCRWM Srrem Detinition: Facilities 
The next scroen starts the sconario definition process (Fig. 7). The scenario dofinition is complete only when all four options have been exercisod. Figs. 8 through 10 aro the throe ain screens for defining the OCRWM systea. With these scroens, the user specifies the facilities and ractors to be included, and the spent fuel discharge foracast to be used in the analysis. The cask systen is defined with the screen shown in Fig. 11. The transportation systen is defined through two screens (Figs. 12, 13), which aro ropeated for every destination included in the scenario. The first screen allows the user to set default values for type of service, number of casks per shipeent, and the CASK ID. The second screen cones up with these dofault values, which the user can change on a reactor-byreactor basis, if necessary.

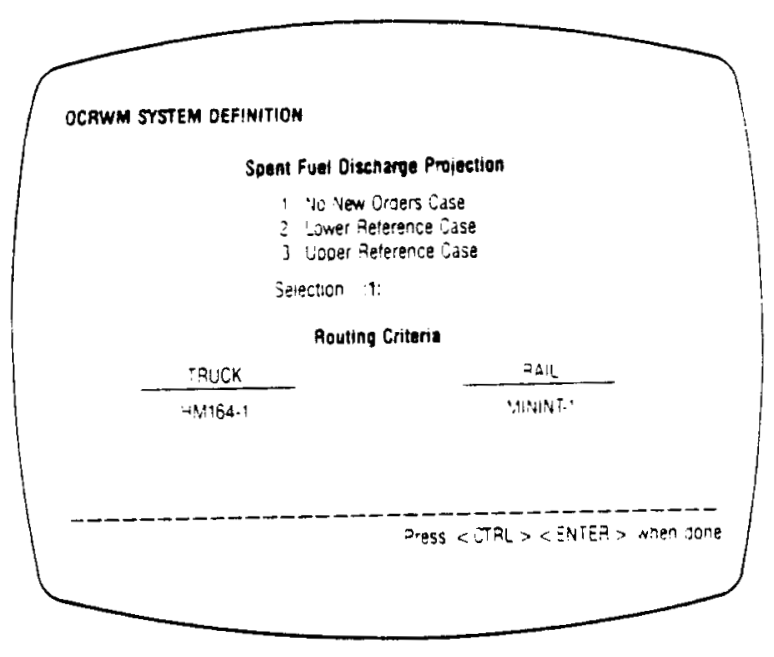

Figure 9. OCAWM Syeem Oefinition: Soent Fuel Discrarge Forocast

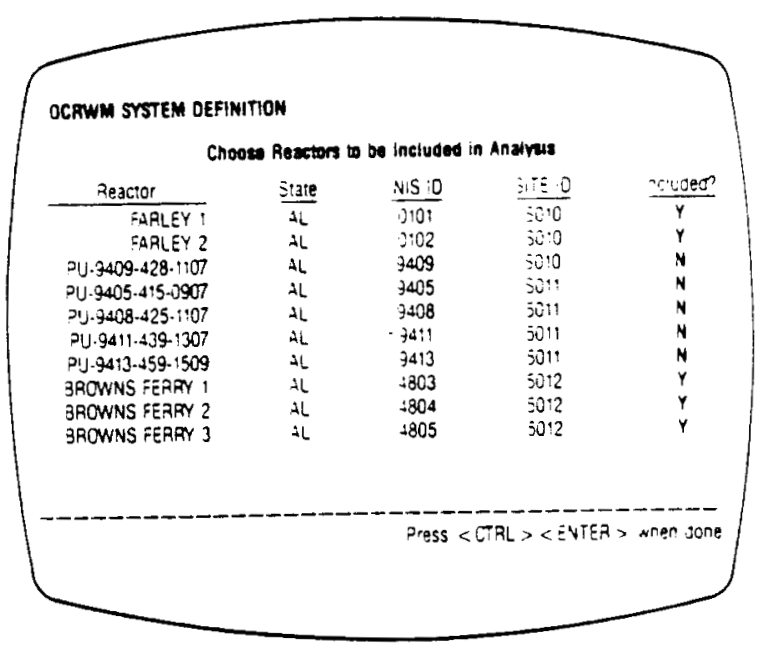

Figure 10. OCRWM Sytem Definition: Reactors Included

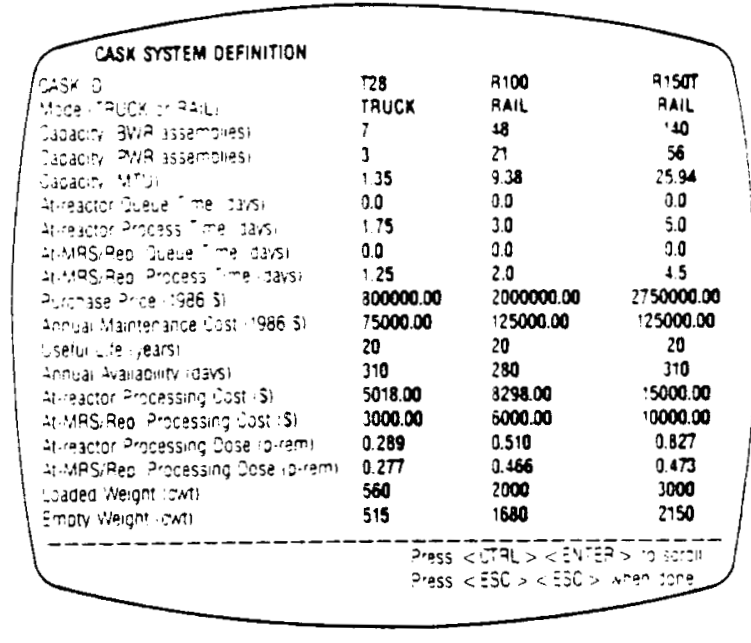

Figure 11, Cask System Detinition

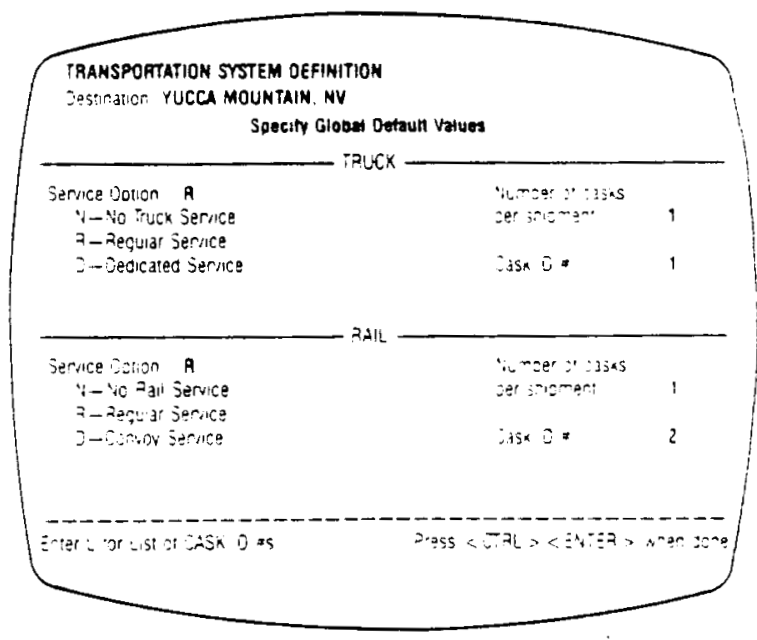

Figure 12. Trangportation System Definition: Global Defaults

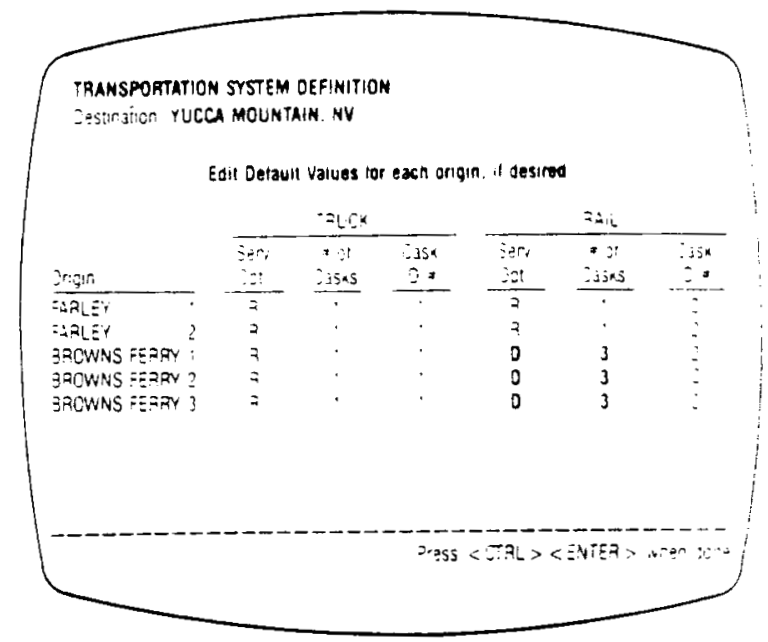

Figure 13. Transportation System Delinition oy Individual Ongin-Desination 
Finally, the screen shown in Fig. 14 is used to specify the reasining input data to conplete the scenario and define the run paramoters, such as the nininua age of fuel to be transported, cost/risk weighting factors, output tables, otc. Once this screen has been conpleted, the user is returned to the main menu. The user ean reviou the scenario and/or seloct the 'Run Scenario' option. This executes the MAKERSF nodule, which propares the input files required to execute the OPTIMIZER nodule on the VAX computer.

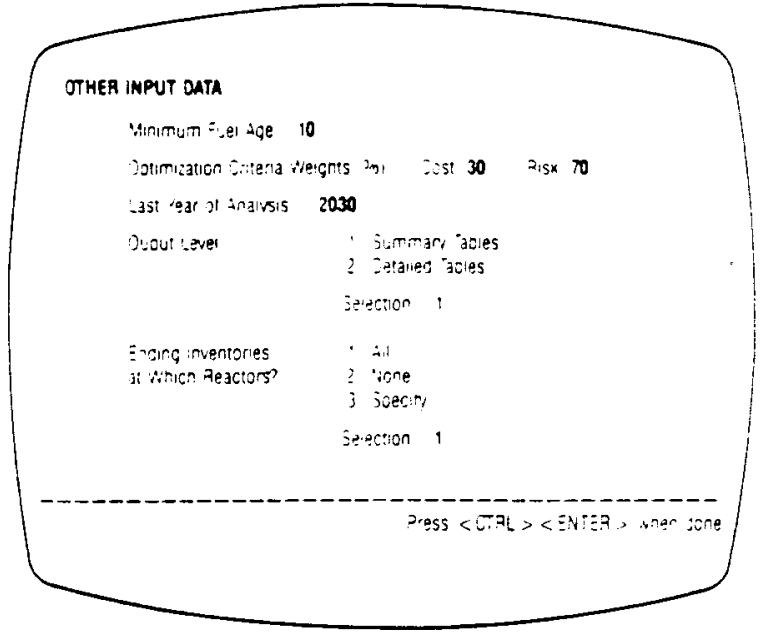

Figure 14. Other Input Parameters

Notes:

a. This module was developed for OTSP by Battello's Pacific Northwest Laboratories.

b. In the current version of TRICAN, optinization can be perforad only for radiological risk. To conbine radiological risk (measured in porson-ron) with non-padiological risks (measured in fatalitios), the forner needs to be converted to fatalities. While this transforation is siaple, presently the pisks not directly associated with transportation (see Table I) are hardcoded in units of person-ree. Thus, soae (ninor) recoding is required to enable optioization on conbined risk. This capability ill be provided in TRICAM if it is found to be of interest to users.

\section{REEREHCES}

1. Gupta, S., D.G. Dippold, M.R. Shay, C. BoggsMayes, (1987), 'Nuclear Naste Transportation: An Optimization Model," Proceedings of the Symposiun on Waste Manageaent, Tucson, AZ, Warch 1-5, 1987.

2. Nuclear Waste Policy Auenduents Act of 1987 (Decenber, 1987).

3. Poterson, 8.E., (1983), INTERLINE, A Rail road Routing Model: Progran Description and User's Manual, Oak Ridge National Laboratory, Oak Ridge, TN. (ORNL/TM-8944).

4. Joy, D.S., P.E. Johnson, and S.M. Gibson, (1982), HICHIAY, A Transportation Routing Wodel: Progran Description and Usor's Manual, Oak Ridge National Laboratory, Oak Ridgo, TN. (ORNL/TM-8149).
5. R.C. Malling, ot.al. (1988), Reactor Specific Soent Fuel Dischargo Projections: 1987-2829, Pacific Northwest Laboratories, Richland, MA. (PNL-6430, forthconing)

B. Madsen, M.M., J.M. Taylor, and R.M. Ostemeyer, (1986), RAOTRAN III, Sandia National Laboratories, Albuquerque, NM. (SANO84-8036).

7. J.L. Kennington and R.Y. Helgason, (1986), Algorithms for Notwork Programing, John iley Sons, New York, NY 